\title{
The signaling function of artificial ornamentation in humans
}

\author{
Dissertation \\ zur Erlangung des Doktorgrades \\ der Mathematisch-Naturwissenschaftlichen Fakultäten \\ der Georg-August-Universität zu Göttingen
}

vorgelegt von

Silke Wohlrab

aus Ingolstadt 
D 7

Referent: $\quad$ Peter M. Kappeler

Korreferent: Henning Gibbons

Tag der mündlichen Prüfung: $\quad 31.10 .2007$ 


\section{Contents}

General InTRODUCTION

CHAPTER 1

Menschlicher Körperschmuck aus evolutionärer Perspektive - Diversität und Funktionen von Tätowierungen, Piercings und Skarifizierungen

Chapter 2

Modifying the body - motivations for getting tattooed and pierced

ChAPTER 3

Visual attention to plain and ornamented human bodies: An eye-tracking study

Chapter 4

Differences in personality characteristics between body-modified and nonmodified individuals: Associations with individual personality traits and their possible evolutionary implications

Chapter 5

Human body modification: testing the signaling quality of tattoos

Chapter 6

Differences in personality attributions towards tattooed and non-tattooed virtual human characters

Conclusions

SUMMARY

ZUSAMMENFASSUNG

AcKNOWLEDGEMENTS

REFERENCES 


\section{General introduction}

Mate choice and competition for mates are the two main mechanisms of sexual selection (Andersson, 1994; Bateman, 1948; Darwin, 1871). Both derive from an asymmetry in parental investment (Trivers, 1972). Considering classic sex roles, females are the limiting resource due to a lower reproductive potential caused by anisogamy, so that males compete for access to choosy females (Trivers, 1972; Kokko \& Monaghan, 2001). However, female competition and male mate choice have been observed as well (Drickamer, Gowaty \& Holmes, 2000; Moore, Gowaty; Wallin \& Moore, 2001; Gowaty, 2004). Sexual selection operates on traits that influence reproductive success (Clutton-Brock, 2004; Darwin, 1871), including visual or acoustic signals displaying information about the bearers' condition (Fisher, 1930; Grafen, 1990; Kokko, Brooks, McNamara \& Houston, 2002; Zuk, 1991). Such ornaments are widely spread in the animal kingdom, such as antlers in deer (Packer, 1983), colorful feather displays in birds (Petrie \& Halliday 1994; Dunn, Whittingham \& Pitcher, 2001) or extravagant coloration in numerous fish (Milinski \& Bakker, 1990; Amundsen \& Forsgren, 2001).

Two explanations for the evolution of ornaments are being discussed. The first is 'Fisher's runaway hypothesis', which states that arbitrary traits are reinforced by female mate choice due to a genetic relation of preference and trait (Fisher, 1930). A second approach, the 'good genes model', assumes that ornamental traits are not arbitrary but indicate genetic quality of their bearer. Because the genotype cannot be assessed directly, the honesty of signals has to be warranted by the costs of the traits (Grafen, 1990). Accordingly, the handicap principle states that only individuals in good condition are able to cope with the costs involved in the establishment and maintenance of such ornaments (Zahavi, 1975). An important aspect of condition is parasite resistance, which enables individuals to invest in elaborate ornaments (Folstad \& Carter, 1992; Hamilton \& Zuk, 1982; Møller \& Petrie, 2001). It has been proposed that carotinoid-based coloration in birds might signal immunocompetence (Blount, Metcalfe, Birkhead \& Surai, 2003; McGraw \& Ardia, 2003; McCraw \& Hill, 2000). Thus the coloration resembles an ornament that signals the quality of the bearer as a potential mate. 
The human body also represents a multiple visual ornament that signals quality (Thornhill \& Grammer, 1999). Symmetry of bilateral traits, for example, mirrors the ability to cope with environmental and genetic stressors during ontogeny (Van Valen, 1962; Thornhill \& Møller, 1997). The ability to cope with those stressors is manifested in fluctuating asymmetry, which therefore is supposed to be a reliable indicator of good health and thus phenotypic quality (Thornhill \& Møller, 1997). Physical condition is also closely linked to sex hormones due to their immunosuppressive effect and their negative influence on symmetry in high concentrations (Dabbs \& Dabbs, 2000; Fink, Manning, Neave \& Grammer, 2004; Service, 1998). Thus, symmetrical traits or traits influenced by sex hormones are assessed in mate choice and used in the evaluation of attractiveness (Gangestad \& Simpson, 2000; Fink \& Penton-Voak, 2002). Thereof derived the concept of Darwinian aesthetics, which states that basic human beauty standards reflect evolutionary adaptations for choosing mates of good condition (Grammer, Fink, Møller \& Thornhill, 2003; Voland \& Grammer, 2003).

Previous evolutionary studies on human physical attractiveness have concentrated on morphological traits. Little considered were artificial ornaments as well as the role of skin in beauty assessment. In early works, Morris (1967) and Symons (1979) alluded to a role of skin and skin alterations in the perception of physical attractiveness, but both studies were not based on empirical data. Furthermore, it has been shown that skin color and texture affect attractiveness ratings such that paler, more homogeneous skin is preferred (Darwin, 1871; Fink, Grammer \& Thornhill, 2001; Frost, 1988; Jones, Little, Feinberg, Penton-Voak, Tiddeman \& Perret, 2004; Van den Berghe \& Frost, 1986). Additionally, Russel (2003) described luminance as a factor influencing the appearance of faces regarding femininity and masculinity. Roberts and colleagues (2005) reported a relationship between skin attractiveness ratings and the major histocompatibility complex (MHC), such that skin of men that were heterozygous at three loci of the MHC was rated more attractive than skin of men that were homozygous in these loci. Thus, skin seems to provide information about physical condition and individuals are capable of perceiving variations in skin conditions. 
Consequently, artificial alterations of the skin might play a role in the assessment of human attractiveness. Morris (1985) described diverse alterations of bodily features in various cultures and times that were employed to enhance attractiveness. He illustrated modern fashion trends concerning hair and body shape, but also included more invasive practices, such as neck elongations of women in the Burmese tribe Padaung and various alterations of the skin. The latter comprise different body modification techniques such as scarifications, branding, tattooing and body piercing. Those techniques have a long history and have been employed in various cultures (Gilbert, 2001; Rubin, 1988a). Especially tattoos and body piercings have been of great interest to some in ethnology, sociology and psychology.

Ethnologists described various forms and functions of body modification in different cultures. Scarifications, tattooing and body piercings were of ritual significance, marking rites of passage (e.g. Faris, 1988; Jonaitis, 1988; Wilbert, 1994), symbolizing status (Gathercole, 1988, Gilbert, 2001; Gritton, 1988), enhancing physical attractiveness (Berns, 1988; Camphausen, 1997; Gilbert, 2001), but were also used to mark criminals and outlaws (Gilbert, 2001; McCallum, 1988). In recent history, Western tattoos and body piercings remained a subcultural, unconventional practice until they experienced a 'renaissance' in the 1980s (DeMello, 2000; Rubin, 1988a). Nowadays they are considered part of the mainstream culture, although negative stigmatization prevails (DeMello, 2000; Pitts, 1999).

Many sociologists focused on motivational aspects, why people achieve body modifications and what this implies. They often concentrated on particular peer groups, such as the so-called 'neo primitives' (Atkinson \& Young, 2001; Vale \& Juno, 1989) or feminists (Atkinson, 2002; Jeffreys, 2000). They assigned body modifications a self-healing function (Fisher, 2002; Sweetman, 1999), a way to reclaim the body (Atkinson, 2002; Jeffreys, 2000), to manifest experiences (Millner \& Eichold, 2001; Vail, 1999) and to create a self-identity (Greif, Hewitt \& Armstrong, 1999; Schildkrout, 2004, Stirn, 2004a). Others claimed tattoos and body piercings to be mere fashion accessories in postmodern society (Craik, 1994; Steele, 1996). 
The psychological line of studies concentrated on the relationship between tattoos or body piercings and deviant behavior. Tattooing and body piercing were associated with risktaking behaviors, such as smoking, alcohol and drug use (Drews, Allison \& Probst, 2000; Forbes, 2001; Makkai \& Allister, 2001; Roberts, Auinger \& Ryan 2004), criminality (Palermo, 2004) and personality disorders (Carroll \& Anderson, 2002; Romans, Martin, Morris \& Harrison, 1998). Recent studies examined the relation of body modification and rather basic personality dimensions, considering that body modification entered mainstream culture and is gradually dissociating from old stigmatizations (Reyntjens, 2002; Stirn, 2004b; Wohlrab, Stahl, Rammsayer \& Kappeler, in press).

Finally, body modifications have also been investigated from a biological perspective. Two cross-cultural studies proposed a signaling function of body modification in sexual selection. Ludvico and Kurland (1995) found that the prevalence of scarifications is positively related to polygyny, which they used as a proxy for female choice. The authors concluded that body modifications are non-adaptive Fisherian signals in sexual selection. In contrast, the second study attributed body modifications an adaptive significance as signals in sexual selection due to a positive correlation between female scarifications and pathogen load. Thus, invasive body modifications represent handicap signals (Singh \& Bronstad, 1997). However, because tattoos and piercings are not heritable, an adaptive explanation bears some constraints. Sexual selection theory predicts, "culturally augmented sexual signals may be favored when they represent a novelty, and that they should be favored when they exist in a somewhat exaggerated form" (Low, 1979).

Therefore, I assumed a signaling function of modern tattoos (and body piercings) in human sexual selection. The present thesis provides results from various studies examining the signaling function of tattoos (and body piercings) and is divided into six chapters. In Chapter 1, I review current explanations for appearance and function of body ornaments, accumulating evidence for a biological significance of body modification. Chapter 2 illuminates the motivations of tattooees and piercees for obtaining their body modification. Chapter 3 investigates whether tattoos attract visual attention and whether differential attention towards other skin alterations or fashion accessories supports a biological signaling value. In Chapter 4 I report a group characterization of body-modified individuals with 
respect to demographic traits as well as in five personality dimensions, assuming that differences compared to a non-modified control group reflect potential signaling values. Chapter 5 and 6 focus on the receiver's perspective by examining differential perception of tattooed and non-tattooed stimuli on different attributes. Specifically, Chapter 5 covers attributes of biological significance in the mating context, whereas Chapter 6 concentrates on psychological differences and signaling value. In the following I provide more detailed descriptions of the single chapters as well as their context and relevance for the general research question.

Body modifications such as tattoos and body piercings exist in many cultures and show a great diversity in peculiarities as well as functions. However, some functional aspects, which I review in Chapter 1, seem to be similar across cultures as well as over time. From early occurrences up to today's practices functional similarities such as signaling status, strength or group affiliations occur (DeMello, 2000; Gilbert, 2001). Body modifications continue to be used in rites of passage, they are supposed to create self-identity and possess aesthetic value (Camphausen, 1997; Gilbert, 2001; Sweetman, 1999). Considering the substantial health risks associated with body modification, the above-mentioned functions do not sufficiently account for the continuity of body modifications throughout history. Evolutionary psychologists explain aesthetic preferences by ascribing attractive bodily features a signaling value of biological fitness and thus quality as a potential mate (Grammer, Fink, Møller \& Thornhill, 2003). It therefore seems intuitive to explain the prevalence of body modifications and their aesthetic appeal by mechanisms of sexual selection.

Self-reported motivations for the acquisition of tattoos and piercings support a function of body modification in the mating context. In Chapter 2 I review motivations of people for obtaining body modifications. Although motivations are various, I was able to define ten broad categories of main motivational aspects. These categories are 'beauty, art and fashion', 'individuality', 'personal narrative', 'physical endurance', group affiliations and commitment', 'resistance', 'spirituality and cultural tradition', 'addiction', 'sexual motivation', and 'no specific reason'. The number of studies found for each motivational category reflects the relative importance of the different motivations: most frequently 
mentioned in the literature is physical embellishment as well as the creation of self-identity, which might thus be considered as predominant motivations for people to get tattooed and / or pierced. Especially the assessment of beauty and attractiveness are major criteria in mate choice (Grammer et al., 2003), providing further support to examine the prevalence of body modification with respect to sexual selection, specifically mate choice.

To investigate whether tattoos actually fulfill the prerequisites to act as signals and to investigate their signaling value, I conducted an eye-tracking study, measuring visual attention to artificial human bodies - further on referred to as stimuli - under different conditions (Chapter 3). Conditions comprised plain stimuli as control, tattooed stimuli, stimuli with natural skin alterations like scars and stimuli with other fashion accessories. I hypothesized that stimuli with tattoos, scars or accessories would draw more attention than plain stimuli. Furthermore, if tattoos had a specific value of signaling mate quality, I expected tattoos to attract more inter-sexual attention than scars or accessories. Results of this study supported the above predictions. I found that generally plain stimuli received the least attention, whereas tattooed stimuli attracted significantly more attention than all other conditions. Additionally, I revealed intersexual effects such that male participants paid more attention to tattooed as well as scarred stimuli. Also female stimuli were looked at longer in all but the scarred condition. Thus, a signaling value of tattoos in the context of sexual selection is consistent with these results but requires further examination.

To provide a basis for following investigations, I conducted a questionnaire survey to characterize the group of today's body modifiers (Chapter 4). I compared a broad sample of body-modified individuals with a non-modified control group in demographic and personality traits. The latter comprised an inventory of five basic personality dimensions (Big Five Inventory; Lang, Luedtke \& Asendorpf, 2001), an instrument to assess psychological sex roles (Bem Sex Role Inventory, Bem, 1974), a tool to record the attitude towards the own physical appearance (Fragebogen zur Beurteilung des eigenen Körpers; Strauß \& RichterAppelt, 1996), an inventory to evaluate mating strategies (Sociosexual Orientation Inventory; Simpson, 1998) and lastly an instrument to assess the trait sensation seeking (Sensation Seeking Scale; Zuckerman, 1979). Body-modified individuals did not differ from the nonmodified control group in demographic parameters but appeared less agreeable, more eager to 
accentuate their physical appearance, scored higher in sensation seeking and exhibited a more unrestricted, promiscuous mating strategy. Results are discussed in the light of a potential signaling function of modern body modification in social interactions, particularly in the mating context.

Chapter 5 and Chapter 6 deal with the perception of tattoos as signals. Previous chapters were concerned with the sender's perspective, but besides the sender the alteration of behavior in the receiver is critical for the signaling value (Maynard Smith \& Harper, 1995). First I investigated, whether tattoos possess a biological signaling quality as suggested by theory of sexual selection (Chapter 5). Based on sex-specific mate choice criteria (Buss, 1989; Buss \& Schmitt, 1993), I predicted variation in the perception of attractiveness, aggression, dominance, health and masculinity or femininity for a signaling value in mate choice such that tattooed stimuli would be rated higher on attractiveness, health, dominance and femininity or masculinity respectively and lower on aggression. Specifically, I expected that tattooed female stimuli were specifically rated higher on attractiveness, health and femininity by male raters as well as tattooed male stimuli were specifically rated higher on attractiveness, health, dominance and masculinity but lower on aggression by female raters. I tested these predictions with a rating study of tattooed and non-tattooed virtual human bodies and found that tattooed female bodies were rated less healthy, whereas male tattooed bodies were rated more dominant. The results were neither sufficient nor consistent enough to prove a function of tattoos in signaling mate quality; findings in female stimuli even contradict the hypothesis. However, hypotheses were generated expecting a signaling value in mate quality. Due to the characteristics of modern tattoos, results suggest that tattoos might signal identity rather than quality (Dale, Lank \& Reeve, 2001).

I conducted a further experiment to investigate whether previously revealed selfreported personality differences between body modified and non-modified individuals are perceived by others (Chapter 6). Based on results of the study presented in Chapter 4, I expected tattooed bodies to be perceived as higher sensation seekers as well as more unrestricted in their sociosexuality. This was indeed the case, but only in male stimuli. Tattooed males were perceived as more adventurous, more open to new experiences, less inhibited and lower in boredom susceptibility. Furthermore they were rated to have more 
different sexual partners than the same stimuli without a tattoo. Sensation seeking and sociosexuality reflect basic attitudes and values of a human personality (Gangestad \& Simpson, 2000; Litle \& Zuckerman, 1986; Zuckerman, 1983; Zuckerman \& Litle, 1986), and both traits have been shown to be relevant in mate choice. 


\section{Chapter 1}

\section{Menschlicher Körperschmuck aus evolutionärer Perspektive - Diversität} und Funktionen von Tätowierungen, Piercings und Skarifizierungen

[Human body ornamentation from an evolutionary perspective - diversity and functions of tattoos, piercings and scarifications]

Silke Wohlrab*, Bernhard Fink* \& Peter M. Kappeler*o

* Abteilung Soziobiologie / Anthropologie der Universität Göttingen, Deutschland

- Abteilung Verhaltensökologie und Soziobiologie, Deutsches Primatenzentrum, Göttingen, Deutschland 


\title{
Zusammenfassung
}

Tätowierungen, Piercings und Skarifizierungen haben eine lange Geschichte und sind in vielen Kulturen zu finden. In dieser Arbeit fassen wir die gängigsten Erklärungen für diese Körpermodifikationen zusammen. Obwohl ihre Ausprägungen und Funktionen vielfältig und zwischen Kulturen und Zeitaltern vergleichbar sind, gibt es keine einheitlichen ethnologischen Erklärungen für deren Existenz und Diversität. Aus biologischer Sicht ist der Erhalt solcher Merkmale, der mit Kosten in Form von Gesundheitsrisiken verbunden ist, bislang wenig untersucht. In einigen Studien wurden Mechanismen der sexuellen Selektion für das Vorkommen und die Ausprägungen dieses invasiven Körperschmucks mit verantwortlich gemacht. Mittlerweile verdichten sich die Hinweise darauf, dass ähnliche Mechanismen auch in modernen, westlichen Kulturen wirken, so dass die zunehmende Popularität von Körperschmuck sich offenbar auch teilweise auf grundlegende biologische Determinanten des menschlichen Verhaltens zurückführen lässt.

\begin{abstract}
Practices of tattooing, body piercing and scarification have a long history and can be found in many cultures. In this paper, we review current explanations for these body modifications. Although their appearance and functions are highly diverse and comparable across cultures and time, there are no comprehensive ethnological explanations for their existence and diversity. From a biological point of view, the preservation of such costly signals (with respect to associated health risks) has received little attention. Some studies have attributed the prevalence and appearance of invasive body ornaments to sexual selection. Evidence that similar mechanisms might also act in modern Western societies is accumulating, so that its recently increasing popularity may partly be also attributable to biological determinants of human behavior.
\end{abstract}




\section{Einleitung}

Praktiken des Tätowierens, Piercens und des Skarifizierens können in der menschlichen Geschichte mehr als 5000 Jahre zurückverfolgt werden. Der Tiroler Gletschermann „Ötzi“, eine 1991 im Gletschereis entdeckte 5200 Jahre alte Mumie, erregte nicht nur durch sein beträchtliches Alter, sondern auch durch den Besitz von 15 gut erhaltenen Tätowierungen Aufsehen, welchen vermutlich eine therapeutische Motivation zugrunde lag (Dorfer \& Moser, 1998). Mit 4600 Jahren waren die Funde dreier ägyptischer Mumien die bis dahin ältesten Nachweise für die Existenz von Tätowierungen gewesen (Bianchi, 1988). Auch in Sibirien und Südamerika wurden prähistorische Mumien mit Tattoos entdeckt, die offensichtlich dekorative Zwecke erfüllten (Dorfer et al., 1999). Piercingschmuck wurde in Grabmälern geborgen; Hinweise für Skarifizierungen fand man vornehmlich auf prähistorischen Statuen (Rubin, 1988a). Neben diesen historischen Funden sind Tätowierungen, Piercings und Skarifizierungen bis heute bei Naturvölkern in Ozeanien, Afrika, Asien und Amerika verbreitet, wobei Variabilität in Gestalt und Funktion des invasiven Körperschmucks bemerkenswert sind. In diesem Aufsatz versuchen wir, diese Variabilität zu analysieren und grundlegende Funktionen zu identifizieren.

\section{Tätowierungen}

Ein Tattoo ist als Bild, das mit Farbpigmenten in die Haut gezeichnet wird, definiert. Bereits bei Naturvölkern und $\mathrm{zu}$ früheren Zeiten wurde meist mit nadelförmigem Gerät punktiert. Heute wird in westlichen Gesellschaften dafür in der Regel eine Tätowiermaschine benutzt, die durch Vibration eine oder mehrere Nadeln in die oberste Hautschicht sticht. Am wohl bekanntesten sind die Tätowierungen der neuseeländischen Maoris. Ihre meist geometrische Gesichts-Mokos weichen von der üblichen Methode ab und ähneln eher Schnitzereien (Gathercole, 1988). Die Tätowierungen unterschieden sich zwischen den Geschlechtern, und sowohl die Anzahl als auch die Qualität waren statusabhängig. Männer erschienen durch ihre Mokos grimmiger und wilder im Kampf, gleichzeitig machte es sie für Frauen attraktiver (Gilbert, 2001). Dies könnte als Hinweis auf eine mögliche biologische Funktion der Tätowierungen gewertet werden. Manche Motive kennzeichneten auch die Stammeszugehörigkeit; dies war allerdings keine universelle Funktion. Weiterhin wurden 
Mokos in Neuseeland als Verkörperung der maorischen Kultur angesehen und besaßen mythologische Bedeutung (Gathercole, 1988; Gilbert, 2001). Tätowierungen waren auch auf vielen anderen Inseln Ozeaniens verbreitet. Es wird angenommen, dass sie mit Besiedlung der Inseln durch das Volk der Lapita weitergegeben wurden, welches in Tattoos eine Möglichkeit sah, ihre Kultur sowohl zu verbreiten als auch zu erhalten (Bellwood, 1989; Rubin, 1988a).

Eine andere, sehr bekannte Tätowierkunst ist das japanische Irezumi, dessen erste schriftlichen Nachweise sich in Aufzeichnungen chinesischer Dynastien finden. Anfänglich wurden Tattoos in neutralem Kontext beschrieben, bald jedoch ein Konzept des tätowierten Barbaren entwickelt, das sich so weit ausdehnte, dass Tattoos sogar als Strafe eingesetzt wurden. Tätowierungen kennzeichneten Straftäter und Aussätzige unwiderruflich und bekamen so erstmals den Beigeschmack sozialer Stigmatisierung (Gilbert, 2001; McCallum, 1988). Der Übergang zum heutigen Irezumi ist kaum dokumentiert, aber im siebzehnten Jahrhundert begann eine Renaissance mit der Ära der Edo-Tätowierungen. Auch diese unterlagen anfänglich noch diversen offiziellen Verboten und wurden meist von Randgruppen der Gesellschaft getragen, welche das Tattoo als Möglichkeit des Protests und zur Kennzeichnung der eigenen Identität nutzten. Dabei entwickelte sich das Irezumi von vereinzelten und einfachen Schriftzeichen und Mustern hin zu komplexen Bildern, die den ganzen Körper bedecken. Solche Ganzkörpertätowierungen zeichnen heute die „traditionelle“ japanische Tätowierkunst aus, wobei sie in ihrer Heimat den negativen Beigeschmack nie verloren haben. Laut McCallum (1988) besitzen sie heute einen gewissen Grad an Ambivalenz: „I suspect there is a high degree of ambivalence about the tattoo; it would seem to be a forbidden fruit with strong erotic overtones blending into ... sadomasochistic fantasies“.

Von Asien gelangte die Tätowierkunst auf den amerikanischen Kontinent (Grieder, 1982). In der frühen Geschichte waren Tätowierungen in ganz Amerika weit verbreitet und dienten als Signal ethnischer Identität und sozialen Status. Bei den Inuit waren Frauen meist mit Linien am Kinn tätowiert, was sowohl ihre Stammeszugehörigkeit, als auch ihren Familienstand kennzeichnete. Männer trugen Tattoos unter anderem als Auszeichnungen besonderer Heldentaten in kriegerischen Auseinandersetzungen mit anderen Stämmen (Gritton, 1988). 


\section{Piercings}

Unter der Praxis des Piercens versteht man das Anbringen von Schmuck an verschiedenen Stellen des Körpers, wobei der Schmuck durch die Haut und das darunter liegende Gewebe gestochen wird. In Nordamerika findet man die ältesten Überlieferungen von Labrets (Lippenpiercings) und Nasenpiercings bei Eskimos der Aleuten. Das Piercen erfolgte meist im Rahmen von Initiationszeremonien, wobei der Schmuck stark regional sowie mit Status und Wohlstand des Trägers variierte. Eine wesentliche Funktion geht mit der Lebensweise der Eskimos einher, bei denen Piercings dazu dienen, den individuellen Platz in der Hierarchie des Lebens als Jäger anzuzeigen (Gritton, 1988). Bei den Azteken Mexikos ist die Existenz von Ohren- und Nasenpiercings überliefert (Rubin, 1988a). Bei Frauen der Tlingits symbolisierte das traditionelle Labret soziale Reife (Jonaitis, 1988). Viele Stämme Südamerikas besitzen heute noch eine Fülle von Körperpiercings, deren Funktionen ebenso vielfältig wie ihre Formen sind. Überwiegend werden sie in Initiationsriten verwendet (Wilbert, 1994). In der Kultur der Maya waren Piercings den Frauen vorbehalten, welche damit die Ästhetik ihres Körpers steigerten; sie nutzten aber auch Tätowierungen und Skarifizierungen, um ihre Körper zu verschönern (Camphausen, 1997).

\section{Skarifizierungen}

Skarifizierungen entstehen dadurch, dass die Haut eingeritzt und sowohl mechanisch als auch chemisch manipuliert wird, um die Narbenbildung zu fördern. Auf dem afrikanischen Kontinent herrscht, nicht zuletzt aufgrund der dunkleren Hautpigmentierung der Bevölkerung, Skarifizierung als Körperkult vor. Auffallend ist hier der Unterschied zwischen den Geschlechtern; generell sind Männer seltener und weniger ausgeprägt vernarbt (Rubin, 1988a). Männer der Nuba schmücken sich beispielsweise nur durch diverse Bemalungen, die zwar sehr markant und individuell sind, aber aktive Narbensetzungen kommen nicht vor. Bei Frauen sind Skarifizierungen die Regel und kennzeichnen physische Veränderungen des weiblichen Körpers. Sie werden in drei Phasen vorgenommen: wenn sich bei Mädchen erste Ansätze von Brüsten zeigen, zu ihrer ersten Menstruation und nach Abstillen des ersten Kindes. Letzteres symbolisiert die erneute sexuelle Verfügbarkeit nach einer langen Phase der Abstinenz (Faris, 1988). Der deutliche Hinweis auf den potentiellen Fortpflanzungszustand 
der Frau demonstriert die Koppelung eines physiologischen Zustandes an den Körperschmuck.

Bei den Tabwa besitzen nur Frauen künstliche Narben. Die Muster haben sowohl ästhetische als auch symbolische Bedeutung. Es gibt zwar stammesspezifische Muster, aber Narben werden im Allgemeinen als schön betrachtet (Roberts, 1988). Bei den Ga'anda sind die Skarifizierungen der Frauen besonders aufwendig und extensiv; sie ziehen sich in sechs Phasen über mehrere Jahre und vermitteln neben dem Reifestatus auch soziokulturelle Werte. Des weiteren stellen sie ein Schönheitsideal dar. Es werden zwar immer dieselben Muster verwendet, aber je aufwendiger die Narben sind, desto höher ist der Brautwert (Berns, 1988). Auch hier beinhaltet Köperschmuck also ein nach außen hin sichtbares Signal, welches die Umgebung über einen biologischen Zustand des Individuums informiert.

\section{Biologische Grundlagen von Körperverzierungen}

Alle drei Arten des Körperschmucks sind invasiv und hinterlassen offene Wunden. Sie können also potentiell Kosten für den Träger verursachen und ohne entsprechende medizinische Versorgung verheerende Konsequenzen nach sich ziehen. Selbst heute gibt es in Deutschland bei jedem dritten Piercing Komplikationen, welche von Entzündungen bis hin zu bleibenden Keloiden oder sogar zur Übertragung einer Infektionskrankheit wie Hepatitis oder HIV reichen (Greif, Hewitt \& Armstrong, 1999; Krause, Bremerich \& Sztraka, 2000; Millner \& Eichold, 2001; Stirn, 2003a). Auch bei Tätowierungen und Skarifizierungen besteht ein hohes Infektionsrisiko, da die Wunden sich meist über große Hautflächen erstrecken. Tätowierfarben sind teilweise kanzerogen und auch hier besteht das Risiko, gefährliche Infektionskrankheiten zu übertragen (Millner \& Eichold, 2001; Papameletiou et al, 2003). Von daher stellt sich für Evolutionsbiologen die Frage, welche Vorteile eine solch invasive Form des Schmucks für die Träger haben.

Im Tierreich sind aufwendige Färbungen und Ornamente als Signale der Parasitenresistenz bekannt (Hamiton \& Zuk, 1982), und auch der Zusammenhang zwischen Ornamentierung und gesteigerter Immunantwort ist vielfach beschrieben (Saino et al, 2003; Saino, Bolzern \& Møller, 1997). Studien zeigten, dass Färbungen durch Carotinoide bei Vögeln Merkmale sind, die der sexuellen Selektion unterliegen (Saino, Bolzern \& Møller, 
1997). Ludvico und Kurland (1995) untersuchten menschliche Skarifizierungen, zu welchen sie auch Tätowierungen und Piercings zählten, zum ersten Mal im Kontext der sexuellen Selektion. Mit Hilfe des ,Standard Cross Cultural Sample' (Murdock \& White, 1969) überprüften sie vier Alternativhypothesen. Danach waren Skarifizierungen entweder als Initiationsritual anzusehen, als Abhärtungsprozedur, als nicht-adaptives Merkmal sexueller Selektion, also ein reines Attraktivitätskriterium, oder als adaptives ,Handicap-Signal’ der sexuellen Selektion (Zahavi, 1975), welches Pathogenresistenz widerspiegelt. Ein HandicapSignal ist ein Merkmal, das durch seine hohen Kosten für den Träger dessen Qualität zur Schau stellt (Zahavi, 1975; 1977). Nur ein Individuum von guter körperlicher Konstitution kann sich ein solches Merkmal leisten und die damit verbundenen Kosten tragen. Ludvico und Kurland (1995) meinen jedoch, dass völkerübergreifend Skarifizierungen nur als nichtadaptive Merkmale sexueller Selektion wirken, nicht als Handicap-Signal.

Singh und Bronstad (1997) untersuchten ebenfalls den Zusammenhang zwischen dem Auftreten von Skarifizierungen und Tätowierungen einerseits, und dem Vorkommen von Pathogenen andererseits. Sie schlossen sowohl ökologische Faktoren, als auch menschliche Partnerwahlkriterien in ihre Argumentation mit ein und stellten für den Vergleich verschiedener Kulturkreise folgende Vorhersagen auf: je höher der Belastungsgrad an Pathogenen in der Umwelt, desto höher sollte der Anteil an permanenten invasiven Körpermarkierungen sein. Diese sollten zusätzlich vor allem in Körperregionen zu finden sein, die als Kriterium für Attraktivität und Partnerwahl eingesetzt werden. Demnach sollten sich Skarifizierungen bei Frauen hauptsächlich an Brüsten und Bauch befinden, beides Signale für Fruchtbarkeit und Jugend. Bei Männern hingegen sollten sie auf Gesicht, Armen und Schultern zu finden sein, also Regionen die männliche Reife und Stärke betonen. Die Autoren konnten ihre Vorhersagen bestätigen; allerdings nur bei Frauen. Je höher die Pathogenbelastung im Lebensraum, desto eher wurden Skarifizierungen auf weiblichen Bäuchen gefunden. Singh und Bronstad (1997) schlossen daraus, dass diese Ornamente daher auch als Qualitätssignal in der Partnerwahl dienen. Der einzige Zusammenhang bei Männern bestand zwischen dem Vorkommen von Skarifizierungen und der sozialen Schicht: Männer aus hohen Schichten waren häufiger ornamentiert. Entgegen den Vorhersagen fanden sie auch, dass Frauen häufiger im Gesicht Skarifizierungen trugen als Männer, was allerdings 
weder mit der Pathogenbelastung, noch mit anderen Faktoren in Zusammenhang gebracht werden konnte.

\section{Der moderne westliche Körperkult}

Die Geschichte der modernen Tätowierung beginnt mit Reiseberichten von James Cook aus Polynesien im 18. Jahrhundert. Obwohl Tätowierungen auch schon früher in der westlichen Welt bekannt waren, z.B. bei Pilgern, traten sie erst mit den Entdeckungsreisen von James Cook und ersten Berichten von Sir Joseph Banks wieder ins Bewusstsein der Europäer zurück (DeMello, 2000; Gilbert, 2001). Cooks Besatzung kam nicht nur mit eigenen Tattoos wieder, sie brachten auch tätowierte Polynesier von ihren Reisen mit. So prägte sich der Begriff der „tätowierten Wilden“, der durch gezielte öffentliche Zurschaustellung der „primitiven“ Tätowierten noch verstärkt wurde (DeMello, 2000). Im späten neunzehnten Jahrhundert gingen auch tätowierte Europäer dazu über, sich selbst zur Schau zu stellen, um damit ihren Lebensunterhalt zu verdienen (Sanders, 1989).

In der Folgezeit gab es neben den negativ stigmatisierten exotischen ,tätowierten Wilden" vor allem Seeleute, die sich auf ihren Reisen von Einheimischen tätowieren ließen. Nach und nach unterlagen Tätowierungen daher einem Wandel und entwickelten sich zum Ausdruck einer speziellen Lebensweise. Vornehmlich Seeleute, Handwerker und Soldaten besaßen Tattoos, deren wesentliche Funktionen die Kennzeichnung der eigenen Identität sowie der politischen und sozialen Zugehörigkeit war. Sie trugen aber auch religiöse Bedeutung oder wurden als Liebesbeweise genutzt. Tätowierungen wurden noch lange mit einem gewissen Freigeist und Abenteuerlust in Verbindung gebracht und blieben in der westlichen Welt bis ins zwanzigste Jahrhundert der Arbeiterklasse vorbehalten (DeMello, 2000; Sanders, 1989).

Zwischen den beiden Weltkriegen erfreute sich die Tätowierkunst vor allem in den Vereinigten Staaten von Amerika eines hohen Grades an Beliebtheit, im Wesentlichen getrieben durch den damit verbundenen Patriotismus. Diese Zeit ist als „,goldenes Zeitalter“ des Tätowierens bekannt. Hier wurden die klassischen amerikanischen Motive geprägt, die meist militärischen oder patriotischen Ursprungs waren, wie z.B. Seeadler oder Anker. Weit verbreitet waren auch bildhafte Gelöbnisse, mit Liebesschwüren und Herzen. Tattoos hatten 
zu jener Zeit einen universellen Charakter und waren für jedermann verständlich, blieben aber weiterhin nur in den unteren Gesellschaftsschichten verbreitet (DeMello, 2000). Nach dem zweiten Weltkrieg fiel die Tätowierkunst allerdings in Missgunst und wurde als barbarisch, unhygienisch und unhaltbar dargestellt. Immer mehr Autoritäten beschäftigten sich eingehend mit der Praxis des Tätowierens, erließen strengere Gesundheitsauflagen und Altersbeschränkungen, was viele Tätowierstudios zur Schließung zwang. Gleichzeitig aber florierten Tätowierungen in Subkulturen und unkonventionellen Gruppierungen (Sanders, 1989). Dies festigte die noch heute tief sitzende negative Stigmatisierung, zu der auch die Brandmarkung von Juden in deutschen Konzentrationslagern, sowie von Straftätern in Frankreich einen Teil beitrugen (Turner, 1999).

In den sechziger Jahren des vergangenen Jahrhunderts war das Tätowieren am Tiefpunkt seines Ansehens angelangt. In der Arbeiterklasse wurde es zwar immer noch im traditionellen Stile praktiziert, gleichzeitig entwickelten sich aber auf den Straßen neue, konfrontationsgeladene Formen. Die wohl bekannteste davon ist das typische ,Biker Tattoo', das sich radikal von dem traditionellen Stil abhebt: es sind rein schwarze, feinlinige Motive, die in der Regel mit nur einer einzelnen Nadel gestochen sind. Sie ähneln in ihrer Art und Weise sehr den Gefängnis-Tattoos, vermutlich, weil viele Biker zu dieser Zeit Gesetzeslose waren und ihr erstes Tattoo im Gefängnis bekamen (DeMello, 1993). Auch die Motive unterschieden sich stark vom traditionellen Stil. Klassische Biker-Motive umfassen Motorräder, Marihuanablätter, Club Logos, Totenköpfe und Schriftzüge. Sie sind meist an Stellen des Körpers positioniert, die für die Öffentlichkeit weitestgehend sichtbar sind und somit sehr provokant angelegt. Auch Frauen, die in der bisherigen Geschichte der westlichen Tätowierung außen vor gelassen wurden, trugen Tattoos. Diese sind von der Biker Kultur nicht mehr wegzudenken und sind nicht nur Gruppenzugehörigkeitssignale und Eintrittskarten in eben diese, sondern auch eine Form von Protest, ein Ausdruck von Trotz und die offensichtliche Distanzierung von den konventionellen Werten der weißen, heterosexuellen Mittelschicht (DeMello, 2000).

Die im Vergleich zu früheren Zeiten zunehmende Variabilität der Zielgruppe führte zur Entwicklung neuer Formen von Tattoos und auch dazu, dass die Tätowierkunst nicht, wie einige Autoren prognostiziert hatten, ausstarb (Schönefeld, 1960). So behielt das Tätowieren 
lange Zeit sein negatives Image - zwar waren es nicht mehr die „tätowierten Wilden“ aus Polynesien, dafür die westlichen Wilden, Mitglieder von Subkulturen und Kriminelle. In Europa wurden Tattoos ebenso wie in Amerika mit Gewalt, Verbrechen und sonstigen Abnormalitäten in Zusammenhang gebracht (Friederich, 1993). Die Medien trugen als vorherrschender Meinungsträger das ihre zur öffentlichen Sichtweise von Tattoos und Piercings bei (Pitts, 1999).

Ein weiteres Aufbegehren kennzeichnet die Punkbewegung der siebziger und achtziger Jahre sowie die Schwulenbewegung, die auch Piercings wieder aus der geglaubten Versenkung hervorholten (Hebdige, 1979; Siebers, 2000). Körpermodifikationen waren zwar noch auf Randgruppen beschränkt, läuteten jedoch allmählich den Aufschwung einer Zeit ein, die heute als „Renaissance“ bezeichnet wird (Pitts, 2003; Rubin, 1988b). In den späten achtziger Jahren weiteten sich Praktiken der Körpermodifikationen in der westlichen Welt so weit aus, dass sie als kulturelle Bewegung bezeichnet werden können. Viele subkulturelle Gruppen begannen, sich selbst als „gemarkte“ Personen zu betrachten und entdeckten ihre Gemeinsamkeiten. Diese lagen vor allem darin, dass sie den menschlichen Körper als eine explorative Stätte sahen, auf welchem sie sich selbst ausdrücken und verwirklichen konnten. Aber auch emotionale Aspekte, die Erfahrung von Schmerz und sexueller Lust an exotischen Ritualen waren vielen Gruppen gemein (Kleese, 1999; Pitts, 2003).

In den neunziger Jahren des letzten Jahrhunderts setzte eine neue Modewelle ein, die bis heute anhält. Diese umfasste allerdings nur Tattoos und Piercings, Skarifizierungen erreichten keinen hohen Grad an Popularität. Die Medien griffen diesen Trend auf, der zuvor von der alternativen Musikszene verbreitet worden war. Immer mehr gepiercte und tätowierte Menschen erschienen im öffentlichen Leben. Heute findet man den Körperschmuck in nahezu allen sozialen Schichten und Altersklassen, wenn auch vorherrschend bei der Jugend. Das ging mit einem Imagewandel einher: früher verschrien und gefürchtet, sind das Tätowieren und das Piercen heute allgemein anerkannte Praktiken (Ferguson, 1999; Pitts, 2003; Sweetman, 1999). 


\section{Funktionen des modernen Körperschmucks}

Bis weit in das zwanzigste Jahrhundert hatten die Praktiken der Körpermodifikationen einen speziellen sozialen Kontext (Turner, 1999), der heute allerdings nicht mehr eindeutig festgemacht werden kann. Man findet den Körperschmuck in allen Gesellschaftsschichten und Altersgruppen und er wird als ästhetisch und von einem Teil seiner Träger als dekoratives Modeaccessoire empfunden. Viele wollen sich auch von der Masse abheben (Sweetman, 1999). Statt einer unitären gängigen Interpretation und soziologischen Bedeutung gibt es eine Fülle von Motivationen, warum sich Individuen tätowieren und/oder piercen lassen.

Atkinson und Young (2001) haben in diesem Zusammenhang sechs Kategorien von Funktionen beschrieben. Demnach können Körpermodifikationen ein Ausdruck von (vor allem subkultureller) Gruppenzugehörigkeit und Protest sein; sie werden zur „,persönlichen Sanierung“ genutzt und können die eigene Spiritualität zum Ausdruck bringen. Des Weiteren kennzeichnen sie Individualität und Kreativität, sind ein Zeichen von physischer Stärke und Schmerztoleranz sowie von Schönheit und Kunst. Gruppenzugehörigkeit als erste Kategorie der Bedeutung von Körpermodifikationen findet sich bereits in der früheren Geschichte der Tätowierkunst wieder. Auch die Protestfunktion wurde schon sowohl in den sechziger Jahren, als auch später in der Punk- und Frauenbewegung genutzt (Atkinson, 2002; Featherstone, 1999). Sich aus Gründen der persönlichen Sanierung tätowieren oder piercen zu lassen, ist ein neues Phänomen. Atkinson und Young (2001) beschreiben, dass vor allem radikale Techniken eingesetzt werden, um sich selbst zu läutern, um seinen Weg zu einem neuen Selbst zu kennzeichnen und auch, dass Rituale der Körpermodifikation bei der Verarbeitung traumatischer Erlebnisse hilfreich sein können. So beschreibt eine ihrer Probandinnen: „I thought a tattoo might help me reclaim my body, bring it back to my control. ... I lost my body when I was raped, I was a stranger in my own skin. ... I cried the whole time I was being tattooed, all of the fear, and hate, and sorrow came to the surface, and every time the needles struck me I relived the pain of the rape. ... [That] day I really started to move on with my life.“ Durch aktive, schmerzhafte Manipulation des Körpers scheint es für manche möglich, die Kontrolle über den eigenen Körper zurück zu erhalten (Featherstone, 1999).

Der Ausdruck von Individualität und Kreativität rührt daher, dass vor allem Tätowierungen vom Träger selbst kreiert sind und dessen eigene Biographie und 
Persönlichkeit sowie die eigenen Körperformen mit einschließen. Von daher sind die Markierungen einzigartig und individuell unverkennbar. Damit hat das Individuum auch die Möglichkeit, sich von der Masse abzuheben, was sehr vielen Tattoo- und Piercingträgern ebenfalls sehr wichtig erscheint (Millner \& Eichold, 2001). Bei invasiven Körpermodifikationen ergibt sich die Bedeutung als ein Zeichen von physischer Stärke und Schmerztoleranz aufgrund der Methodik von selbst. Die Träger solchen Schmucks haben bewiesen, dass sie Schmerzen aushalten können. Andererseits trägt die gemeinsame schmerzhafte Erfahrung auch zu einem Zusammengehörigkeitsgefühl mit Trägern ähnlicher Körpermodifikationen bei (Atkinson \& Young, 2001).

Ein anderer oft genannter Beweggrund vieler Menschen sich tätowieren oder piercen zu lassen beinhaltet ästhetische Aspekte. In einer amerikanischen Umfrage berichteten 43 Prozent der gepiercten und 23 Prozent der tätowierten Teilnehmer, dass sie sich ihren Schmuck aus Gründen der Kunst zugelegt haben. Weitere Gründe besagen, dass die Träger ihn schön und sexy finden (Millner \& Eichold, 2001).

\section{Funktionale Gemeinsamkeiten}

Fasst man Motivationen aus anderen Kulturkreisen zusammen und vergleicht sie mit den oben aufgeführten Beweggründen für den Erwerb von Körperschmuck in heutigen westlichen Gesellschaften, sind einige Gemeinsamkeiten offensichtlich. Das maorische Moko kennzeichnete Status, männliche Stärke, Stammeszugehörigkeit und hatte mythologische, beziehungsweise spirituelle Bedeutung (Gathercole, 1988; Gilbert, 2001). Das japanische Irezumi wurde anfangs als Strafe, dann aber als Protest- und Identitätssignal getragen und wurde auch mit Erotik und Sexualität in Verbindung gebracht (McCallum, 1988). Daneben wurde der Körperschmuck der Amerikaner und Afrikaner meist in rituellem Kontext, zur Initiation oder als Anzeiger bestimmter Reifestadien genutzt und hatte hohen ästhetischen Charakter (Camphausen, 1997; Gritton, 1988; Jonaitis, 1988; Roberts, 1988; Wilbert, 1994). Atkinson und Youngs (2001) Einteilung in sechs Interpretationskategorien lässt sich auch auf diese Funktionen übertragen. Demnach sind Tätowierungen, Piercings und Skarifizierungen eine Form von Körperschmuck, der in seinem jeweiligen Kulturkreis als ästhetisch und schön empfunden wird. Des Weiteren sind sie ein Signal für Einstellung und Zustand des Trägers, 
für Gruppenzugehörigkeit, aber auch Individualität.

Vor dem Hintergrund der potentiellen Risiken und Kosten dieser Körperverzierungen sind die genannten Beweggründe als Erklärungsmodelle für mögliche evolutive Vorteile nicht zufriedenstellend. Das Empfinden der Ästhetik und Schönheit von Körperschmuck scheint auch mit biologischen Erklärungsansätzen für die Existenz ästhetischer Präferenzen vereinbar zu sein. Präferenzen für attraktive Gesichter und Körper erklärt die Verhaltensbiologie mit der Tatsache, dass Unterschiede in Attraktivitätsbeurteilungen durch Unterschiede in der physischen Konstitution des Individuums begründet sind. Präferenzen für attraktive Körpermerkmale gibt es demnach, weil diese Merkmale Hinweis über die biologische Fitness und den Reproduktionserfolg eines Individuums sind (Fink \& Penton-Voak, 2002). Symmetrie und sekundäre Geschlechtsmerkmale zum Beispiel sind „ehrliche Signale“, die von einem Individuum (abgesehen von ästhetisch-chirurgischen Eingriffen) nicht verändert werden können. Die evolutionspsychologische Forschung hat gezeigt, dass diese auch in der Partnerwahl entsprechende Bedeutung haben (Grammer et al, 2003).

Wenn es solche sexuell-selektierten Präferenzen gibt (s. auch Ludvico \& Kurland, 1995; Singh \& Bronstad 1997), ist es naheliegend, dass die Motivation für Körpermodifikationen ebenfalls teilweise in Mechanismen der sexuellen Selektion begründet ist. Eine mögliche Funktion könnte dabei darin bestehen, mit diesen Signalen die Stammesbzw. Gruppenzugehörigkeit an potentielle Partner zu signalisieren. Darüber hinaus gibt es geschlechtsspezifische Motivationen. Weibliche Partnerwahlkriterien, zumindest für Langzeitbeziehungen, zielen im wesentlichen auf Versorgerqualitäten des Partners ab, was sich unter anderem in Präferenzen für sozialen Status und Stärke ausdrückt (Buss, 1989; Buss \& Schmitt, 1993). Diese Funktionen wurden außerhalb westlicher Kulturen hauptsächlich männlichem Körperschmuck zugeschrieben, womit Männer augenscheinlich die Attribute betonen, die in der Partnerwahl von Vorteil sind (Eibl-Eibesfeldt, 1997).

Männliche Partnerwahlkriterien beziehen sich dagegen auf Merkmale der Jugendlichkeit und Fertilität (Buss, 1989). Daher ist es im Kontext der sexuellen Selektion nicht verwunderlich, dass bei Frauen in Naturvölkern der Körperschmuck neben dem ästhetischen Empfinden meist Funktionen der Initiation und des Anzeigens von Fruchtbarkeit hat (Berns, 1988; Faris, 1988). Dies ist ein weiterer, wenn auch vorerst hypothetischer, 
Hinweis auf das Wirken von Mechanismen der sexuellen Selektion im Zusammenhang mit Körperverzierungen. Unsere eigenen vorläufigen Untersuchungen in diese Richtung unterstützen diese Interpretation.

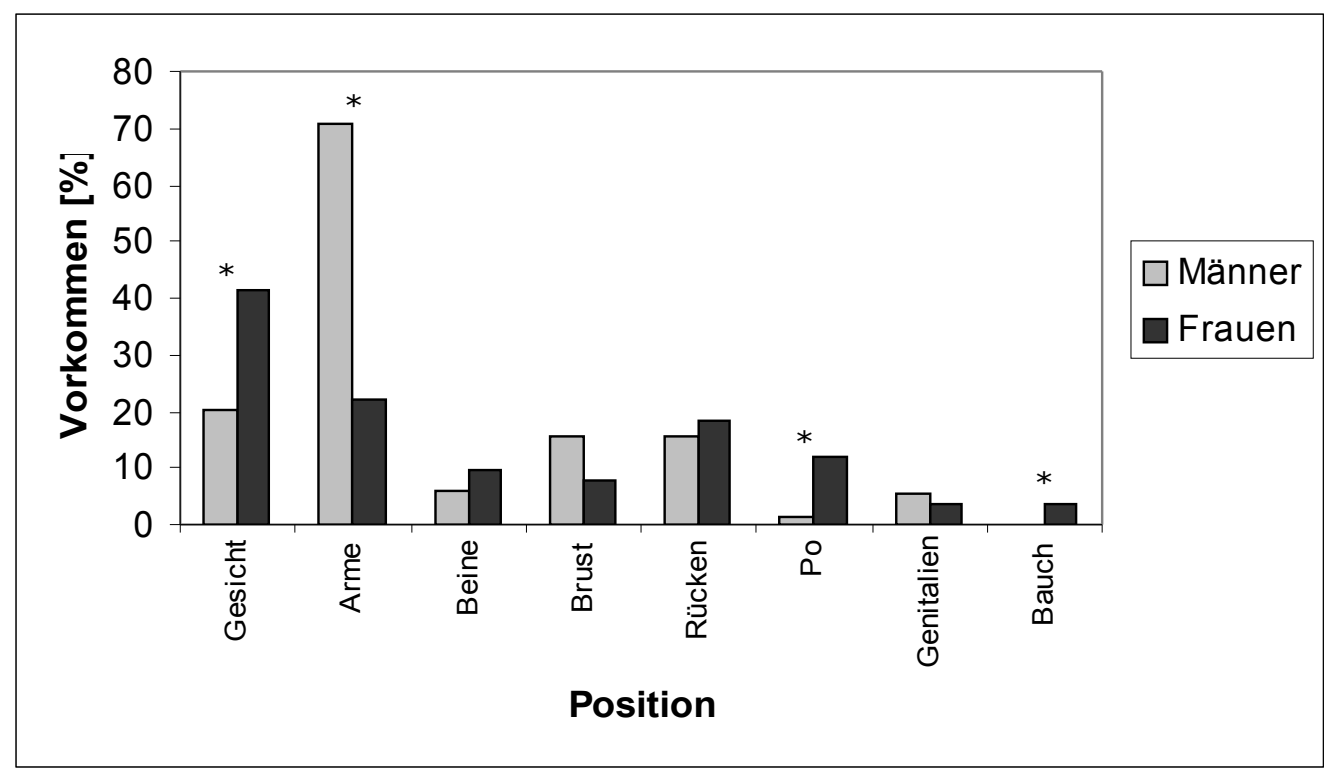

Abb. 1.1 Prozentuales Vorkommen von Körperschmuck (Tattoos und Piercings) bei Mann und Frau an unterschiedlichen Positionen des Körpers. Symbole ${ }^{*}$ ) kennzeichnen einen signifikanten Unterschied (G-Test, p $<0,05)$ im Vorkommen von Körperschmuck zwischen den Geschlechtern an der entsprechenden Position.

In einer repräsentativen Erhebung an über 2500 Deutschen (Institut Marplan, Offenbach, 2003) fanden wir, dass die Position des Körperschmucks sich signifikant zwischen den Geschlechtern unterscheidet (Abb. 1.1). Männer bevorzugen dafür Arme, wohingegen Frauen sich lieber im Gesicht schmücken. Außerdem gibt es einen signifikanten Alterseffekt dergestalt, dass Mitglieder jüngerer Generationen, die noch aktiv am Partnerwahlgeschehen teilnehmen, sich signifikant häufiger schmücken als ältere (Abb. 1.2). 


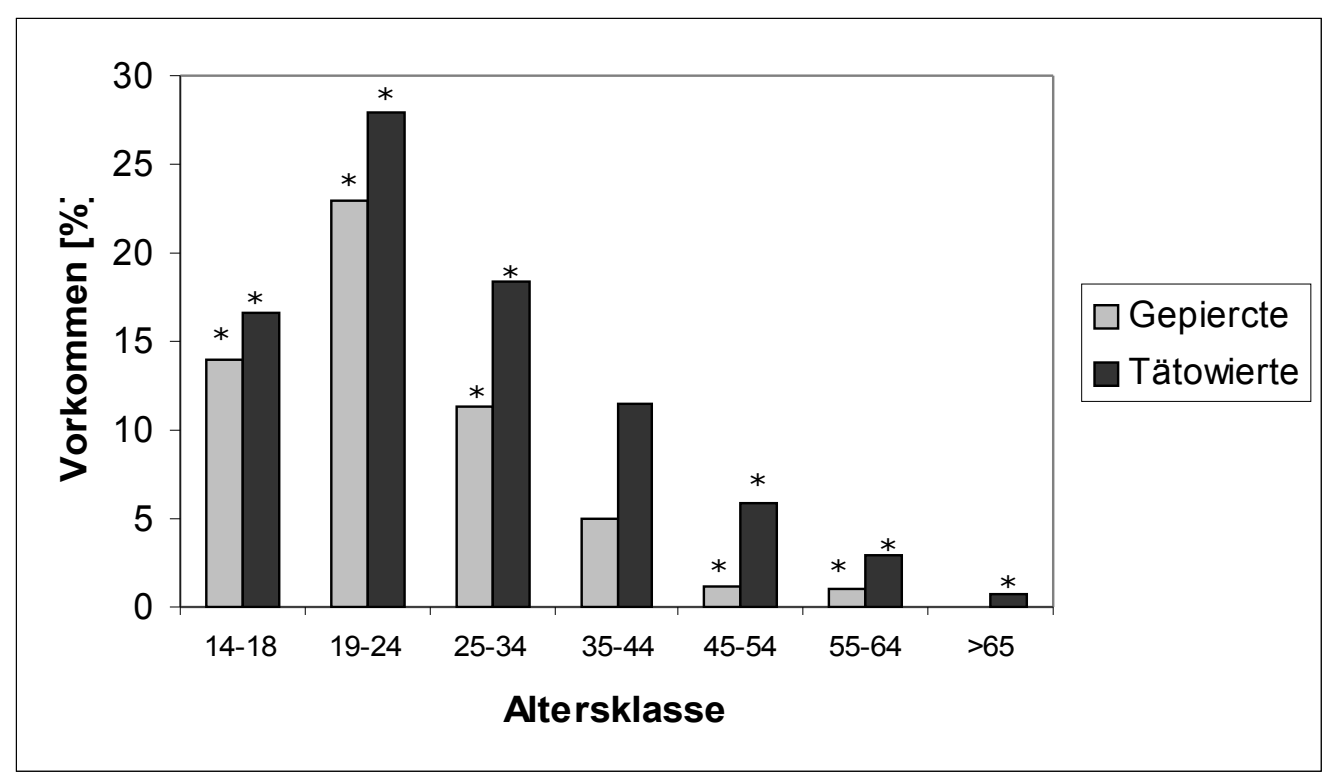

Abb. 1.2 Prozentuales Vorkommen von Tattoos und Piercings in verschiedenen Altersklassen. Symbole (*) kennzeichnen eine signifikante Abweichung (G-Test, $\mathrm{p}<0,05)$ im Vorkommen von Tätowierten und Gepiercten in der jeweiligen Altersklasse von einem Erwartungswert, der sich aus der Altersverteilung der Stichprobe ergibt $(n=2507)$. Hierbei sind die Altersstufen 14-35 signifikant häufiger und die Altersstufen ab 45 Jahren signifikant weniger oft tätowiert und gepierct als erwartet.

All das kann als Hinweis auf eine potentielle Signalfunktion moderner Tattoos und Piercings in der sexuellen Selektion des Menschen gewertet werden und muss in zukünftigen Studien noch genauer überprüft werden. Evolutionäre Prozesse beeinflussen noch heute vielfach das menschliche Verhalten. Ein grundlegendes Verständnis, wann und wo solche biologischen Prinzipien wirken, könnte, zusammen mit kulturellen und ethnischen Aspekten, das generelle Vorkommen, den Fortbestand und auch das Wiederaufleben solcher künstlichen und sehr kostspieligen Körperornamentierungen erklären. 


\section{Chapter 2}

\section{Modifying the body - motivations for getting tattooed and pierced}

Silke Wohlrab*, Jutta Stahl\# \& Peter M. Kappeler*o

* Abteilung Soziobiologie / Anthropologie der Universität Göttingen, Deutschland

○ Abteilung Verhaltensökologie und Soziobiologie, Deutsches Primatenzentrum, Göttingen, Deutschland

${ }^{*}$ Georg-Elias-Müller Institut für Psychologie, Universität Göttingen, Deutschland 


\begin{abstract}
Body modifications have been prevalent for centuries and are practiced for a great variety of reasons. Lately, tattoos and body piercings have become increasingly popular. Thus, a profound understanding of the underlying motivations behind obtaining tattoos and body piercings nowadays is required. A considerable body of research on motivational aspects already exists, mainly using explorative approaches to describe motivations. In this paper we provide a review of the existing relevant literature. Furthermore, we establish ten broad motivational categories, comprising motivations for getting tattooed and body pierced, for reference in future research.
\end{abstract}




\section{Introduction}

Body modification is defined as the (semi-) permanent, deliberate alteration of the human body and embraces procedures such as tattooing and body piercing (Featherstone, 1999). Those practices have a long history and are well known from various cultures in Asia, Africa, America, and Oceania (Rubin, 1988a). There is also evidence for the prevalence of tattoos in Europe, dating back over 5000 years (Caplan, 2000; Dorfer \& Moser, 1998). Although the appearance of tattoos and body piercings varied geographically, they always possessed a very specific meaning for the particular culture. Piercings were often used in initiation rites, assigning their bearer to a certain social or age group (Gritton, 1988; Jonaitis, 1988), whereas tattoos were utilized to signal religious affiliations, strength or social status (Gathercole, 1988; Gilbert, 2001; Schildkrout, 2004). In Europe, the practice of tattooing was predominant among sailors and other working class members from the beginning of the $20^{\text {th }}$ century onwards (Sanders, 1989). Later on, tattoos assigned affiliations to certain groups, such as bikers or inmates (DeMello, 1993, 1995). In the 1980s the punk and the gay movement picked up invasive body modification, mainly as a protest against the conservative middle class norms of society (Pitts, 2003). Until the 1990s, body modifications remained a provocative part of various subcultures (DeMello, 2000; Pitts, 2003).

In the last decade tattoos and piercings have increased tremendously in popularity, rising not only in numbers but also involving a broader range of social classes (DeMello 2000; Sanders, 1989). The main cause of this extension can probably be found in cultural commercialism spread by the media and it comes along with a considerable alteration in signaling function such that body modification does not necessarily assign the bearer to a certain subculture anymore (Pitts, 2003; Turner, 1999; Wohlrab, Stahl, Rammsayer \& Kappeler, in press). Many authors argued that tattoos and body piercings today "are nothing more than fashion accessories" (Craik, 1994; Turner, 1999), whereas others assigned them a deeper psychological meaning. Sweetman (1999) claimed that the permanence, the pain involved as well as the considerable amount of time needed for planning and after-care, especially for tattoos, impose a greater value to them than being simple accessories. Others suggested that body modification might enable traumatized individuals to handle personal experiences (Atkinson \& Young, 2001; Carroll \& Anderson, 2002). Generally, many authors 
ascribed a communicative character to body modifications (e.g., Atkinson, 2004; Stirn, 2004a, b).

What people valued most about their own body modifications was "being different", so tattoos, in particular, can resemble attempts to accentuate one's sense of self-identity (Atkinson \& Young, 2001; Sweetman, 1999) as well as "to attain mastery and control over the body" (Carroll \& Anderson, 2002). Atkinson (2002) explored the meaning of tattoos specifically from women's perspective and found that female tattoos have various functions, including cultural rebellion but also personal reclamation and self-definition. Hence, motivations for the acquisition of tattoos and body piercings seem to be variable.

Motivational investigations are important to provide a basis for understanding why people modify their bodies and simultaneously contribute to the elimination of the outdated negative stigmatization of body modifications. The body of the available literature of more recent dates points towards a change in attitude regarding body modification (Millner \& Eichold, 2001; Schildkrout, 2004; Stirn, 2003a; 2004a, b), and several studies of various disciplines address motivational aspects of tattooing and body piercing. Most studies chose an explorative approach when examining motivations; only some proposed larger motivational clusters (Atkinson \& Young, 2001; Greif, Hewitt \& Armstrong 1999; Stirn, 2004a). With this review, we aim to summarize and structure the large body of available literature on motivations for the acquisition of tattoos and body piercings. Because many motivations seem to be used in various phrasings, we provide a broad description of motivations from the literature and establish general motivational categories for reference in future research.

Tattoos and piercings are generally treated as two different aspects in this review. However, we found that motivations for obtaining both forms of body modification are quite similar - when viewed on a broad scale. Thus, to provide a clear structure in this review, motivational categories for the two practices have identical headlines and are considered the same. Nevertheless, we want to emphasize that detailed motivational aspects, especially concerning the relevance and peculiarity of the specific motivational categories, might differ enormously between tattoos and piercings. 


\section{Motivational categories}

A considerable body of research about why people obtain body modifications already exists in different fields of science (cf. Tables 2.1 and 2.2). Based on those studies, we subsumed the stated reasons to classes of motivations, which describe individuals' impulses to modify their body. In the following, we first provide a general description of ten motivational categories, followed by a more detailed consideration of the categories, differences between tattoos and body piercings and some conclusions arising from this review.

\section{Beauty, Art, and Fashion}

In the current literature, one body of statements comprises motivations such as embellishing the body, achieving a fashion accessory and obtaining a piece of art (e.g., Atkinson \& Young, 2001; Millner \& Eichold, 2001; Stirn, 2004a). Piercings are often used as fashionable accessories, whereas an increasing number of tattooed individuals refer to their tattoos as a piece of art (Siebers, 2000; Stirn, 2001). However, whether piece of art or mere fashion accessory, most authors agree that embellishment is the primary force, so reasons concerning beauty, fashion, and art can be combined in one category (cf. Tables 2.1 and 2.2).

\section{Individuality}

Another line of motivations embraces wishes to create and maintain self-identity, being special and distinctive from others (e.g., Millner \& Eichold, 2001; Stirn, 2004a). The control of the own appearance reflects the creation of identity (McKinley, 1999). Considering the frequency of statements in the literature, the creation of individuality appears to be one of the most important motivations.

\section{Personal narratives}

Motivations such as personal catharsis, expression of personal values and experiences as well as rites of passage are also frequently mentioned in the literature (e.g., Caliendo, Armstrong \& Roberts, 2005; Vale \& Juno, 1989). Atkinson (2002) reported that women, who have been abused, create a new understanding of the injured part of the body and reclaim possession through the deliberate, painful procedure of body modification and the permanent 
marking. The reclamation of the body plays an important role, assigning tattoos and piercings a self-healing effect (Atkinson, 2002; Stirn, 2003b, 2004b).

\section{Physical endurance}

Statements about testing the own threshold for pain endurance, overcoming personal limits, e.g., pain, the pain experience as such and showing off the own toughness comprises a fourth line of reasons. Body modification can display auto-aggressive tendencies (Stirn, 2004b) as well as toughness and the courage to engage in such practices (Atkinson \& Young, 2001). The pain associated with the procedures of body piercing is greatly valued in body modification society (Stirn, 2004b). Additionally, painful stimulation is associated with a release of endorphins in the body, generating positive emotions in addition to an anesthetizing effect (Stirn, 2004a ; Winchel \& Stanley, 1991). This effect might be responsible for an occasionally reported 'lust for pain' (Myers, 1992).

\section{Group affiliations and commitment}

Subcultural membership or the wish to belong to a certain social circle, as well as friendship and love signs have long been mentioned as reasons to obtain body modifications. Body ornaments as permanent sign of commitment are fairly common (e.g., Millner \& Eichold, 2001; Stirn, 2004a) but also the wish to belong to a certain community or to openly show affiliations to subcultural groups have been important for many years (DeMello, 1995; Pitts, 2003; Sanders, 1989).

\section{Resistance}

Frequently stated are also reasons such as protest against parents or society. Invasive body modifications can be provocative, not only due to their invasiveness but also because they have long been associated with subcultural movements and criminal tendencies (DeMello, 2000; Pitts, 2003; Sanders, 1989). A recent study on college students found that especially in adolescents protest against the generation of the parents is a major aspect in acquiring body modification (Delazar, 2005). 


\section{Spirituality and cultural tradition}

Also of relevance are spiritual as well as cultural incitements for attaining body modifications. A movement of body modifiers, the 'neo primitives' practice radical body modifications to emphasize and reveal historical significance of body modification (Vale \& Juno, 1989). Personal affiliations to cultures and their spirituality are also reasons for tattooing and body piercing (Jeffreys, 2000).

\section{Addiction}

Tattoos and piercings possess an addictive character, which might proximately be due to the release of endorphins, associated with the painful penetration of the body, anesthetizing and entailing a positive feeling (Winchel \& Stanley, 1991). Vail (1999) claims an addiction from a more psychological perspective because, for so-called tattoo collectors, it is essential to hold on to their memories, experiences, values or spirituality.

\section{Sexual motivations}

Nipple and genital piercings are quite common and serve as decoration, but also for direct sexual stimulation (Greif et al., 1999; Malloy, 1989; Vale \& Juno, 1989). Expressing sexual affectations or emphasizing their own sexuality through tattooing and body piercing are also common motivations (Armstrong, Caliendo \& Roberts, 2006; Fried, 1983; Langford, 1996; Wright, 1995).

\section{No specific reasons}

Some people also state an impulsive rather than a long decision making process as a reason for acquiring a body modification (Greif et al., 1999). There are also reports of individuals being under the influence of alcohol or drugs while acquiring their piece of body art (Friederich, 1993), thus having (or remembering) no specific personal reason.. 
Table 2.1 References containing motivational statements assigned to categories for tattoos.

\begin{tabular}{ll}
\hline Motivation & References \\
\hline Beauty, art and & Atkinson 2002, 2004; Atkinson \& Young 2001; Blanchard 1994; Claes, Vanderdeycken \& Vertommen \\
fashion & 2005; DeMello 1995; Featherstone 1999; Forbes 2001; Friederich 1993; Hewitt 1997; Houghton, \\
& Durkin, Parry \& Turbett 1995; Huxley \& Grogan 2005; Irwin, 2001; Jeffreys 2000; Kleese 1999; \\
& Makkai \& McAllister 2001; Mifflin 1997; Millner \& Eichold 2001; Myers 1992; Pitts, 1999; Reybold, \\
& 1996; Reyntjens, 2002; Sanders, 1988, 1989; Schildkrout, 2004; Sheppard \& Kwavnick, 1999; Siebers, \\
& 2000; Steward, 1990; Stirn, 2001, 2004a; 2004b; Stirn, Hinz \& Brähler, 2006; Strong, 1998; Sweetman, \\
& 1999; Tiggemann \& Golder, 2006; Turner, 1999; Vail, 1999; Varma \& Lanigan, 1999
\end{tabular}

Individuality Armstrong, 1991, 1995; Armstrong \& McConnell, 1994; Armstrong, Murphy, Sallee \& Watson, 2000; Armstrong, Owen, Roberts \& Koch, 2002; Armstrong, \& Pace Murphy, 1997; Armstrong, Stuppy, Gabriel \& Anderson, 1996; Atkinson, 2002, 2003, 2004; Atkinson \& Young, 2001; Balsamo, 1996; Bazan, Harris \& Lorentzen, 2002; Carroll \& Anderson, 2002; Cimo, 2003; Claes, Vanderdeycken \& Vertommen, 2005; DeMello, 1993, 1995, 2000; Featherstone, 1991, 1999; Fisher, 2002; Forbes, 2001; Frederick \& Bradley, 2000; Friederich, 1993; Gallick, 1996; Greif, Hewitt \& Armstrong, 1999; Grumet, 1983; Hewitt, 1997; Huxley \& Grogan, 2005; Irwin, 2001; Jeffreys, 2000; Kleese, 1999; Koch, Roberts, Armstrong \& Owen, 2005; Laumann \& Derick, 2006; Lin, 2002; Littell, 2003; Makkai \& McAllister, 2001; Marcoux, 2000; Martin, 1997; McKinley, 1999; Mifflin, 1997; Millner \& Eichold, 2001; Nathanson, Paulhus \& Williams, 2006; Oliveira, Matos, Martins \& Araujo, 2006; Phillip, 2001; Pitts, 1998, 1999, 2003; Polhemus \& Proctor, 1978; Reyntjens, 2002; Riley \& Cahill, 2005; Rubio, 2003; Sanders, 1988, 1989, 1991; Schildkrout, 2004; Shilling, 1993; Steward, 1990; Stirn, 2001, 2004a, 2004b; Sweetman, 1999; Tiggemann \& Golder, 2006; Turner, 1999; Vail, 1999; Vale \& Juno, 1989; Wocjik, 1995

Personal narrative Armstrong, Owen, Roberts \& Koch, 2002; Atkinson, 2002, 2003, 2004; Atkinson \& Young, 2001; Benson, 2000; Blanchard, 1994; Carroll \& Anderson, 2002; Cimo, 2003; Coe, Harmon, Verner \& Tonn, 1993; DeMello, 1995, 2000; Featherstone, 1999; Fisher, 2002; Forbes, 2001; Friederich, 1993; Govenar, 1988; Greif \& Hewitt, 1999; Greif, Hewitt \& Armstrong, 1999; Grumet, 1983; Hanes, 2005; Hardy, 1989; Hewitt, 1997; Irwin, 2001; Jeffreys, 2000; Littell, 2003; Martin, 1997; Mercury, 2001; Millner \& Eichold, 2001; Myers, 1992; Pitts, 1998, 1999, 2003; Reyntjens, 2002; Romans, Martin, Morris \& Harrison, 1998; Rubio, 2003; Sanders, 1988, 1989; Sarnecki, 2001; Schildkrout, 2004; Schrader, 2000; Shilling, 1993; Soyland, 1997; Stirn, 2001, 2002, 2003b, 2004a, 2004b; Sweeney, 2006; Sweetman, 1999; Turner, 1999; Vail, 1999; Vale \& Juno, 1989

Physical endurance Atkinson \& Young, 2001; Coe, Harmon, Verner \& Tonn, 1993; Featherstone, 1999; Friederich, 1993; Irwin, 2001; Jeffreys, 2000; Makkai \& McAllister, 2001; Mercury, 2001; Myers, 1992, 1997; Pitts, 1999, 2003; Robinson, 1998; Rosenblatt, 1997; Steward, 1990; Stirn, 2001, 2004a, 2004b; Sweetman, 1999; Vale \& Juno, 1989; Wocjik, 1995

Group affiliations Armstrong, Owen, Roberts \& Koch, 2002; Atkinson, 2004; Atkinson \& Young, 2001; Bazan, Harris \& and commitment Lorentzen, 2002; Blanchard, 1994; Carroll \& Anderson, 2002; Claes, Vanderdeycken \& Vertommen, 2005; Coe, Harmon, Verner \& Tonn, 1993; DeMello, 1995, 2000; Featherstone, 2000; Fisher, 2002; Forbes, 2001; Friederich, 1993; Govenar, 2000; Grumet, 1983; Hebdige, 1979; Houghton, Durkin, Parry \& Turbett, 1995; Kleese, 1999; Laumann \& Derick, 2006; Makkai \& McAllister, 2001; Martin, 1997; Millner \& Eichold, 2001; Myers, 1992; Nathanson, Paulhus \& Williams, 2006; Phillip, 2001; Pitts, 1999, 2003; Polhemus, 1994; Polhemus \& Proctor, 1978; Riley \& Cahill, 2005; Romans, Martin, Morris \& Harrison, 1998; Rosenblatt, 1997; Sanders, 1988, 1989; Schildkrout, 2004; Steward, 1990; Stirn, 2001, 2004a, 2004b; Stirn, Hinz \& Brähler, 2006; Sweetman, 1999; Taylor, 1997; Turner, 1999; Varma \& Lanigan, 1999; Vail, 1999; Vale \& Juno, 1989; Wocjik, 1995

Resistance Atkinson, 2002, 2004; Atkinson \& Young, 2001; Ceniceros, 1998; Delazar, 2005; DeMello, 1995, 2000; Featherstone, 1999, 2000; Fisher, 2002; Friederich, 1993; Govenar, 1988, 2000; Grumet, 1983; Hebdige, 1979; Irwin, 2001; Jeffreys, 2000; Johnson, 1989; Makkai \& McAllister, 2001; Mifflin, 1997; Nathanson, Paulhus \& Williams, 2006; Phillip, 2001; Pitts, 1998, 1999, 2003;Polhemus, 1994; Romans, Martin, Morris \& Harrison, 1998; Rosenblatt, 1997; Sanders, 1989, 1991; Schrader, 2000; Stirn, 2001, 2004b; Taylor, 1997; Turner, 1999; Vale \& Juno, 1989; Varma \& Lanigan, 1999; Wocjik, 1995

Spirituality and Atkinson \& Young, 2001; DeMello, 1995, 2000;Hewitt, 1997; Kleese, 1999; Laumann \& Derick, 2006; cultural tradition Millner \& Eichold, 2001; Myers, 1992, 1997; Pitts, 2003; Rosenblatt, 1997; Stirn, 2001; Sweeney, 2006; Vail, 1999; Vale \& Juno, 1989

Addiction Greif, Hewitt \& Armstrong, 1999; Roberti, Storch \& Bravata, 2004; Vail, 1999

Sexual motivation Atkinson, 2002, 2004; Fried, 1983; Friederich, 1993; Grumet, 1983; Jeffreys, 2000; Kleese, 1999; Koch, Roberts, Armstrong \& Owen, 2005; Levine, 1998; Myers, 1992; Pitts, 2003; Reybold, 1996; Steward, 1990; Stirn, 2004a; Turner, 1999; Vale \& Juno, 1989; Wright, 1995

No specific reason $\quad$ Greif, Hewitt \& Armstrong, 1999; Turner, 1999 
Table 2.2 References containing motivational statements assigned to categories for piercings.

\begin{tabular}{|c|c|}
\hline Motivation & References \\
\hline $\begin{array}{l}\text { Beauty, art and } \\
\text { fashion }\end{array}$ & $\begin{array}{l}\text { Armstrong, Caliendo \& Roberts, 2006; Claes, Vanderdeycken \& Vertommen, 2005; Featherstone, } \\
\text { 1999; Forbes, 2001; Gans, 2000; Greif, Hewitt \& Armstrong, 1999; Hewitt, 1997; Huxley \& Grogan, } \\
\text { 2005; Jeffreys, 2000; Kleese, 1999; López-Jornet, Navarro-Guardiola, Camacho-Alonso, Vicente- } \\
\text { Ortega \& Yánez-Gascon, 2006; Makkai \& McAllister, 2001; Millner \& Eichold, 2001; Myers, 1992; } \\
\text { Pitts, 1998, 1999; Reybold, 1996; Schildkrout, 2004; Sheppard \& Kwavnick, 1999; Skegg, Nada-Raja, } \\
\text { Paul \& Skegg (2007); Stirn, 2003a, 2004a, 2004b; Stirn, Hinz \& Brähler, 2006; Strong, 1998; } \\
\text { Sweetman, 1999; Turner, 1999; Wright, 1995 }\end{array}$ \\
\hline Individuality & $\begin{array}{l}\text { Armstrong, Caliendo \& Roberts, 2006; Armstrong, Ekmark \& Brooks, 1995; Armstrong, Roberts, } \\
\text { Owen \& Koch, 2004; Armstrong, Roberts, Koch, Saunders \& Owen (forthcoming); Balsamo, 1996; } \\
\text { Caliendo, Armstrong \& Roberts, 2005; Carroll \& Anderson, 2002; Claes, Vanderdeycken \& } \\
\text { Vertommen, 2005; Featherstone, 1991, 1999; Forbes, 2001; Frederick \& Bradley, 2000; Gans, 2000; } \\
\text { Greif, Hewitt \& Armstrong, 1999; Hewitt, 1997; Huxley \& Grogan, 2005; Jeffreys, 2000; Kleese, 1999; } \\
\text { Makkai \& McAllister, 2001; Marcoux, 2000; Millner \& Eichold, 2001; Nathanson, Paulhus \& } \\
\text { Williams, 2006; Pitts, 1998, 1999, 2003; Riley \& Cahill, 2005; Roberti, Storch \& Bravata, 2004; } \\
\text { Schildkrout, 2004; Shilling, 1993; Skegg, Nada-Raja, Paul \& Skegg (2007); Stirn, 2004a, 2004b; } \\
\text { Sweetman, 1999; Turner, 1999; Vale \& Juno, 1999; Wocjik, 1995; Wright, 1995 }\end{array}$ \\
\hline Personal narrative & $\begin{array}{l}\text { Armstrong, Caliendo \& Roberts, 2006; Armstrong, Roberts, Owen \& Koch, 2004; Caliendo, Armstrong } \\
\text { \& Roberts, 2005; Carroll \& Anderson, 2002; Featherstone, 1999; Forbes, 2001; Gans, 2000; Greif, } \\
\text { Hewitt \& Armstrong, 1999; Grumet, 1983; Hewitt, 1997; Jeffreys, 2000; Mercury, 2001; Millner \& } \\
\text { Edenholm, 1999; Millner \& Eichold, 2001; Musafar, 1995; Musafar, 1996; Myers, 1992; Pitts, 1998, } \\
\text { 1999, 2003; Roberti, Storch \& Bravata, 2004; Schildkrout, 2004; Shilling, 1993; Skegg, Nada-Raja, } \\
\text { Paul \& Skegg (2007); Soyland, 1997; Stirn, 2002, 2003a, 2003b, 2004a, 2004b; Sweetman, 1999; } \\
\text { Turner, 1999; Vale \& Juno, } 1989\end{array}$ \\
\hline Physical endurance & $\begin{array}{l}\text { Featherstone, 1999; Frederick \& Bradley, 2000; Gans, 2000; Jeffreys, 2000; López-Jornet, Navarro- } \\
\text { Guardiola, Camacho-Alonso, Vicente-Ortega \& Yánez-Gascon, 2006; Makkai \& McAllister, 2001; } \\
\text { Mercury, 2001; Myers, 1992, 1997; Pitts, 1999, 2003; Robinson, 1998; Rosenblatt, 1997; Skegg, Nada- } \\
\text { Raja, Paul \& Skegg (2007); Stirn, 2003a, 2004a, 2004b; Sweetman, 1999; Vale \& Juno, 1989; Wocjik, } \\
1995\end{array}$ \\
\hline $\begin{array}{l}\text { Group affiliations } \\
\text { and commitment }\end{array}$ & $\begin{array}{l}\text { Armstrong, Roberts, Koch, Saunders \& Owen (forthcoming); Carroll \& Anderson, 2002; Claes, } \\
\text { Vanderdeycken \& Vertommen, 2005; Featherstone, 2000; Forbes, 2001; Frederick \& Bradley, 2000; } \\
\text { Gans, 2000; Kleese, 1999; Makkai \& McAllister, 2001; Millner \& Eichold, 2001; Myers, 1992; } \\
\text { Nathanson, Paulhus \& Williams, 2006; Pitts, 1999, 2003;Polhemus, 1994; Riley \& Cahill, 2005; } \\
\text { Rosenblatt, 1997; Schildkrout, 2004; Skegg, Nada-Raja, Paul \& Skegg (2007); Stirn, 2003a, 2004a, } \\
\text { 2004b; Stirn, Hinz \& Brähler, 2006; Sweetman, 1999; Turner, 1999; Vale \& Juno, 1989; Wocjik, 1995 }\end{array}$ \\
\hline Resistance & $\begin{array}{l}\text { Armstrong, Roberts, Owen \& Koch, 2004; Delazar, 2005; Featherstone, 1999, 2000; Gans, 2000; } \\
\text { Jeffreys, 2000; Johnson, 1989; Makkai \& McAllister, 2001; Nathanson, Paulhus \& Williams, 2006; } \\
\text { Pitts, 1998, 1999, 2003; Polhemus, 1994; Rosenblatt, 1997; Stirn, 2003a, 2004b; Turner, 1999; Vale \& } \\
\text { Juno, 1989; Wocjik, } 1995\end{array}$ \\
\hline $\begin{array}{l}\text { Spirituality and } \\
\text { cultural tradition }\end{array}$ & $\begin{array}{l}\text { Gans, 2000; Hewitt, 1997; Jeffreys, 2000; Kleese, 1999; Laumann \& Derick, 2006; López-Jornet, } \\
\text { Navarro-Guardiola, Camacho-Alonso, Vicente-Ortega \& Yánez-Gascon, 2006; Millner \& Eichold, } \\
\text { 2001; Mulacz, 1998; Musafar, 1996; Myers, 1992, 1997; Pitts, 2003; Rosenblatt, 1997; Skegg, Nada- } \\
\text { Raja, Paul \& Skegg (2007); Vale \& Juno, } 1989\end{array}$ \\
\hline Addiction & Gans, 2000; Greif \& Hewitt, 1999; Roberti, Storch \& Bravata, 2004 \\
\hline Sexual motivation & $\begin{array}{l}\text { Armstrong, Caliendo \& Roberts, 2006; Caliendo, Armstrong \& Roberts, 2005; Gans, 2000; Greif, } \\
\text { Hewitt \& Armstrong, 1999; Jeffreys, 2000; Kleese, 1999; Langford, 1996; Levine, 1998; López-Jornet, } \\
\text { Navarro-Guardiola, Camacho-Alonso, Vicente-Ortega \& Yánez-Gascon, 2006; Malloy, 1989; Millner } \\
\text { \& Edenholm, 1999; Myers, 1992; Pitts, 2003; Reybold, 1996; Roberti, Storch \& Bravata, 2004; Stirn, } \\
\text { 2003a, 2004a, 2004b; Vale \& Juno, 1989; Wright, 1995 }\end{array}$ \\
\hline No specific reason & Greif, Hewitt \& Armstrong, 1999; Skegg, Nada-Raja, Paul \& Skegg (2007); Turner, 1999 \\
\hline
\end{tabular}




\section{Relevance of motivations and differences between body modifications}

The above-illustrated ten motivational categories comprise - to our knowledge - all main reasons for obtaining tattoos or body piercings. Tables 2.1 and 2.2 depict references for motivational statements assigned to the established categories. The number of listed studies per category might already point toward a varying relevance of motivations for the acquisition of tattoos and body piercings. A vast majority of studies mentions the expression of individuality and the beautification of the own body as predominant motivations for obtaining body modifications (e.g., Armstrong \& McConnell, 1994; Armstrong \& Pace Murphy, 1997; Frederick \& Bradley, 2000; Greif et al., 1999; Martin, 1997; Millner \& Eichold, 2001; Stirn, 2003a, 2004a). This seems to be prevalent and consistent over social and age classes: tattoos and piercings are acquired to enhance or create beauty and individuality (Armstrong, 1991; 1995; Greif et al., 1999; Schildkrout, 2004; Stirn, 2004a; Vale \& Juno, 1989).

However, relevance and peculiarities of motivations may differ between tattoos and piercings. This can be seen as a consequence of the different characteristics of these practices, especially concerning their permanence. Although laser techniques allow tattoo removal, there still remain visible relics, at least scar tissue (Millner \& Eichold, 2001). Permanence promotes a long lasting decision process concerning tattoos (Sweetman, 1999). In contrast, piercings can be easily removed and do not involve as extensive costs as most tattoos (Armstrong, Roberts, Koch, Saunders \& Owen, forthcoming; Greif et al, 1999; Sweeney, 2006). Thus, the decision making process seems to mirror the quality of the body ornament regarding permanence. Tattoos obviously contain more personal meaning for the bearer, whereas piercings seem to be rather fashionable adornments.

In summary, the major motivations for the acquisition of tattoos and body piercings are very similar and can be expressed by ten categories: beauty, art and fashion; individuality; personal narratives; physical endurance; group affiliations and commitment; resistance; spirituality and cultural tradition; addiction; sexual motivation and no specific reason. Most frequently mentioned in the literature are the expression of individuality and the embellishment of the own body. Other motivations mirror personal attributes and values. Future research should focus on the quantity of motivations to reveal their particular relevance for the acquisition of tattoos and body piercings. 


\section{Chapter 3}

Visual attention to plain and ornamented human bodies: An eye-tracking study

Silke Wohlrab*, Bernhard Fink*, Lennart W. Pyritz*, Moritz Rahlfs* \& Peter M. Kappeler*o

* Abteilung Soziobiologie / Anthropologie der Universität Göttingen, Deutschland

- Abteilung Verhaltensökologie und Soziobiologie, Deutsches Primatenzentrum, Göttingen, Deutschland 


\begin{abstract}
Signaling mate quality through visual adornments is a common phenomenon in animals and humans. However, humans are probably the only species who applies artificial ornaments. Such deliberate alterations of the skin, e.g., tattoos and scarring patterns have been discussed by researchers as potential handicap signals, but there is still very little information about a potential biological signaling value of body modification. In this study eye-tracking was employed to investigate the signaling value of tattoos and other body modification. Measurement of gaze duration of 59 individuals while watching plain, scarred, accessorized, and tattooed bodies of artificial human images indicated that participants looked significantly longer at tattooed than as scarred, accessorized and plain bodies. Generally, male participants paid more attention to tattooed stimuli of both sexes. More detailed analyses showed that particularly female tattooed stimuli were looked at longer. These findings are discussed within an evolutionary framework by suggesting that tattoos might have some signaling value which influences the perception of both male and female conspecifics and may hence also affect mating decisions.
\end{abstract}




\section{Introduction}

In animals, conspicuous ornaments have been demonstrated to serve as social signals in sexual selection, transmitting information about an individual's condition in the context of mate choice and reproductive competition (Grafen, 1990; Zuk, 1991). For example, feather and skin coloration are known to influence sexual attractiveness in animals (Andersson, 1994), and studies on pigmentation in birds indicated that color may signal immunocompetence and health (Blount, Metcalfe, Birkhead \& Surai 2003; McGraw \& Ardia, 2003). The acquisition, as well as the maintenance, of such adornments has to be associated with physical or health costs to function as honest signals (Zahavi, 1975) because only individuals in good condition are able to cope with these physical costs (Zahavi, 1975; Hamilton \& Zuk, 1982; Folstad \& Karter, 1992; Møller \& Petrie, 2001).

Parts of the human body may also act as signals in evaluating an individuals' quality as a mate. However, even though physical attractiveness in humans and its perception have been studied extensively in the past few years (see for reviews Fink \& Penton-Voak, 2002; Grammer, Fink, Møller \& Thornhill, 2003), there is only limited information available on the potential signaling value of the human skin. It has been suggested that skin color has a significant effect on human mate selection because paler skin is a youthful and desired feature (Darwin, 1871; Van den Berghe \& Frost, 1986; Frost, 1988). Fink, Grammer and Thornhill (2001) found that female faces with homogeneous skin are rated higher on attractiveness. More recently, Jones, Little, Feinberg, Penton-Voak, Tiddeman and Perrett (2004) reported that ratings of attractiveness of small skin patches extracted from the left and right cheeks of male facial images significantly correlated with ratings of facial attractiveness. Roberts, Little, Gossling, Perrett, Carter, Jones, Penton-Voak and Petrie (2005) discovered that patches of skin from the cheeks of men that were heterozygous at three loci in the major histocompatibility complex (MHC) were judged healthier than the skin of men who were homozygous, and these ratings correlated with attractiveness judgments of the faces. Together, these studies seem to support the hypotheses that skin condition in humans does provide information about an individual's condition, and men and women perceive variation in skin condition. 
Grammer, Renninger and Fischmann (2004) reported that women show more or less skin when going to night clubs, depending not only on their current relationship status, but also on their intentions to find a partner. Also, there are hints in the literature that different adornments or deliberate alterations of the skin might serve a comparable function. In particular, 'artificial' ornaments on the skin have been suspected of serving as signals of physical quality. Singh and Bronstad (1997) conducted a cross-cultural study, in which they compared the pathogen load with the prevalence of body modifications, such as tattoos and piercings, and found evidence that especially women's scarifications in some body areas might serve as a signal of physical condition, including health. In men, the modifications appeared to be status signals instead, but they nevertheless had a signaling function.

It seems obvious that human body ornamentation serves a signaling function, given that invasive body modification is associated with considerable costs, including time and money, as well as considerable health risks (Long \& Rickman, 1994; Stirn, 2003a). Frequent bacterial infections occur (Stirn, 2003a), together with a risk of infections with blood-borne diseases, such as HIV (Doll, 1988) or hepatitis (Satchithananda, Walsh, \& Schofield, 2001; Mariano, Mele, Tosti, Parlato, Gallo, Ragni, Zotti, Lopalco, Pompa, Graziani, \& Stroffolini, 2004), allergic reactions, and the risks arising from the carcinogenic substances contained in tattooing colors (Tsuruta, Sowa, Higashi, Kobayashi \& Ishii, 2004). Negative social consequences have to be considered as well. Individuals with body modifications such as tattoos were rated less attractive and intelligent (Degelman \& Price, 2002), have reduced chances of employment (Bekhor, Bekhor, \& Gandrabur, 1995), and may experience differential treatment from health care providers (Stuppy, Armstrong, \& Casals-Ariet, 1998).

These negative consequences of body ornaments may be associated with various signaling functions that have been assigned to body modifications in recent history. Tattoos in the 1960s served as group affiliation signals for bikers (Sanders 1989), were distinctive marks of inmates (DeMello, 1993), were used by the punk scene in the 1980s to express their protest against the conservative norms of society (Siebers, 2000; Pitts, 2003), and thereby were associated with the image of the strong, aggressive and masculine man (Atkinson, 2002). Thus, a negative stigmatization was established by mainstream society over the years (Friederich, 1993). Nevertheless, the practice of tattooing became fashionable again in recent 
years, along with an enormous increase in prevalence of body modifications across all social classes (DeMello, 1995, 2000; Wohlrab, Stahl, Rammsayer, \& Kappeler, submitted). With this recent change, the formerly attributed signaling functions were blurred to the extent that they are considered to be mere fashion accessories nowadays (Sweetman, 1999; Millner \& Eichold, 2001).

To contribute to this ongoing debate, the present experimental study used the technique of eye-tracking to assess whether tattoos are perceived by and draw attention from observers. This information is a prerequisite for the evaluation of a potential signaling function because the basis for signaling is the accentuation of a signal from nonsignaling environmental factors (Grammer, 2004). Accentuation should thus draw attention, which can be measured by eye-tracking methods. Generally, eye-tracking measures fast, physiological eye movements and detects where a person is looking. It is assumed that direction of gaze equals focal attention, thereby indicating where the person is focusing his cognitive abilities (Duchowski, 2003). The method has been a useful tool in many domains of cognitive research, such as reading (Ferreira \& Clifton, 1986; Mak, Vonk \& Shriefers, 2002), scene perception (Loftus \& Mackworth, 1978; Henderson, 1999), and face perception (Althoff \& Cohen, 1999), and it has also been successfully used in research on attractiveness. Maner (2003), for example, stated that both sexes attend to attractive female faces but only females attended to attractive male faces.

In the present study, eye gaze was used to investigate focal attention of the participants when looking at plain stimuli, stimuli with tattoos, with scars or with adornments like jewelry. It was hypothesized that images of bodies with tattoos, adornments, and scars would receive greater attention, i.e., longer duration of gaze directed at potential alterations of a body's signaling value than body images without such alterations. Moreover, if tattoos have some signaling value that could influence mate preferences, images of tattooed bodies should attract more intersexual attention than those with fashion accessories or unintentional skin alterations, such as scars. 


\section{Methods}

\section{Participants}

A total of 59 individuals participated in the study, 26 men and 33 women of age between 20 and 60 years $(M$ age $=26.3, S D=.8)$. Seven participants had at least one tattoo themselves; the others were not tattooed. Volunteers were recruited on campus and selected to cover a wide age range to avoid effects of possible generational attitudes towards tattoos. Participants had to have good vision, and neither glasses nor contact lenses were allowed during the experiment, as those might have influenced infrared illumination. Participants were instructed not to move during the course of the experiment. They were told that their eye movements were tracked while they were seeing a number of pictures with 'artificial' human figures (avatars) and intermittent drift corrections, in which they were supposed to fixate the center of the target point. Participants were not given a specific viewing task (Yarbus, 1967). Further, it was not indicated how the stimuli varied, since this might influence the perceptual expectations of participants and thereby alter their focal attention (Duchowski, 2003).

\section{Stimuli}

Stimuli were generated using the software Poser 6 (Curious Labs, Scotts Valley, CA, USA). Three basic female and three basic male human characters were generated. The whole body of each character wearing a bathing suit was shown. For each character, four conditions were created, such that each character was shown once plain, once with a scar, once with an accessory (e.g., necklace or watch), and once with a tattoo (Figure 3.1, below). Scars, accessories, and tattoos were in approximately the same position and were comparable in size and contrast to the skin. They were placed either in the hip or the chest area, which are common tattoo locations (compare Wohlrab, et al., 2007), accessories depending on the type, e.g., neck for necklaces, and scars on suitable locations within the appropriate area. Characters were in front as well as back and side view, depending on the position of the tattoo, scar, or accessory. All stimuli were created in the same lighting conditions to ensure similar contrasts. This resulted in a total of 24 different stimuli (three female and three male stimuli each in four conditions). 


\section{Stimulus presentation}

Stimulus presentation was carried out with 'NBS presentation' (Neurobehavioral Systems, Inc., Albany, CA, USA). An experiment including all 24 stimuli was programmed as a slide show, in which the stimuli were included in a random order. After every fifth stimulus, a drift correction was conducted (see below). Each stimulus was presented for 10 sec. Thus, the total duration of a single presentation of all stimuli was approximately 5 min., including drift corrections. According to Halla (1980), 6 to 8 sec. are sufficient to access relevant information concerning the physical appearance of a person. Therefore the 10 -sec. viewing time per stimulus in this experiment should have been enough for the participants to get an impression of the stimulus and concentrate on parts of specific interest. Each participant took part in one session which lasted about 15 minutes. Each session comprised participants' instruction, positioning at the eye-tracker, and calibration; a single experimental session took about $15 \mathrm{~min}$.

\section{Eye-tracking}

Eye-tracking measures the movement of the eyes and the Gaze Duration fixations on visual stimuli as an indication of cognition in general and focal attention in particular. The iView X High Speed system of SensoMotoric Instruments was used (SensoMotoric Instruments, Berlin, Germany). This system contains a stand-alone tracking column, which houses a camera and infrared illumination integrated into a chinrest. The latter stabilizes the head of the participant, allowing easy calibration and accurate measurements. The tracking column is placed behind a stimulus presentation computer on which the experiment is presented. It is connected via Ethernet to the actual tracking computer used by the operator and in which iView records movement data in real time.

iView $\mathrm{X}$ is a dark eye-tracking system, which used infrared light to contrast the pupil and thereby to map gaze position, after the system was calibrated to relate pupil position to a specific point on the screen ${ }^{1}$. A 19-in flat screen was used for stimulus presentation (Iiyama ProLite E4815) with a resolution of 1280 x 1024, located $50 \mathrm{~cm}$ from the tracking column.

\footnotetext{
${ }^{1}$ For more information on the specific system used and eye-tracking technology applied in this system please visit the website of SensoMotoric Instruments ( $\underline{\text { www.smi.de }})$.
} 
The tracker monitored the left eye's gaze location only and tracked with a sampling rate of $250 \mathrm{~Hz}$, a tracking resolution of smaller than $0.01^{\circ}$, and a gaze position accuracy of down to $0.2^{\circ}$. A 13-point calibration preceded the experiment. The participant was instructed to fixate on the center of a target point, which automatically moved to a different location (13 in total) after a fixation of $400 \mathrm{msec}$. occurred. After every fifth stimulus a drift correction was conducted, at which the participant had to fixate one central target point. Fixation had to be approved by the operator to compensate for small deviations of gaze position after calibration.

\section{Data: Fixation Duration and Gaze Duration}

Raw data were first analyzed using the software BeGaze (SensoMotoric Instruments). The chest and the hip area were defined as areas of interest (AOI's), operationalized as rectangular sections that covered the regions in which the scars, accessories, and tattoos were located. Figure 3.1 depicts those areas of interest exemplarily on a male character in each of the conditions. The areas of interest were designed to cover approximately the same area to allow direct comparison of fixation durations.

Fixations are very slow eye movements that correspond to the participant staring at one particular point. The software detects fixations by applying a maximum-movement threshold for a minimum amount of time $(80 \mathrm{msec}$.). Furthermore, the Gaze Duration for every AOI can be calculated for the 10-sec. stimulus presentation interval. Thus, the Gaze Duration reflects the time span that the participant looked in the area of interest of consideration. However, it does not take into account how often the participant enters or leaves the area of interest with his gaze, which is the number of fixations. 

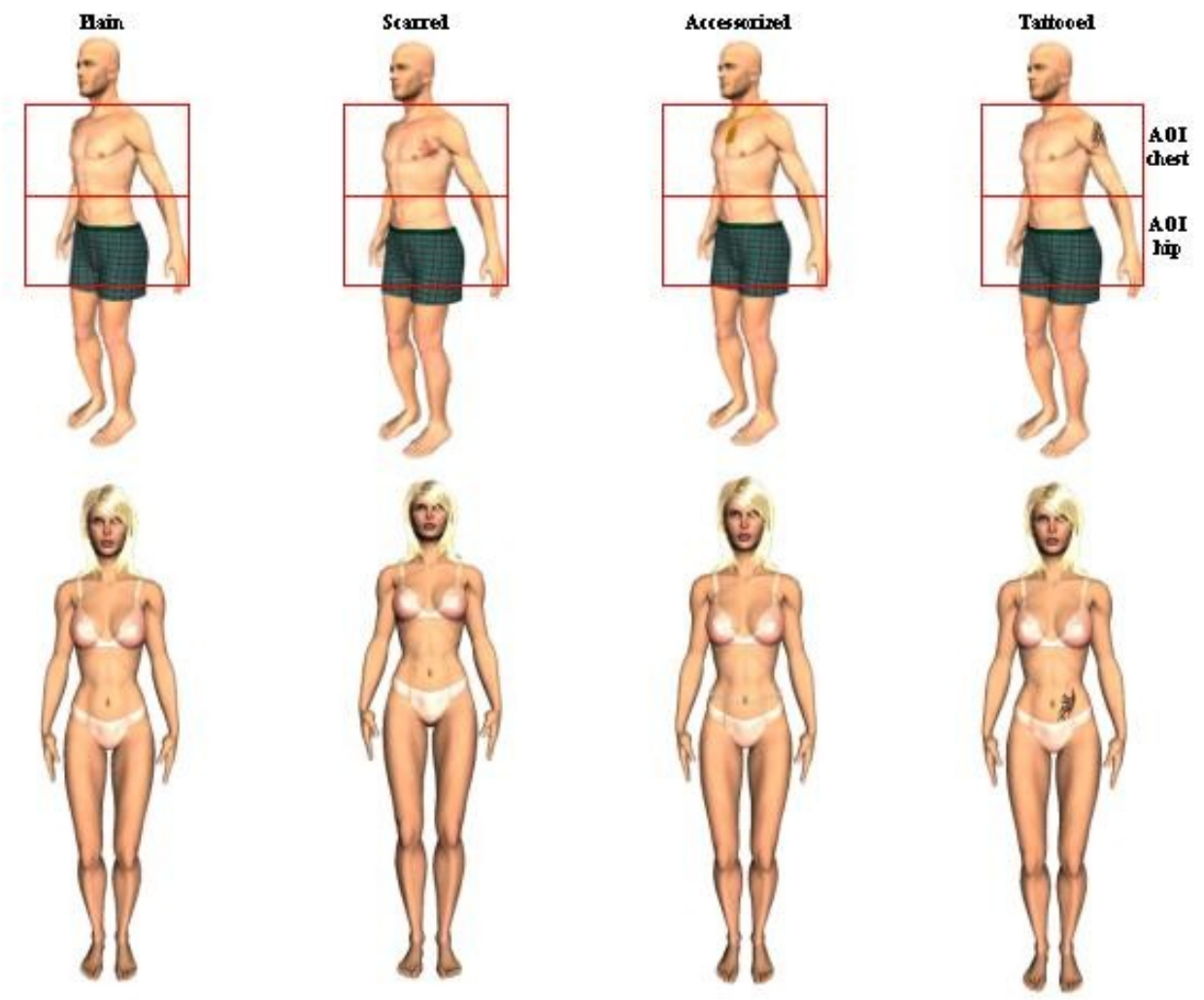

Figure 3.1 One male character in the four varying conditions: plain, scarred, accessorized, and tattooed. The two areas of interest, chest and hip, are indicated. In this example, the area of interest chest is of significance.

\section{Statistical analyses}

To compare the effects of the four conditions, plain, scarred, accessory and tattoo, on Gaze Duration, only the values for the area of interest actually influenced by the condition were taken into account. Thus, only one area of interest per character was compared, since the character's variation was designed to occur in the same location. Independence of data was not given because every participant saw the same character in the four conditions. It was assumed that the sex of stimulus as well as sex of participants might influence Gaze Duration, so those variables were included in the analysis. A repeated-measures analysis of variance was conducted with Gaze Duration as dependent variable, Condition of Stimulus (plain, scar, accessory, tattoo) and Sex of Stimulus (male, female) as a within-subjects factor and the Participant's Sex (male, female) between-subjects factor, yielding a 4x2x2 factorial design. 
All statistical analyses were conducted using SPSS 11 for Macintosh. To estimate effect sizes, partial eta squared $\left(\eta_{\mathrm{p}}{ }^{2}\right.$, ranges from 0 to 1$)$ was reported, which is a common output in SPSS but different from the classical eta squared (see Pierce, Block, \& Agiunis, 2004, for discussion).

\section{Results}

A significant main effect of condition over all participants and stimuli was found $\left(F_{3,55}\right.$ $\left.=11.11 ; \mathrm{p}<0.001 ; \eta_{\mathrm{p}}{ }^{2}=.163\right)$. Sphericity was not violated, thus assumed. With Bonferroni adjusted $p$ post hoc pairwise comparisons showed that the effect was associated with the tattooed stimuli, such that participants looked significantly longer at the body images with tattoos than the plain, scarred and accessorized body images. However, there were no significant differences among the plain, scarred and accessorized stimuli (Table 3.1). Furthermore a significant main effect of Sex of Stimulus was found $\left(F_{1,57}=15.42 ; \mathrm{p}<0.001\right.$; $\eta_{\mathrm{p}}{ }^{2}=.213$ ), such that Gaze Duration was longer for female stimuli, while Sex of Participants did not significantly influence Gaze Duration $\left(F_{1,57}=0.79 ; \mathrm{p}>.05 ; \eta_{\mathrm{p}}{ }^{2}=.014\right)$.

Table 3.1 Pairwise comparisons (Bonferroni adjusted $\mathrm{p}_{.05}$ ) of four different stimulus conditions for six stimuli over all participants $(\mathrm{N}=59)$.

\begin{tabular}{|c|c|c|c|c|}
\hline $\begin{array}{l}\text { Stimulus } \\
\text { Condition(1) }\end{array}$ & $\begin{array}{l}\text { Stimulus } \\
\text { Condition(2) }\end{array}$ & $M_{\text {diff }}$ Gaze Duration (msec.) & $S E$ & $p$ \\
\hline \multirow[t]{3}{*}{ plain } & scar & -157 & 154 & 1.000 \\
\hline & accessory & -226 & 152 & .851 \\
\hline & tattoo & -829 & 123 & .000 \\
\hline \multirow[t]{3}{*}{ scar } & plain & 157 & 154 & 1.000 \\
\hline & accessory & -69 & 180 & 1.000 \\
\hline & tattoo & -672 & 151 & 0.000 \\
\hline \multirow[t]{3}{*}{ accessory } & plain & 226 & 152 & .851 \\
\hline & scar & 69 & 180 & 1.000 \\
\hline & tattoo & -603 & 160 & .002 \\
\hline \multirow[t]{3}{*}{ tattoo } & plain & 829 & 123 & .000 \\
\hline & scar & 672 & 151 & .000 \\
\hline & accessory & 603 & 160 & .002 \\
\hline
\end{tabular}




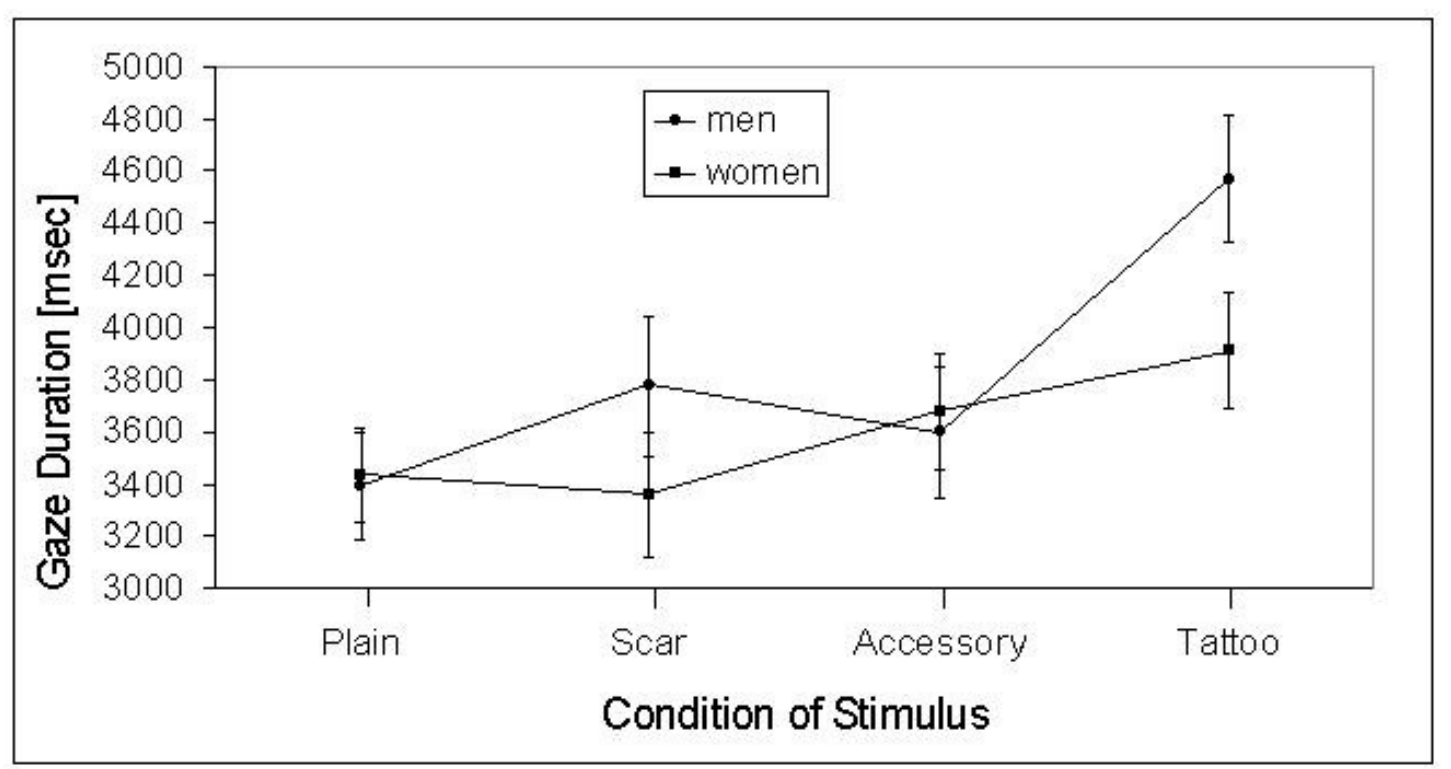

Figure 3.2 Mean \pm SEM Gaze Duration (msec) as a function of Condition of Stimulis for men $(\bullet)$ and women ( $\boldsymbol{\square})$ participants

Significant interactions were found for Condition of Stimulus and Sex of Participant (Figure $3.2 ; F_{3,55}=2.72 ; \mathrm{p}<.05 ; \eta_{\mathrm{p}}{ }^{2}=.046$ ), in which men had longer mean Gaze Durations of scarred and tattooed bodies than women. Also for Condition of Stimulus and Sex of Stimulus a significant interaction appeared, such that female stimuli were viewed longer in all but the scarred condition (Figure $3.3 ; F_{3,55}=9.72 ; \mathrm{p}<.001 ; \eta_{\mathrm{p}}{ }^{2}=.146$ ). Interactions between Sex of Stimulus and Sex of Participant $\left(F_{1,57}=0.23 ; \mathrm{p}>.05 ; \eta_{\mathrm{p}}{ }^{2}=.004\right)$ as well as between the latter two and Condition of Stimulus were not significant $\left(F_{3,55}=1.54 ; \mathrm{p}>.05 ; \eta_{\mathrm{p}}{ }^{2}=\right.$. 026). 


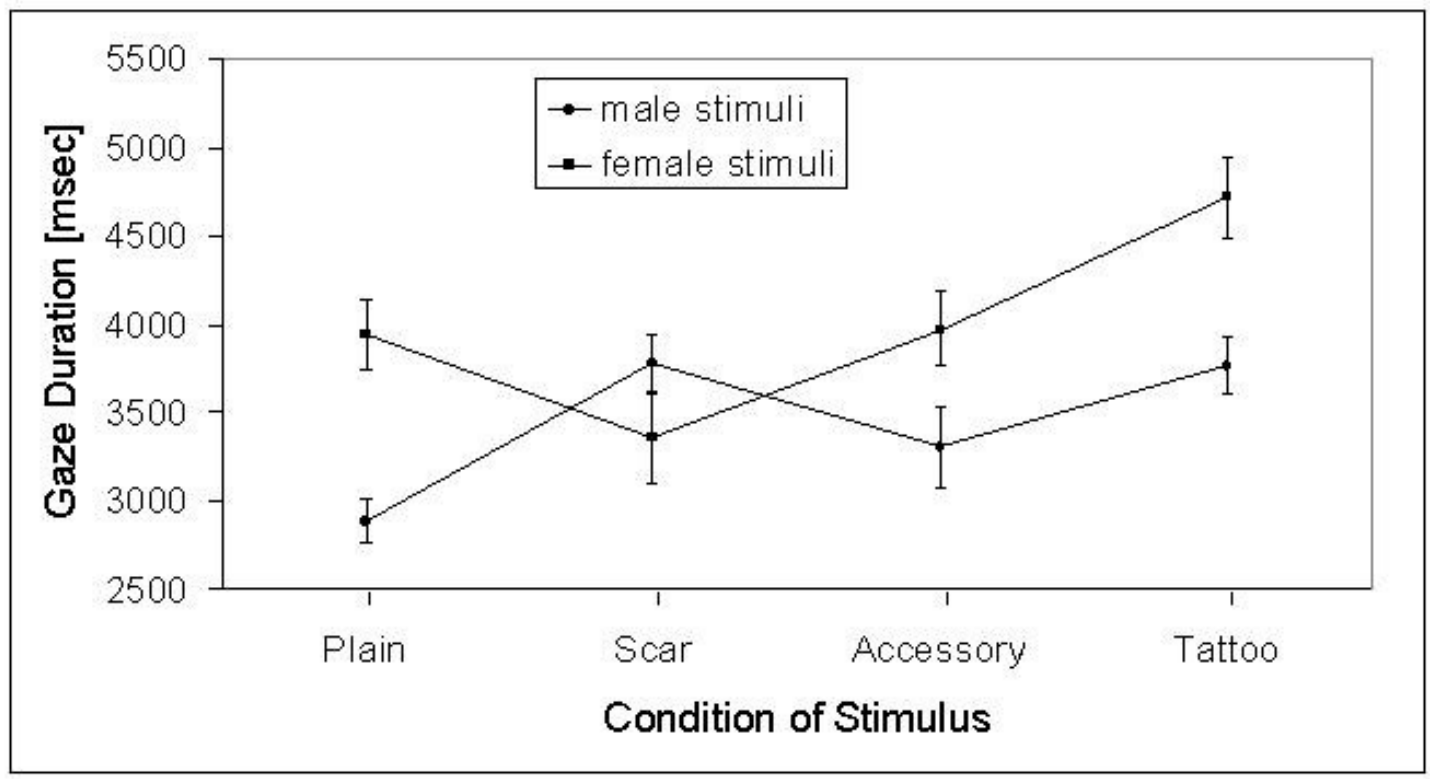

Figure 3.3 Mean \pm SEM Gaze Duration (msec) as a function of Condition of Stimulis for male $(\bullet)$ and female ( $\boldsymbol{\square})$ stimuli

\section{Discussion}

The results basically support the hypothesis that body condition influences attention towards the body area, since viewing time was generally longer for the body-modified stimuli. In particular, participants devoted significantly more attention to figures with tattoos than those with accessories, scars, and plain body images. Plain bodies received the least attention, followed by scarred, accessorized and tattooed with the longest Gaze Duration. Although this might be related to the phenomenon that attention tends to jump to something new (von Helmholtz, 1925) or something which differs from plain surface (Doll, Worther, \& Schmieder, 1993), the constant and systematic variation supports the basic hypothesis, that specifically tattoos draw attention, since tattoos were responsible for the significant main effect. The ranking of conditions suggests that 'natural' alterations might bear less differentiated information and so do not attract as much attention. However, the scarred and accessorized conditions were chosen to be comparable to tattoos, by either being skin alterations or fashionable adornments, which also bear visual information. Nevertheless, mean 
Gaze Duration in those conditions was significantly shorter than for tattooed bodies, indicating the potential signaling function of tattoos, although Gaze Duration only bears information about visual attention but not about the quality of a signal. Given these limitations, the subsequent interpretations of the results should be regarded as speculative and reflect rather preliminary data for a research program. However, from the literature available it seems warranted to comment on these findings in relation to the supposed evolutionary significance of body modifications.

With regard to the signaling characteristics of tattoos, in particular, a significant interaction was found for Condition and Sex of Participants. Further analyses indicated that men looked longer at scarred and tattooed bodies than women. Also, the Sex of the Stimulus influenced Gaze Duration as female stimuli were looked at longer in all conditions except the scarred bodies. In combination, there may be intersexual effects of tattoos concerning attention, as would be expected if they signaled 'quality' as a mate. Tattoos as quality or handicap signal in women have been suggested by Singh and Bronstad (1997), who examined the relationship between pathogen load and the prevalence of body modifications in a crosscultural sample. In this sample similar sex differences emerged with respect to attention. Specifically, male participants specifically looked longer at tattooed bodies of both sexes, suggesting a potential further signaling function in male competition for mates. However, female tattooed stimuli received more attention in general. In sum, a signaling function of tattoos in the context of sexual selection is consistent with the present results, but further interpretations must be viewed with caution because the interaction of all three variables, Sex of Participant, Sex of Stimulus and Condition of Stimulus, was not significant.

Other possible explanations for differing Gaze Durations could be misleading expectations by the respondent who perceived the tattoo (Duchowski, 2003). In other words, when tattoos were more common in men, tattoos in women were unusual and so drew more attention from the respondent. However, tattoos are nowadays equally common in German men and women (Wohlrab, Fink, \& Kappeler, 2005). Moreover, the locations for the tattoos are commonly used for real tattoos in men as well as women (Wohlrab, et al., 2007). Thus, the sex-specific difference in Gaze Duration on tattoos may be explained rather by the fact that especially male observers expect to obtain more information and also more differentiated 
information from tattoos than they expect from other conditions.

Previous studies identified various kinds of information signaled by tattoos. In primitive tribes, for whom deliberate alterations of the skin have a long history, tattoos were used as a status symbol (Gilbert, 2001), for social stigmatization (McCallum, 1988) and denoted clanship (Gritton, 1988). In Western cultures, tattoos also signaled group membership for sailors in the early twentieth century (Sanders 1989; DeMello, 2000) and for bikers and inmates later on (Sanders 1989; DeMello 1993, 2000; Friederich, 1993). They were used as protest signals against the conservative norms of society in subcultural movements (Hebdige, 1979; Siebers, 2000). Nowadays, tattoos are fairly common in all classes of society and may function as fashion accessories (Ferguson, 1999; Sweetman, 1999; Pitts, 2003). However, the present results suggest a possible biological signaling function as quality signals of potential mates and point towards an additional function in competition among mates.

Some drawbacks of the method of eye-tracking should be kept in mind when interpreting the results of this study. Eye-trackers are generally supposed to offer an objective view of visual attention because it is assumed that attention is directly linked to foveal direction of gaze. This holds true most of the time, but not always (Deubel \& Schneider, 1996). Humans are capable of intentionally dissociating attention from foveal vision (Grindley \& Townsend, 1968; Posner, 1980), which cannot be pursued by eye-tracking. Furthermore, the context of a scene (Rayner, 1998) and the complexity of an object might alter fixation times, with more detailed objects which are harder to integrate into a scene demanding longer fixation for identification than simple objects with fewer visual elements (Solso, 1999). Also, features that simply deviate from plain surfaces are more likely to be fixated (Doll, et al., 1993). Familiarity with the object might influence fixation number and time (Greene \& Rayner, 2001). Nevertheless, eye-tracking offers insight into overt visual attention. When viewing a picture visual attention is first through peripheral vision at low resolution. At this stage, interesting features might pop up and draw attention to their location. Thus, eyes are repositioned, directing the fovea toward this region of interest to investigate the feature at a high resolution (Duchowski, 2003). In the present study, stimuli were shown randomly in the experiment but, after initial randomization, there was no change in order of stimuli. Thus, order effects might have influenced the data. Indeed, scanning behavior 
decreased over the course of the study, but this might be associated with increased familiarity with the stimuli (Greene \& Rayner, 2001).

In conclusion, the study indicated that tattoos potentially act as visual signals. They also seem to bear information, which is different from other body alterations, such as scars and fashion accessories. Females' tattoos draw more attention, and male viewers look longer at tattoos in general, which points towards differentiated and sex-specific information concerning male and female tattoos. Further research is needed to examine signaling functions of modern tattoos by directly assessing the received impression of a tattooed body compared to a non-tattooed body. Also, researchers should address attention when comparing artificial ornaments, like tattoos, and natural ornaments connoting mate quality, such as male shoulders or chest muscles and female breasts, hips or waist. 


\section{Chapter 4}

Differences in personality characteristics between body-modified and nonmodified individuals: Associations with individual personality traits and their possible evolutionary implications

Silke Wohlrab*, Jutta Stahl”, Thomas Rammsayer", Peter M. Kappeler*o

* Abteilung Soziobiologie / Anthropologie der Universität Göttingen, Deutschland

- Abteilung Verhaltensökologie und Soziobiologie, Deutsches Primatenzentrum, Göttingen, Deutschland

\# Georg-Elias-Müller Institut für Psychologie, Universität Göttingen, Deutschland 


\begin{abstract}
After a long history of negative stigmatisation, the practices of tattooing and body piercing have become fashionable in the last decade. Today, $10 \%$ of the population in modern western societies have some form of body modification. The aim of this study was to quantify the demographic and personality traits of tattooed and pierced individuals and to compare them with a control group of individuals without body modifications. These comparisons are based on questionnaires completed by 359 individuals that investigate the details of body modification, and which incorporate five personality scales. We describe several sex differences in ornament style and location. We found no relevant differences between modified and non-modified individuals in relation to demographic variables. This indicates that some of the traditional attitudes towards tattoos and piercings appear to be outdated. However, we found striking differences in personality traits which suggest that body-modified individuals are greater sensation seekers and follow a more unrestricted mating strategy than their non-modified contemporaries. We discuss these differences in light of a potential signaling function of tattoos and piercings in the mating context.
\end{abstract}




\section{Introduction}

Body markings, such as tattoos and piercings, have a long history and are widespread among many cultures (Wohlrab, Fink \& Kappeler, 2005). The practice of tattooing in Europe can be traced back over 5000 years to a mummy found in an Italian glacier (Dorfer \& Moser, 1998). In modern history, the rediscovery of tattoos was initiated by travel reports by James Cook and his crew, who not only obtained tattoos from the natives of Polynesia, but also brought natives back to Europe for public displays (Gilbert, 2001). Events like this contributed to the image of the "tattooed savage" and a long history of negative stigmatisation in western culture towards any form of invasive body modification. Today, variation among individuals in the presence/absence and type of body modification can be analysed from at least three perspectives.

First, from a sociological perspective, body modification has undergone major changes in function particularly in the past two decades. Initially, tattoos in post-industrialised western societies were largely restricted to certain groups which were considered to have aggressive and/or criminal tendencies such as sailors, soldiers, bikers and prisoners. Specific tattoos or tattoo styles were used to identify group members and represented a protest against conservative values of the middle class (DeMello, 2000). Thus, non-tattoed people associated body modification practices with criminal, aggressive and deviant behaviour. In the late 1980s however, tattooing and body piercing experienced a boom in popularity (Rubin, 1988b; Siebers, 2000). This fashion wave still exists and today tattoos as well as piercings are found in every social and age class (DeMello, 2000). This development was presumably accompanied by a change in the image of body modification in general from an ill-reputed to a more broadly accepted mainstream practice.

Second, from a biological perspective, body modifications, just as natural ornaments in the animal kingdom, can be analysed with respect to their potential proximate and evolutionary functions. In terms of proximate functions, body modifications serve as visual communication signals. Whereas most tattoos are placed on body parts that can be easily covered, they are quite evident when uncovered. Most piercings are positioned prominently in the facial region and thus easily seen, but they can also be easily removed. Therefore, bearers of tattoos and piercings can and usually do control the presentation of these signals. A 
biological signaling function of these ornaments is exacerbated by their costs in terms of both financial investment and health risks. Every third piercing causes severe infection and tattoos can provoke allergic reactions and bear the risk of the transfer of blood-borne diseases (Goldberg \& Anderson, 2004; Kral, Bluthenthal, Lorvick, Gee, Bacchetti \& Edlin, 2001; Mariano et al., 2004; Stirn, 2003a). Body ornaments may therefore serve an evolutionary function as handicaps in the context of mate choice or competition for mates. The handicap principle expresses that ornaments reflect the bearers biological quality as only high-quality individuals can cope with the costs entailed (Zahavi, 1975). To date however, only indirect evidence based on an inter-cultural study is available to support this hypothesis (Singh \& Bronstad 1997).

Finally, body modifications can also be viewed from the perspective that they convey social information unrelated to a potential handicap function. The existing scientific literature on tattoos and piercings has mainly concentrated on their prevalence and significance in terms of people showing antisocial, aggressive, high-risk or deviant behaviours. For example, Carroll, Riffenbourgh, Roberts and Myhre (2002) found that tattoos and piercings were strongly associated with high-risk behaviour among patients of an adolescent health clinic (see also Roberts \& Ryan, 2002; Roberts, Aulinger \& Ryan, 2004). Other studies examined personality traits in non-delinquent samples and found that tattooed individuals had higher scores in sensation seeking (Roberti, Storch \& Bravata 2004) as well as extraversion and body consciousness (Delazar, 2005). Furthermore, Nathanson, Paulhus and Williams (2006) examined tattoos and body piercings as indicators of cultural deviance markers and suggested that they 'may be indirect markers of personality'. Interestingly, even children have certain negative perceptions of tattoed adults (Durkin \& Houghton, 2000).

To our knowledge, however, no previous study has examined sociological, biological and personality aspects of body modification in one sample of individuals. It is of major interest to reveal potential signaling functions of body ornaments especially if they reflect the basic attitudes (related to basic or more specific personality characteristics) and values of body-modified individuals which lead to influences on patterns of social interactions, including mating strategies. In our study, we compared ornamented and non-ornamented subjects with respect to several variables. First, we documented variation in socio- 
demographic traits. We employed the Big Five Inventory (BFI, Lang, Luedtke \& Asendorpf, 2001) to record the basic personality dimensions of the individuals sampled and to replicate previous findings in a different sample (Delazar, 2005; Nathanson et al., 2006). We also investigated relevant context-specific behaviours which might be associated with a potential signaling function of tattoos and piercings. We applied the Sensation Seeking Scale (SSS-V, Zuckerman, 1979) because body modification itself can be counted as a risky event and an extreme sensation (see Roberti et al., 2004). With respect to the potential biological functions of ornaments, we determined the subjects' Sociosexual Orientation (Simpson, 1998; Simpson \& Gangestad, 1991). We used the Questionnaire on the Perception of One's Own Body (Strauß \& Appelt, 1983) to examine the attitudes of individuals towards their own physical appearance, which we expected to differ in individuals who invasively alter their body (e.g. Atkinson \& Young, 2001). Finally, we were particularly interested in stereotypical gender related traits which could be (partly) independent from the individual's sex (Bem, 1974).

\section{Methods}

\section{Participants}

Volunteer tattooed, pierced, and non-modified individuals $(n=359)$ were recruited in various locations and occasions, including a general hospital $(n=44)$, two pubs $(n=74)$, a public beach $(n=41)$, a tattoo convention $(n=15)$ and a student class $(n=15)$ in and around Goettingen, a university town in central Germany. Individuals were recruited between June 2004 and July 2005. Participants were chosen irrespective of their possession of a visible body modification and they were not specifically informed about the purpose of the survey. Participants filled in questionnaires on site which took between 30 and 45 minutes. Additional body-modified participants $(n=170)$ were recruited via posters which advertised the survey as an investigation on body modification. Data from 43 participants were excluded from analyses due to incomplete questionnaires. All participants confirmed their willingness to participate in this study after they were informed that their responses would be kept confidential and that no individual assignment from the published results was possible. The sample was divided into four groups: only-tattooed, only-pierced, both types of body modification, and non-modified individuals (see Table 4.1). 
Table 4.1 Mean age \pm standard deviation, (number of participants) as a function of sex and body modification.

\begin{tabular}{|c|c|c|c|c|c|}
\hline & \multicolumn{2}{|c|}{ Body modification } & \multirow[b]{2}{*}{ Only pierced } & \multirow[b]{2}{*}{ Tattooed and pierced } & \multirow[b]{2}{*}{ Total } \\
\hline & Non-modified & Only tattooed & & & \\
\hline Males & $30.2 \pm 8.4(71)$ & $30.9 \pm 6.8(35)$ & $26.4 \pm 6.2(24)$ & $29.1 \pm 8.4(37)$ & $29.1 \pm 7.9(167)$ \\
\hline Females & $31.0 \pm 11.8(63)$ & $28.3 \pm 8.2(39)$ & $24.5 \pm 5.6(44)$ & $25.3 \pm 5.7(46)$ & $27.3 \pm 9.0(192)$ \\
\hline Total & $30.6 \pm 10.2(134)$ & $29.6 \pm 7.6(74)$ & $25.2 \pm 5.9(68)$ & $27.0 \pm 7.3(83)$ & $28.5 \pm 8.6(359)$ \\
\hline
\end{tabular}

\section{Instruments}

\section{Demographics}

The questionnaire on demographics contained questions about age, gender, education, job, relationship status, as well as sexual orientation and 'uncommon' sexual interests. The latter points were asked in the form of open questions and answers ranged from fetishism to sadomasochism. Because such a variety of answers was not helpful in addressing the general research question, we generalised such specific sexual interests as 'uncommon'. In order to characterise educational background, six different levels were used: the first comprised participants who were still completing education $(n=15)$, the second was for those without completed education $(n=3)$, the third encompassed individuals having the German 'Hauptschulabschluss' $(n=15)$ (comparable to CSE), the fourth contained individuals with the German 'Realschulabschluss' ( $n=68$ ) (comparable to junior high school graduation), the fifth covered individuals having the German 'Abitur/Fachabitur' ( $n=200)$ (comparable to the English A-levels) and the sixth included participants with a university degree $(n=56)$. In relation to jobs, 132 participants were undergraduate students, 1 was a graduate student, 15 were still completing education and 10 participants were unemployed. One participant did not indicate his/her job or education. The remaining 200 participants worked in various jobs ranging from doctors and engineers to warehouse workers. Additionally, participants were asked to state membership to a subcultural group if this was applicable. Several subcultures were listed for check marking in the questionnaire including bikers, hip hop, heavy metal, rastafarians, skaters, gothics, hippies, punks, ravers, skinheads and the categories 'others' and 
'none'. Sexual orientation was divided into 'heterosexual' or 'other'. The design, location and size of each tattoo and/or piece of jewellery were also documented.

\section{Body Piercings}

Piercings were defined by the method of acquisition such that conventional earrings were excluded from the study. The latter require a procedure whereby the earring is directly pushed through the earlobe using a specific piercing gun. In contrast, non-earlobe piercings are generally made by removing tissue using a hollow needle (canula) before inserting the jewellery. Piercing jewellery was divided into 'standard ring or barbell', 'decorated ring or barbell', 'twister', 'plug', 'flesh tunnel', 'claw' and 'other'. Standard rings and barbells contain plain, mainly standard silver shaped jewellery, whereas decorated rings and barbells comprise jewellery with the standard shape but with coloured pebbles or other decorations. Twisters and claws were specifically classified according to their name. A plug is a solid squit used to stretch piercing holes, while flesh tunnels represent hollow plugs. Additionally, the location for each piercing was recorded.

\section{Tattoos}

Tattoo design categories were established in advance by aggregating designs with similar provenance or style and were listed in the questionnaire. For each category, at least two exemplary pictures were included. The following ten categories were listed: 'tribals', 'symbols', 'fantasy and science fiction', 'animals and nature', 'flowers', old school tattoos', 'skulls, skeletons, daggers and knives', 'lettering tattoos', 'oriental style' and 'others'. Common tribal tattoos comprise bold, black, silhouette style designs. Old school tattoos stand for a very specific style of traditional tattooing with rough lines, bright colors and oldfashioned symbols like clippers, anchors and hearts. Oriental style denotes Asian tattooing which takes into account the whole body and incorporates patterns and figures from eastern mythology. The remaining categories aggregate designs according to their names and are thus self-explanatory.

To obtain information on the location of tattoos, the human body was divided into several main areas which were indicated on a drawing included in the questionnaire. Furthermore, size categories were assessed for each tattoo in relation to the proportion of skin 
they covered. For subsequent analyses, tattoo size was converted into the percentage of total skin surface area covered. Therefore, the percentage of skin from each body location was estimated by the 'Rule of Nines', which is used in medical studies to estimate the severity of burns (Wilson, 1996). Thus, the face has 7\%, the throat and neck $2 \%$, shoulders $4 \%$, the upper back $5 \%$, lower back $4 \%$, the chest $7 \%$, the abdominal area $4 \%$, the genital region $3 \%$, the bottom $5 \%$, upper arms $8 \%$, lower arms $6 \%$, hands 5\%, femorals $11 \%$, lower legs $10 \%$ and feet $7 \%$ of the total skin surface of the human body. These derived categories offer a good and problem-oriented approach to quantify tattoos' size.

\section{Psychometric measures}

The German version (Lang et al., 2001) of the BFI (John, Donahue \& Kentle, 1991) was used to document personality type according to the Five-Factor Model (Costa \& McCrae, 1985; Goldberg, 1990). The inventory consists of 42 personality statements which are specifically keyed on a factor scale of Extraversion, Agreeableness, Conscientiousness, Openness to Experience and Neuroticism. Statements had to be rated on a scale from 1 ('strongly disagree') to 5 ('strongly agree'). Scores were summed separately for each subscale. Individuals with high scores on the Extraversion scale possess such attributes as sociable, talkative, energetic and assertive. Agreeable individuals could be described as friendly, cooperative and warm. The Conscientiousness scale measures whether the individual is more or less cautious, responsible and organised. Thus, individuals with a high level of Conscientiousness could also be characterised as less impulsive. Neuroticism, also called emotional instability, refers to an individuals' tendency to be high-strung, tense, and worrysome. Finally, individuals with high scores on the Openness scale were described as artistic, imaginative, witty and original (John et al., 1991; John \& Srivastava, 1999).

We used the German adaptation of Zuckerman's (1994) SSS-V (Beauducel, Strobel \& Brocke, 2003). This scale investigates the intensity by which individuals strive for new, diverse and intense sensations or experiences (Zuckerman, 1979). The scale correlates with numerous risky behaviours and hobbies including alcohol and drug abuse which were not recorded in this study. The SSS-V contains four subscales. Thrill and Adventure Seeking describes the tendency for individuals to participate in risky physical activities. Disinhibition records the tendency towards socially or sexually uninhibited behaviour, Experience Seeking 
illustrates the search for novel experiences through a non-conformistic lifestyle, and finally Boredom Susceptibility measures the aversion to routine (Zuckerman, 1994). A total of 40 items were presented in the format of forced choice opposite statements. High scores on each subscale point towards high tendencies for each measure. Additionally, a total overall score for Sensation Seeking was calculated by summing up the scores for all 40 items.

In order to assess individual mating strategies, the Simpson's Sociosexual Orientation Inventory (SOI) was used (Simpson, 1998; Simpson \& Gangestad, 1991). This inventory measures the disposition of individuals towards promiscuity or the willingness to engage in uncommitted sex which is a key factor in relation to mating behaviour. High scores indicate a more promiscuous, unrestricted strategy, whereas individuals with low scores generally follow a more monogamous, restricted strategy (Gangestad \& Simpson, 2000). The inventory contains seven items. The first three are open questions which aim to capture expressions of sociosexual variation including number of different sexual partners in the past year. Item four measures covert sexual behaviour through statement ratings on an 8-point scale ranging from 1 ('never') to 8 ('at least once a day'). Item five to seven are also statements that need to be rated. They record sociosexual attitudes. All three attitudinal items were scored on 9-point scale ranging from 1 ('I strongly disagree') to 9 ('I strongly agree') and accumulated constitute the subscale Attitude. All items comprise the SOI index (for detailed description see, Simpson \& Gangestad, 1991).

The sex roles of the individuals sampled were investigated by using the Bem Sex Role Inventory (BSRI, Bem, 1974). The BSRI is a self-report measure of the individual's identification with personality traits that are traditionally associated with stereotypical masculine and feminine sex roles (Bem, 1974; Schneider-Dueker \& Kohler, 1988). It contains three subscales, the Femininity Scale, 20 items associated with stereotypical feminine traits, the Masculinity Scale, 20 items associated with stereotypical masculine traits and filler items (i.e. neither stereotypical masculine nor feminine characteristics). Scores were added up for each subscale, resulting in separate values for levels of femininity and masculinity for each participant.

The last psychometric scale used was the 'Fragebogen zur Beurteilung des eigenen Koerpers' ('Questionnaire on the Perception of One's Own Body') (Strauß \& Appelt, 1996). 
The attitude of participants towards their own body and physical appearance is assessed on four different subscales. The first subscale, Attractiveness and Self-confidence, mainly describes satisfaction with one's own appearance. The second subscale, Accentuation of Physical Appearance, investigates personal emphasis on caring for one's own body. The third subscale, Self-consciousness, indicates tendencies towards lack of self-control in relation to one's own body. The last subscale, Feeling Uncomfortable with Body/Sex, summarises aspects of shameful sensations in sexual contexts. The entire questionnaire contains 52 items in a yes/no format and is one of the most commonly used body perception questionnaires in Germany (Brähler, Strauß, Hessel \& Schumacher, 2000).

\section{Statistical analyses}

Internal consistencies (Cronbach's alpha) of all applied personality scales were calculated separately for the modified and non-modified sample. Replicated Goodness of Fit Tests (G-statistics) were conducted following Sokal and Rohlf (1981) to compare frequencies of demographic data and ornamentation details with adjusted $p$ values for multiple comparisons. A multivariate analysis of covariance (MANCOVA) with the between-subjects factor sex (male, female) and prevalence of body modification (modified, non-modified) was calculated for all psychometric scales. A multivariate design was chosen to minimize Type 1 error effects of multiple comparisons. Due to the fact that an age difference was shown between groups and reliable correlational relationships with several personality scales were obtained, age served as a covariate. All reported correlation coefficients are Pearson's correlations. Multiple regression analyses were performed to assess the significance of each predictor variable in greater detail.

Analyses of similarity/dissimilarity of profiles of mean personality scores were performed by Mahalanobis distances (see Maronna, 1976), which were computed for all nonmodified, only-tattooed, only-pierced individuals and those with both types of modification. The distances provide a measure of profile differences of related variables. 


\section{Results}

\section{Demographics}

Our sample included participants ranging from 18 to 59 years (mean and standard deviation (SD): $28.5 \pm 8.6$ years). The mean age for non-modified individuals was $30.6 \pm 10.2$ years, whereas body-modified participants were significantly younger (mean $27.3 \pm 7.2$ years; $\left.t_{357}=3.6, p<0.001\right)$. A replicated test for goodness of fit revealed that a significantly larger proportion of non-modified subjects had a university degree $\left(G_{1}=7.5, p<0.01\right)$. Subjects with Hauptschulabschluss, as well as those still in and without education had to be excluded from this analysis due to small sample size. Only $44 \%$ of the subjects stated to be a member of a subculture but the proportions of modified and non-modified participants with and without such an affiliation did not differ significantly $\left(G_{1}=1.0, p>0.1\right)$. The vast majority of participants (92\%) indicated to be heterosexual. Modified and non-modified participants did not differ regarding their sexual orientation $\left(G_{1}=3.2, p>0.1\right)$. Overall, $46 \%$ of the participants were in a serious relationship, $34 \%$ were singles, $10 \%$ reported to have an affair and 10\% were married. There was no significant difference between modified and nonmodified participants with respect to their relationship status $\left(G_{3}=2.4, p>0.1\right) .5 .3 \%$ of all participants indicated to perform 'uncommon' sexual practices. The occurrence of such practices was equally distributed among modified and non-modified individuals $\left(G_{1}=2.3, p>\right.$ $0.1)$.

\section{Body ornaments}

The mean age for the acquisition of a first tattoo was $22.04 \pm 7.03$ with a range from 12 to 57 years. The mean number of tattoos per individual in our sample was $2.7 \pm 0.28$, ranging from a single tattoo to 23 tattoos with a median of 1 . The surface area covered by tattoos ranged from $0.3 \%$ to $54.6 \%$ of total body surface with a median of $2.8 \%$. The size of single tattoos ranged from a body coverage of $0.2 \%$ to $18 \%$ with a median of $1.5 \%$. An effect of sex was found for the number of tattoos and for the percentage of covered body surface area. Men $(3.5 \pm 0.50, \mathrm{Mdn}=2.0)$ had significantly more tattoos than women $(1.9 \pm 0.29$; $\left.\operatorname{Mdn}=1.0 ; t_{156}=3.0, p<0.01\right)$. Furthermore, the mean body surface area covered by tattoos was larger for men $(10.3 \pm 1.48 \%, \mathrm{Mdn}=5.2 \%)$, than when compared to that of women $(4.3$ $\left.\pm 0.86 \% ; \operatorname{Mdn}=1.5 \% ; t_{156}=3.6, p<0.001\right)$. 
Tattoo designs were dominated by the category 'tribals', $30.1 \%$ of all tattoos. Other common designs were 'animals and nature' (11.1\%) and lettering tattoos (8.0\%). Figure 4.1 depicts the distribution of tattoo designs as a function of sex. Statistically significant differences between men and women concerning tattoo designs were found in the frequency of 'skulls, skeletons, daggers and knives' $\left(G_{1}=6.5, p<0.05\right)$ as well as 'old school' designs $\left(G_{1}=5.7, p<0.05\right)$, with men having more tattoos in these categories than women. However, women had significantly more 'flower' tattoos than men $\left(G_{1}=10.7, p<0.05\right)$. Statistical analyses did not reveal any further sex difference with respect to other tattoo designs (for all comparisons $p>0.1$ ). Further investigation into the relation between tattoo design and personality was not possible due to small sample sizes within design categories.

The most common locations for tattoos were upper arms (29.1\%), shoulders (14.2\%) and lower legs (12.5\%). The distribution of the locations as a function of sex is illustrated in Figure 4.2. Men were more often tattooed on upper arms than women $\left(G_{1}=13.8, p<0.01\right)$. Women, however, had significantly more tattoos on the lower back $\left(G_{1}=13.3, p<0.01\right)$, as well as in the preabdominal (genital), and backside regions (bottom; $G_{1}=6.7, p<0.01$ ). No additional significant sex difference could be detected (for all comparisons $p>0.1$ ).

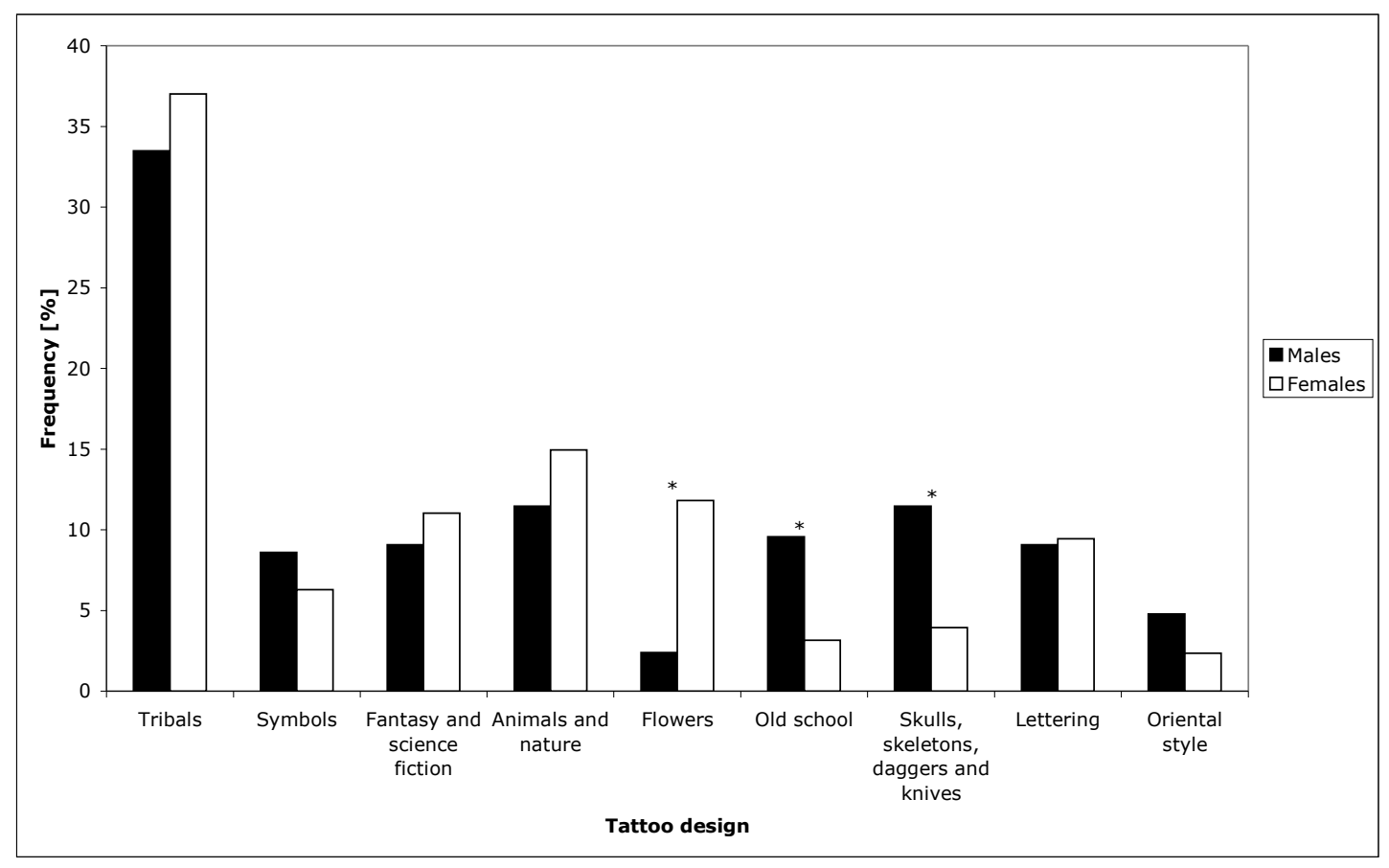

Figure 4.1 Sex differences in tattoo design. Significant differences are indicated by $*(p<0.05)$. 
Among pierced participants, the mean number of piercings was $2.9 \pm 0.25$, with a range from 1 to 18 and a median of 1 . The mean age for the acquisition of the first piercing was $20.48 \pm 6.77$ ranging from 12 to 52 years. Men $(3.5 \pm 0.52 ; \mathrm{Mdn}=1)$ had a larger average number of piercings than women $\left(2.3 \pm 0.18 ; \operatorname{Mdn}=1 ; t_{156}=2.5, p<0.01\right)$. The prevailing type of jewellery used by both sexes (73.1\%) was 'standard rings or barbells'. 'Decorated rings or barbells' were also commonly used (23.0\%). A significant sex difference existed for the latter, with women wearing more decorated jewellery (31.6\%) than men $\left(14.2 \% ; G_{1}=15.1, p<0.01\right)$. Other jewellery categories (twisters, flesh tunnels, and plugs) were only recorded sporadically and no further reliable sex differences could be found.

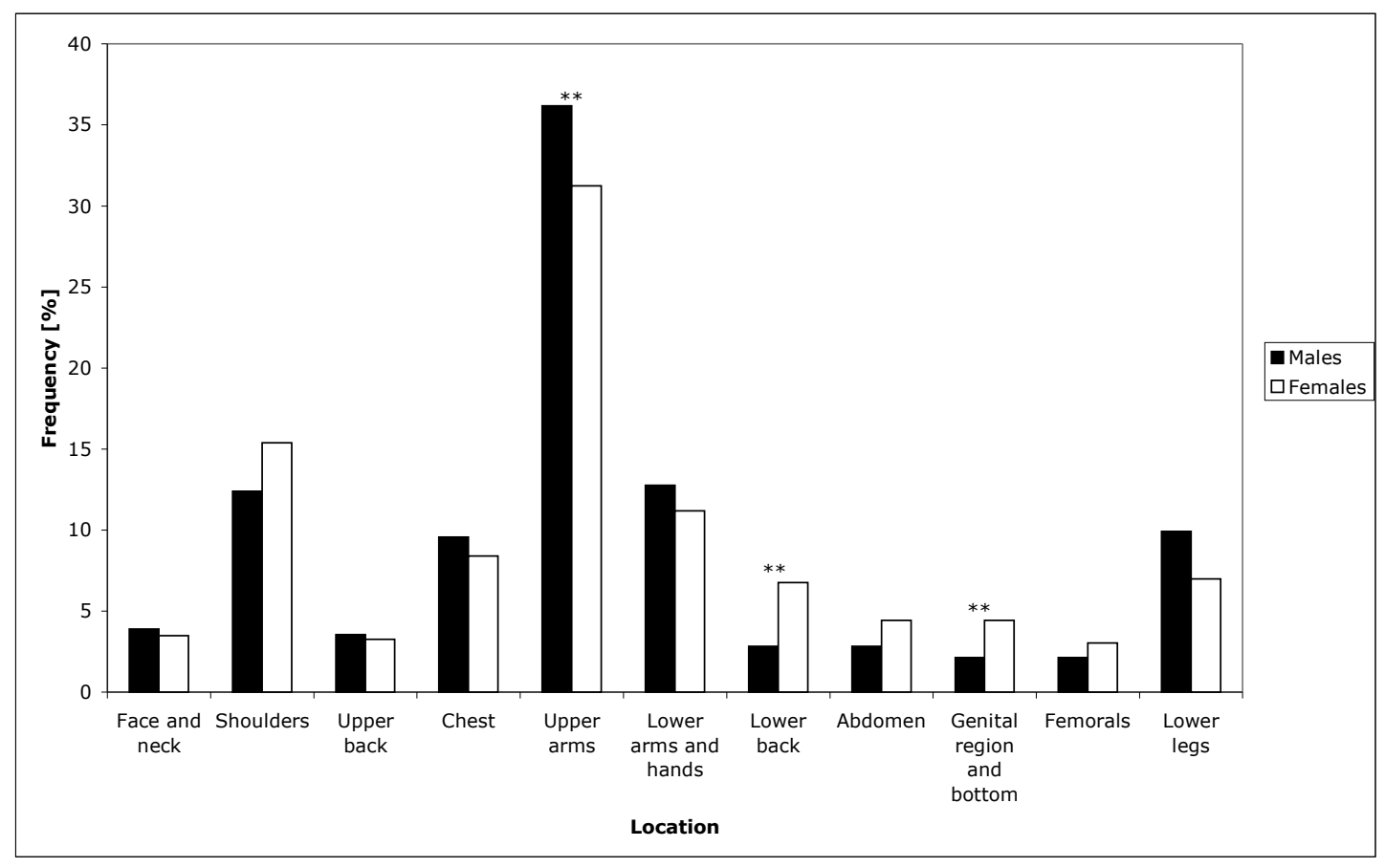

Figure 4.2 Sex differences in tattoo location. Significant differences are indicated by $* *(p<$ $0.01)$ and by $*(p<0.05)$.

Piercings were most prevalent on ears $(18.4 \%)$ even though no conventional earrings were recorded. Other common locations were the belly button $(14.9 \%)$, genitals $(12.7 \%)$, tongue $(11.6 \%)$, lips $(11.4 \%)$, acromastium $(10.9 \%)$, nose $(10.2 \%)$, and eyebrows $(8.8 \%)$. Figure 4.3 shows the frequency distribution of piercing location as a function of sex. The examination of sex differences revealed that men had significantly more piercings in the eyebrows $\left(G_{1}=4.1, p<0.05\right)$ and genitals $\left(G_{1}=6.0, p<0.05\right)$ than women. Women more often pierced their noses $\left(G_{1}=12.8, p<0.01\right)$ and belly buttons $\left(G_{1}=11.9, p<0.01\right)$. 


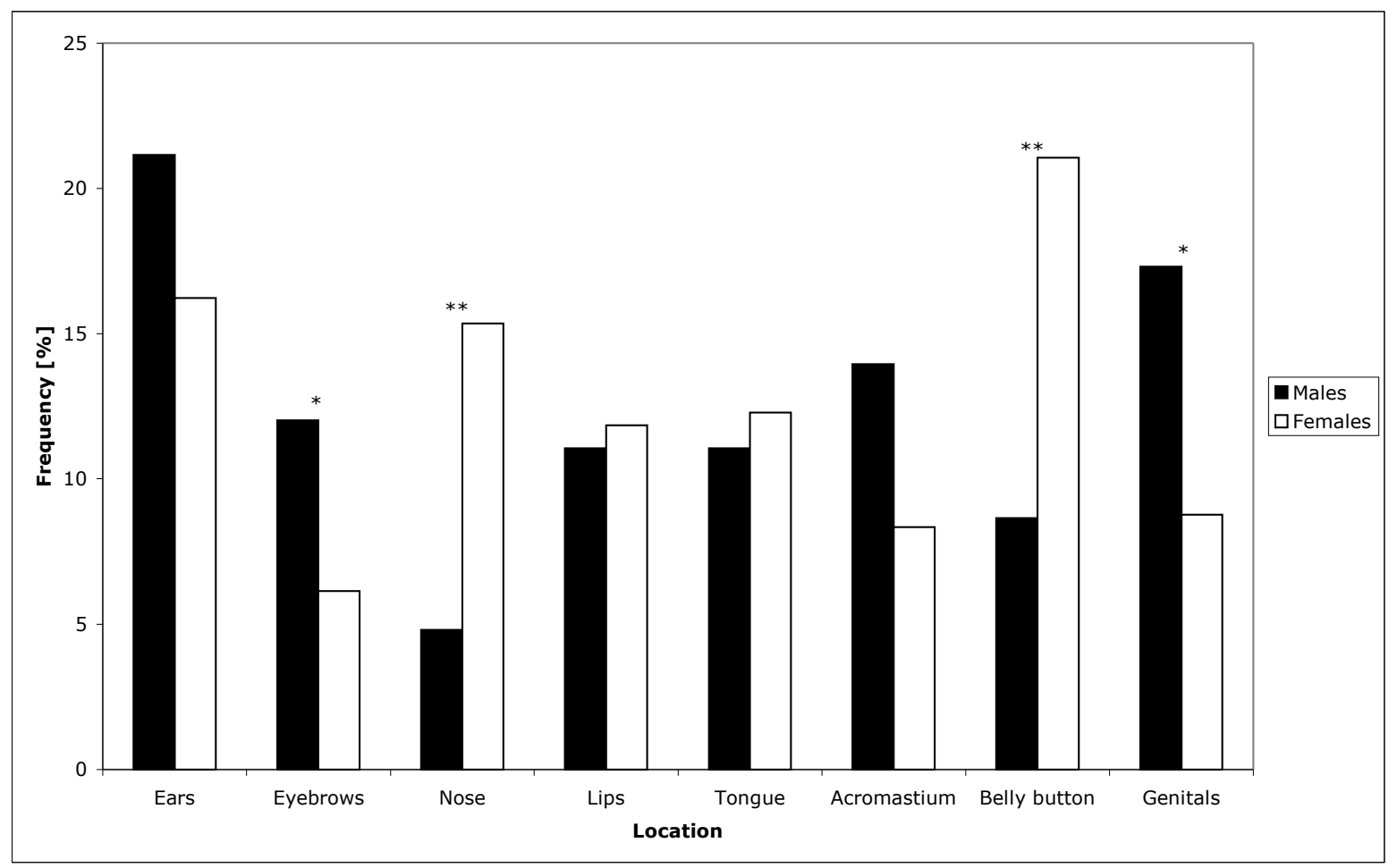

Figure 4.3 Sex differences in piercing location. Significant differences are indicated by $* *(p<$ $0.01)$ and by $*(p<0.05)$.

\section{Personality scales}

\section{Intercorrelations}

The correlation coefficients among personality scales are presented in Table 4.2. There are also numerous correlations between the inventories' subscales, which we do not discuss in detail. However, since some reliable correlational relationships were important for later considerations we highlight the following. There are significant positive correlations between the Sensation Seeking subscales and Sociosexual Orientation ( $r$ s ranging from 0.11 to 0.58 , all $p \mathrm{~s}<0.05)$ as well as a negative correlation of the latter to the BFI subscale Agreeableness ( $r$ s ranging from -0.15 to -0.17 , all $p$ s $<0.05$ ).

The internal consistencies for the applied scales ranged from 0.53 to 0.88 (see Table 4.2). Cronbach's alpha coefficients did not differ significantly between non-modified and modified individuals (for all comparisons $t s<1.0$ ). Hence, group differences reported in the following could not be explained by differences in reliabilities. 
Table 4.2 Correlation coefficients among personality inventories $(\mathrm{N}=359)$. The diagonal contains the internal consistencies (Cronbach's alpha) of each scale separately computed for the group of non-modified / modified.

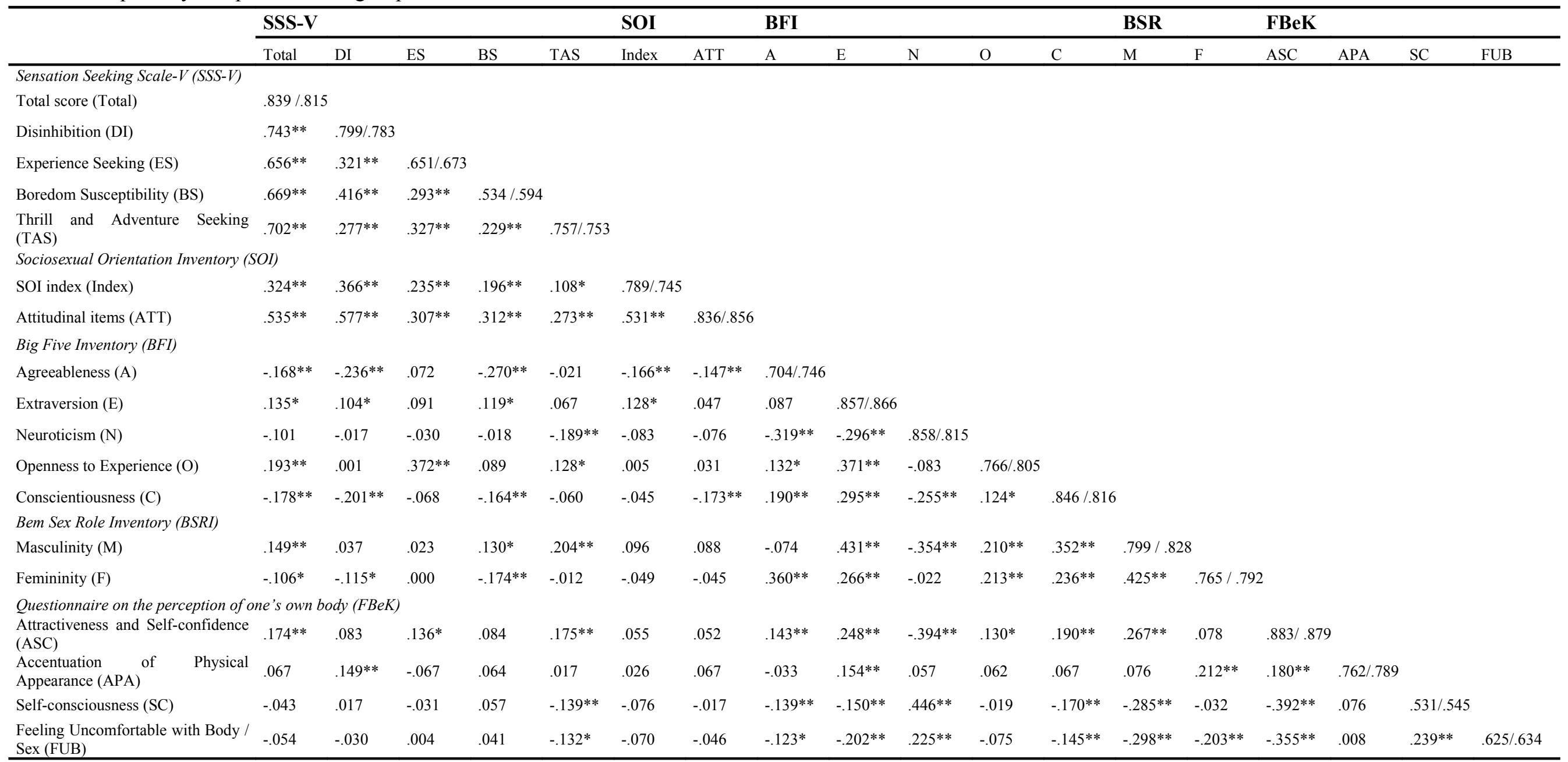

Note. ${ }^{*} \mathrm{p}<.05$ (two-tailed); $* * \mathrm{p}<.01$ (two-tailed) 


\section{Non-modified versus body modified}

Differences in personality scales between body-modified (tattooed and/or pierced) individuals and the non-modified control group, summarised in Table 4.3, show means and SDs for all personality scales. Since we found a significant age difference between bodymodified and non-modified, as well as significant correlational relationships between age and personality scales, age was included as a covariate in the subsequent MANCOVA. There were a number of negative correlations with age: the SSS-V with all its subscales, the subscale 'Attitude' of the SOI and two subscales of the Questionnaire on the Perception of one's Own Body (ranging from $r=-0.13$ to $r=-0.28$; all $p$ s $<0.05$ ). Conscientiousness, a subscale of the BFI, however, showed a positive correlation $(r=0.18, p<0.05)$ with age. Sex differences were also obtained for nearly all personality scales. Interactions of body modification and sex, which would have been of great interest for the present question, were not found. For the sake of brevity, we do not present all main effects of the factor sex and the effects of the covariate age because both were not the focus of the present study.

The results of the MANCOVA showed a significant effect of the factor body modification $\left(F_{17,337}=2.249, p<0.01\right.$, Wilks $\left.\Lambda=0.898\right)$ and $\operatorname{sex}\left(F_{17,337}=10.840, p<0.001\right.$, Wilks $\Lambda=0.646$ ) on the personality scales. The interaction of the between-subject factors did not reach the required statistical level of significance $\left(F_{17,337}=0.614, p>0.1\right.$, Wilks $\Lambda=$ 0.970). To identify the personality factors responsible for the significant result on body modification we additionally analysed the between-subject effects separately for each applied psychometric scale. Results should be viewed with caution due to possible effects of accumulating alpha-error with multiple comparisons. 
Table 4.3 Mean and standard deviation (S.D.) of all personality scales as a function of body modification $(\mathrm{N}=359)$.

\begin{tabular}{|c|c|c|c|c|c|c|c|}
\hline & \multicolumn{2}{|c|}{ Non-modified } & \multicolumn{2}{|c|}{ Body-modified } & \multirow[b]{2}{*}{$F$ value } & \multirow[b]{2}{*}{$P$} & \multirow[b]{2}{*}{$\eta^{2}$} \\
\hline & Mean & S.D. & Mean & S.D. & & & \\
\hline \multicolumn{8}{|l|}{ Sensation Seeking Scale-V } \\
\hline Total value & 20.6 & 6.6 & 22.4 & 6.0 & 5.7 & .018 & .014 \\
\hline Disinhibition & 4.5 & 2.6 & 5.2 & 2.4 & 5.4 & .020 & .015 \\
\hline Experience Seeking & 6.3 & 2.0 & 7.0 & 1.7 & 9.8 & .002 & .027 \\
\hline Boredom Susceptibility & 4.0 & 2.1 & 4.0 & 2.0 & .001 & .978 & .000 \\
\hline Thrill and Adventure Seeking & 5.8 & 2.6 & 6.1 & 2.6 & .90 & .344 & .003 \\
\hline \multicolumn{8}{|l|}{ Sociosexual Orientation Inventory } \\
\hline SOI index & 40.2 & 43.1 & 56.0 & 58.7 & 11.0 & .001 & .030 \\
\hline Attitude & 4.0 & 2.4 & 4.7 & 2.4 & 9.1 & .003 & .025 \\
\hline \multicolumn{8}{|l|}{ Big Five Inventory } \\
\hline Agreeableness & 27.3 & 4.4 & 26.1 & 4.9 & 5.5 & .019 & .015 \\
\hline Extraversion & 28.1 & 6.0 & 29.0 & 6.0 & 1.1 & .291 & .003 \\
\hline Neuroticism & 21.6 & 6.1 & 23.1 & 6.0 & 2.6 & .111 & .007 \\
\hline Openness to Experience & 36.2 & 6.1 & 37.0 & 6.4 & 1.0 & .316 & .003 \\
\hline Conscientiousness & 27.5 & 5.7 & 28.1 & 5.5 & 2.1 & .153 & .006 \\
\hline \multicolumn{8}{|l|}{ Bem Sex Role Inventory } \\
\hline Masculinity & 92.1 & 19.9 & 93.0 & 14.5 & .63 & .428 & .002 \\
\hline Femininity & 92.5 & 16.3 & 94.2 & 12.6 & .51 & .478 & .001 \\
\hline \multicolumn{8}{|c|}{ Questionnaire on the perception of one's own body } \\
\hline Attractiveness and Self-confidence & 11.3 & 3.9 & 11.2 & 3.8 & .000 & .985 & .000 \\
\hline Accentuation of Physical Appearance & 6.6 & 2.6 & 7.3 & 2.3 & 2.1 & .144 & .006 \\
\hline Self-consciousness & 3.7 & 2.7 & 4.2 & 3.2 & .57 & .452 & .002 \\
\hline Feeling Uncomfortable with Body / Sex & 1.5 & 1.4 & 1.7 & 1.4 & 1.13 & .250 & .004 \\
\hline
\end{tabular}

Note. $\eta^{2}=$ effect size 
Groups differed significantly in the total score of Sensation Seeking with body-modified participants having higher scores $\left(F_{1,354}=5.7, p=0.019\right)$. The comparison of the subscales of SSS-V also revealed significantly higher scores in Disinhibition $\left(F_{1,354}=5.4, p=0.020\right)$ and Experience Seeking $\left(F_{1,354}=9.8, p=0.002\right)$ in body modified participants. Regarding Boredom Susceptibility and Thrill and Adventure Seeking, we found no differences (all $p$ s $>$ 0.1). A highly significant difference could be established with respect to Sociosexual Orientation with body-modified participants having higher SOI index scores $\left(F_{1,354}=11.0, p\right.$ $=0.001)$. They also had higher values on the SOI subscale Attitude $\left(F_{1,354}=9.1, p=0.003\right)$. Comparable to previous analyses on the SOI score, standard deviations were quite high (cf. Schmitt, 2005, p.263). The analysis also revealed a significant difference in Agreeableness $\left(F_{1,354}=5.5, p=0.019\right)$, with body modified participants exhibiting lower Agreeableness scores. There were no statistically significant differences between the groups on the Femininity Scale or Masculinity Scale of BSRI (all $p \mathrm{~s}>0.1$ ). Body modification also had no reliable effect on how individuals view their own body (all $p \mathrm{~s}>0.1$ ). No interaction between body modification and sex could be determined for any of the applied personality scales (for all, $p \mathrm{~s}>0.1)$.

\section{Types of modification}

We conducted profile comparisons to investigate the relationship between the different types of body modification and personality characteristics. Figure 4.4 depicts group profiles for the personality scales in terms of $z$ values for all four types of body modification. The similarity of these profiles was compared via Mahalanobis distances. Significant profile distances appeared between the group of individuals with both types of modification and the three other groups, that is, only-tattooed (4.16, $p<0.01)$, only-pierced $(2.87, p<0.01)$, and non-modified individuals $(2.62, p<0.01)$. Smaller distances that did not reach the conventional $5 \%$ level of significance were obtained between the profiles of only-tattooed and non-modified $(1.54, p>0.1)$, as well as only-tattooed and only-pierced individuals $(1.27, p>$ 0.1). The highest similarity emerged between only-pierced and non-modified individuals $(0.26, p>0.1)$. 


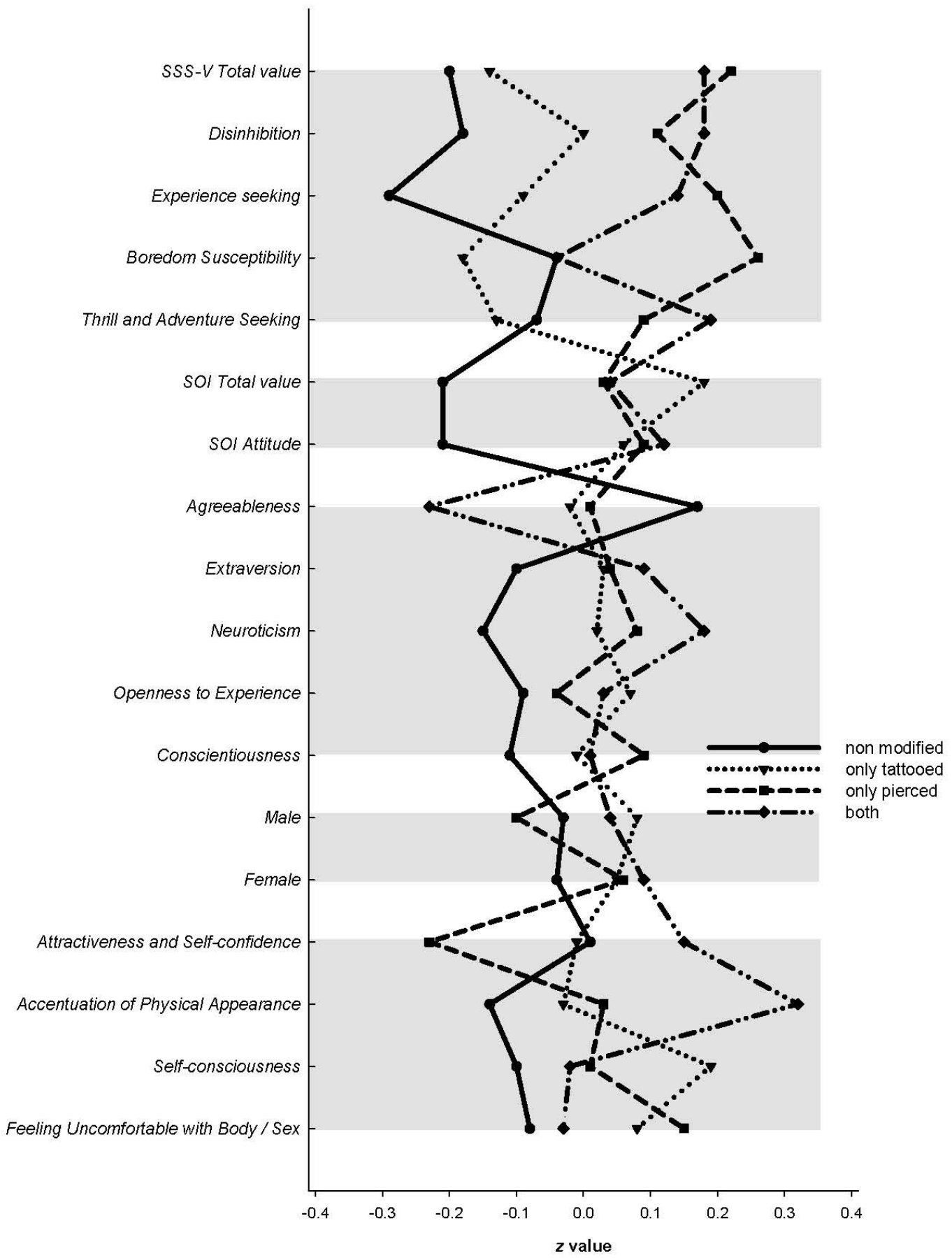

Figure 4.4 Profiles for the different types of body modification in terms of $z$ transformed group means of all personality scales. The gray fields mark the entire subscale of a psychometric inventory. 


\section{Degree of modification}

We also examined whether personality type correlates with the degree of body modification by conducting stepwise regression analyses between personality variables and the number of tattoos and piercings, respectively. Although the degree of modification in the case of tattoos might be better expressed by the body surface they cover, we used number of tattoos in further analyses because the number of tattoos was strongly correlated with the percentage of covered body surface $(r=0.90, p<0.001)$. The most powerful predictor of both number of tattoos and number of piercings was sex which accounted for $5.4 \%$ of the total variance in tattoos $\left(F\right.$ change $\left.=8.9 ; R^{2}=0.05 ; p<0.003\right)$ and $3.3 \%$ in piercings $(F$ change $=$ 5.1; $\left.R^{2}=0.03 ; p<0.025\right)$, with men having more tattoos and more piercings than women. For piercings, there was no other predictor variable, whereas for tattoos, an additional predictor variable was Thrill and Adventure Seeking. This allowed us to increase the explained variance to $11.9 \%$ ( $F$ change $\left.=11.3 ; R^{2}=0.12 ; p<0.001\right)$. Higher scores in Thrill and Adventure Seeking were associated with a decreasing number of tattoos $(r=-0.18 ; p<0.05)$.

\section{Discussion}

\section{Socio-demographic characteristics}

The major goal of the present study was to examine potential differences in personality traits of body-modified individuals in order to discuss possible social signaling functions of modern body modification. With respect to socio-demographic variables, we found no differences between body-modified and non-modified subjects in subcultural membership, relationship status, sexual orientation and 'uncommon' sexual practices. Ornamented individuals were on average only slightly younger than non-ornamented individuals. In terms of education, ornamented individuals were less likely to have a university degree, however, there was no difference on all other educational levels. This lack of pronounced differences in socio-demographic variables is surprising especially given that tattooing and piercing were found to be associated with deviant and risky behaviours (e.g. Birmingham, Mason \& Grubin, 1999; Carroll et al., 2002) and certain subcultural movements (e.g. Pitts, 2003; Sanders, 1989) in previous studies. To the extent that our convenience sample allows extrapolation, this homogeneity attests to the fact that tattoos and piercings 
have indeed penetrated all levels and classes of German society and that they are no longer restricted to various subgroups. Such a recent shift in social use and numerical prevalence of tattoos and piercings has also been documented in other societies (DeMello, 1995; 2000). The possibility that sampling bias due to partly different recruitment methods might have affected our results can be tested in future studies that employ uniform sampling methods.

\section{Associations with individual personality traits and their implications}

Our study revealed several differences between body-modified and non-modified individuals in general personality characteristics. A profile analysis revealed differences between individuals with both types of modifications, compared to individuals with only tattoos, only piercings or no modification. Most similar personality profiles were obtained for individuals without body modification and those with only piercings. This seems intuitive especially given the lack permanence of piercings. They can be easily removed and thus, do not require the same level of commitment as a permanent tattoo. Nevertheless, we discuss tattoos and piercings together under the term body modification below as a more detailed differentiation did not change or add major points of interest to the general results.

\section{Sex Role Orientation, Big Five, and Perception of one 's Own Body}

Although tattooing has often been considered as a masculine activity (DeMello, 1993; Sanders, 1989), the participant's Sex Role Orientations (Bem, 1974), that is, the preference of stereotypic feminine or masculine behaviour, did not differ between body-modified and nonmodified individuals. These findings were unexpected and might indicate a shift in sex role attitudes regarding body modification. Furthermore, no group differences could be discerned for four of the basic personality dimensions of the Big Five model of personality. Contrary to the findings of this study, Nathanson et al. (2006) found Openness to Experience to be a predictor of cultural deviance markers. This might be a sampling effect because the participants of the latter study were all undergraduate students. However, as in our study, Nathanson et al. (2006) failed to reveal effects of Extraversion, Neuroticism and Conscientiousness. 
We found no differences in the participant's self-ratings of Attractiveness and Selfconfidence, Self-consciousness, Accentuation of Physical Appearance and Feeling Uncomfortable with Body/Sex, which are the subscales of the Questionnaire on the Perception of one's Own Body. This finding is also surprising because several authors describe cases of individuals who obtained body art in order to increase self-esteem and subjective beauty (e.g. Atkinson, 2002; Schildkrout, 2004).

Our data, however, revealed that participants with body modifications exhibited lower scores in Agreeableness. People having lower scores in Agreeableness are characterised as quarrelsome, less trusting, cold and unkind. The lower scores might result from their tendency to signal nonconformist behavior. Delazar (2005) supports this interpretation by reporting lower Agreeableness scores for individuals planning to acquire a piercing.

\section{Sensation Seeking and Sociosexual Orientation}

Group differences were found for Sensation Seeking such that individuals with body modifications showed higher scores on the subscales Disinhibition and Experience Seeking. These findings are consistent with a recent study of college students where sex and Sensation Seeking were established as reliable predictors of number of piercings (Roberti et al., 2004). Additional regression analyses of our data also revealed Thrill and Adventure Seeking, in combination with sex, as reliable predictors for number of tattoos. However, Thrill and Adventure Seeking was negatively correlated with the number of tattoos in our study, contradicting the findings of Roberti and colleagues. This might also be a sampling effect. Roberti based his analysis on college students with a mean age of $20.6 \pm 1.73$ for males and $19.70 \pm 1.50$ for females. In our sample, the mean age was much higher, at $29.1 \pm 7.9$ for males and $27.3 \pm 9.0$ for females. When considering the age of acquisition of the first body modification, which in our sample was 22 for tattoos and 20 for piercings, it appears that Thrill and Adventure Seeking might be specifically relevant for attaining the first body modification. However, Disinhibition and Experience Seeking appear to be more stable predictors of body modification.

We also revealed differences in sociosexuality such that body-modified subjects had higher scores and thus a more unrestricted Sociosexual Orientation than non-modified 
participants. Individuals with high scores in Sociosexual Orientation are typically male and exhibit behaviours that are more promiscuous and reflect short-termed mating goals (Gangestad \& Simpson, 2000; Schmitt, 2005). Because body-modified individuals had significantly higher SOI scores, their body modifications may provide indicators of their behavioural predispositions for potential mates in this respect.

A link between body ornamentation and mating behavior was also indicated by the higher scores in Sensation Seeking. Sensation seeking is a trait defined by the seeking of varied, novel, complex and intense sensations and experiences and the willingness to take physical, social, legal and financial risks for the sake of such experience. Zuckerman (1994) also emphasised that Sensation Seeking has biological correlates including heritability. It is related to sexual and mating behavior, as indicated, for example, by higher similarity in the amount of Sensation Seeking in partners of functioning marriages (e.g. Farley \& Davis, 1977; Ficher, Zuckerman \& Steinberg, 1988). Besides sexual interest (Zuckerman, Bone, Neary, Mangelsdorf \& Brustman, 1972; Zuckerman, Tushup \& Finner, 1976), Sensation Seeking has been shown to be linked to other aspects of life such as preferences for types of sport (Zuckerman, 1983), music (Litle \& Zuckerman, 1986), and media programs (Brown, Ruder, Ruder \& Young, 1974; Zuckerman \& Litle, 1986), which might explain that a match in the amount of Sensation Seeking between partners is an important predictor for functioning relationships. Hence, Sensation Seeking reflects an individual's basic attitudes and values which are crucial in mate choice (Zuckerman, 1984; 1994). High Sensation Seeking scores may also be a prerequisite for obtaining a body modification because of both the physical risks and side effects of the latter. Thus, tattoos and piercings may signal the bearer's level of Sensation Seeking, also in the context of mate choice. However, Sensation Seeking and Sociosexual Orientation correlate positively and appear to be interdependent. Therefore, the two variables should be considered in combination. 


\section{Body modifications as signals in social interactions}

A previous cross-cultural study of body modifications provided indirect evidence for a signaling role of body modification in sexual selection based on a relationship between the prevalence of body modification in males and polygyny (Ludvico \& Kurland, 1995). Singh and Bronstad (1997) examined the same cross-cultural sample to investigate the relationship between prevailing body modification and the prevalence of pathogens. Their expectations were explicitly based on the handicap principle (Zahavi, 1975). Singh and Bronstad (1997) found that in geographic regions with a high pathogen load, invasive body modification practices were prevalent especially among women and on specific locations of their bodies. This suggests that body modification may serve as a handicap.

In our sample, body modified individuals differed from those without body modification in Sensation Seeking, Sociosexuality, and Agreeableness. All three traits have functional consequences in the context of mate choice as well as other social interactions (e.g. Grammer, Fink, Møller, \& Thornhill, 2003). They reflect basic attitudes and values as well as high pain and risk tolerance levels (Stirn, 2004b). One testable prediction from our study is that body modifications might code for these traits such that persons with tattoos or piercings should be perceived as less Agreeable and greater Sensation Seekers with a more unrestricted Sociosexual Orientation. This is a subject for future research.

Signals acting in sexual selection should show within-sex variation and sexual dimorphism (Snowdon, 2004). These criteria were met by our analyses which revealed that the typical male tattoo design comprised skulls, skeletons, daggers and knives, whereas women preferred flower tattoos. Nevertheless, variability within sexes, especially in design and location, was considerable. Men had generally more tattoos and piercings also suggesting a signaling function of body modification in the context of mate choice or mating competition. Furthermore, men and women seemed to highlight their secondary sexual characteristics with body modification. Men were mainly tattooed on their arms, whereas women had more tattoos in their preabdominal and backside regions. These patterns may draw attention to the male's shoulder to hip ratio and the female's waist to hip ratio, both criteria in assessing physical attractiveness (Maisey, Vale, Cornelissen \& Tovée,1999; Singh, 1983). Men had more piercings in eyebrows, whereas women were pierced more often in their 
belly buttons and noses. Prominent eyebrows in men are considered attractive by women (Perret et al., 1998; Thornhill \& Gangestad, 1999). They are found to signal high levels of testosterone and, thus, immunocompetence (Folstad \& Karter, 1992; Thornhill \& Møller, 1997). The nose is a major criterion for evaluating female facial attractiveness (Jones, 1996).

A highly valued characteristic in women is also a flat abdomen as this signals fertility (Grammer et al., 2003). The positioning and sex differences in designs therefore provide no $a$ priori reason to reject the hypothesis of a signaling function of tattoos and piercings in the mating context. Our study therefore provides a basis for studying the effects of tattoos and piercings on members of both sexes within the framework of sexual selection theory.

\section{Conclusions}

Body ornaments are no longer restricted to particular socio-demographic subgroups. This recent change in prevalence of body modification fits with differences in several personality traits between body-modified people and others without body modifications. The average tattooed and/or pierced individual is more likely to be a Sensation Seeker, as well as to possess a more unrestricted sexual attitude, generally having more sexual partners in short term relationships than the average non-ornamented individual. These personality traits might be of relevance in assessing potential mates and thus ornaments could provide important cues about personality in this context. Trait characteristics of tattoos and body piercings support this hypothesis. However, the results of this questionnaire survey are still limited. Due to the convenience sample, general interpretations should be viewed with caution. Furthermore, we did not directly assess the influence of body modification on social interactions such as mate choice and intrasexual competition. Nevertheless, this study has generated several testable predictions about potential signaling functions of tattoos and piercings in human social interactions especially in the mating context. 


\section{Chapter 5}

\section{Human body modification: testing the signaling quality of tattoos}

Silke Wohlrab*, Bernhard Fink*, Peter M. Kappeler*o \& Gayle Brewer ${ }^{+}$

* Abteilung Soziobiologie / Anthropologie der Universität Göttingen, Deutschland

○ Abteilung Verhaltensökologie und Soziobiologie, Deutsches Primatenzentrum, Göttingen, Deutschland

${ }^{+}$Department of Psychology, University of Central Lancashire, Preston, United Kingdom 


\begin{abstract}
The enhancement of physical attractiveness through body ornaments, such as tattoos, has recently become very popular in Westernized societies. Evolutionary psychologists have suggested that these invasive body modifications could possibly act as handicap signals in sexual selection. However, knowledge about the signaling quality of body modification and its perception is scarce. In this present study a sample of 278 men and women rated images of tattooed and non-tattooed virtual human characters for perceived aggression, attractiveness, dominance, health, masculinity (male figures), and femininity (female figures). Tattooed male characters were perceived as more dominant, and tattooed female characters as less healthy compared with their non-tattooed counterparts. We discuss these results in view of a potential biological signaling function of tattoos in modern Western societies.
\end{abstract}




\section{Introduction}

The practice of tattooing has experienced a 'renaissance' in the 1980's (Gilbert, 1988) and has since then become increasingly popular in all age and social classes (Wohlrab, Fink \& Kappeler, 2005). Wohlrab, Stahl and Kappeler (2007) found that physical embellishment is one of the most frequently mentioned motivations for acquiring a tattoo, whereby people obtain tattoos for purely aesthetic reasons to beautify their body, and consider their tattoo as a fashion accessory or a piece of art. But are tattoos - as deliberate alterations of the skin - able to increase an individual's physical attractiveness purely for aesthetic reasons, or is there any biological signaling quality associated with tattoos, which may affect our perception of others, and which may have consequences for human mate selection?

Singh and Bronstad (1997) reported association between the prevalence of body modifications in cultures with different pathogen loads. They conducted a cross-cultural comparison, including seven species of pathogens, coding the pathogen load on a three level scale according to the regional severity of each pathogen. Pathogen load predicted female body modification (stomach scarification), irrespective of confounding factors such as polygyny, famine or social class stratification. Singh and Bronstad (1997) concluded that those body modifications could act as handicap signals (sensu Zahavi, 1975), because they were generally perceived to enhance attractiveness and attractiveness indicates mate quality in the sense of pathogen resistance.

Following this line of reasoning, one could assume that only high quality individuals might be able to afford invasive body modifications, due to the health risks associated with the practice of tattooing. Such risks include severe bacterial infections (Stirn, 2003a), transmission of blood borne diseases such as HIV (Kral et al., 2001) and hepatitis (Goldberg \& Anderson, 2004; Mariano et al., 2004), as well as allergic reactions to carcinogenic tattooing colors (Tsuruta et al., 2004). Aside from the prevalence data of Singh and Bronstad (1997) we know of no empirical evidence showing that body modifications are actually perceived as signals of quality in human mate choice. However, if tattoos act as handicap signals, resulting in greater body modification by high quality mates, we would expect tattooed individuals to be perceived more positively by potential mates. This absence of data in this area could be due to the fact that previous research has largely investigated the 
perception of tattooed individuals in terms of the cultural values that they could convey (e.g. Sanders, 1989).

The present study investigated people's perception of tattoos as by conducting a rating study, in which bodies of virtual figures with and without tattoos were rated on attributes that relate to male and female mate choice criteria. These attributes included physical attractiveness, health, dominance, physical aggression and masculinity or femininity (for men and women, respectively). One of the most accessible traits is that of physical attractiveness, which together with physical health is highly valued in mate choice because they signal aspects of an individual's physical quality (Gangestad \& Scheyd, 2005; Grammer et al., 2003). In addition, the perceived masculinity or femininity of a person is also associated with their desirability as a romantic partner. In particular, the femininity of a woman is highly valued by men because it indicates her fecundity (Grammer et al., 2003; Law-Smith et al., 2006). Men that appear to be dominant (Neave et al., 2003; Townsend, 1993) or masculine (Johnston et al., 2001), are regarded as attractive by women perhaps because dominant men usually achieve higher social status due to their greater ability to provide or defend the resources necessary for reproduction (Geary, Vigil \& Byrd-Craven, 2004) or because masculinity signals testosterone, one cue of physical fitness (Penton-Voak \& Chen, 2004; Thornhill \& Gangestad, 1999). However, extreme dominance (which may be expressed as aggressive behavior; Mazur \& Booth, 1998) can negatively influence reproductive success (Mueller \& Mazur, 1998) and might therefore be perceived as undesirable in potential mates.

We suggest that if body modification acts as a handicap signal, a number of positive traits should be attributed to tattooed compared to non-tattooed characters. Specifically, we hypothesized that if tattoos represent some positive signal of mate value, i) tattooed male and female characters should be rated as more attractive and ii) healthier than non-tattooed stimuli iii) tattooed male figures should be perceived as more dominant than non-tattooed figures although we do not expect this to extend to perceptions of aggressiveness iv) tattooed female / male figures to be rated v) more feminine / masculine than non-tattooed figures respectively. 


\section{Materials and Methods}

\section{Participants}

A total of 278 individuals, 145 men and 133 women between the ages of 18 and 39 years $($ mean age $=23.84$, S.D. $=2.97$, participated in the study. Participants - predominantly undergraduate college students - were recruited at the University of Goettingen.

\section{Stimuli}

Three male and three female virtual human characters were generated using the software Poser 6 (e-frontier, Scotty Valley, USA). Six characters were generated, three males and three females. Each figure was displayed with and without a tattoo. All characters wore bathing suits and were presented in a slightly rotated front view (see Figure 5.1). Tattoos were placed on the most typical location i.e. the arm and the calf for stimuli of both sexes. Additionally in one stimulus the tattoo was placed on the chest of the male and on the abdomen of the female stimulus, since sex-specific variations in the location of tattoos appear (Table 5.1; Wohlrab et al., in press). For both male and female characters, the most common category of tattoo ('tribals') was chosen (Wohlrab et al., in press). Typical tribal tattoos encompass bold, black, silhouette style designs and are characterized by symmetrically arranged rolling lines.

\section{Experimental setup}

Experiments were created using Media Lab Research Software (Empirisoft Inc., New York), with each experiment containing one male and one female stimulus. Stimuli were either both tattooed or both not tattooed, resulting in three experiments with tattooed stimuli and three with natural stimuli (Table 5.1). Experiments were presented in randomized order on a 17-inch flat screen (Iiyama ProLite E 4815) with a resolution of 1280 x 1024 pixels.

Each participant was randomly assigned to one of the six experiments and was given standardized instructions prior to data collection. All participants were requested to rate each figure on perceived aggression, attractiveness, dominance, health, and masculinity or femininity (for male or female stimuli, respectively) on a 7-point Likert scale (from 1 = 'not' to $7=$ 'very'). Attributes were presented in random order. 
non-tattooed

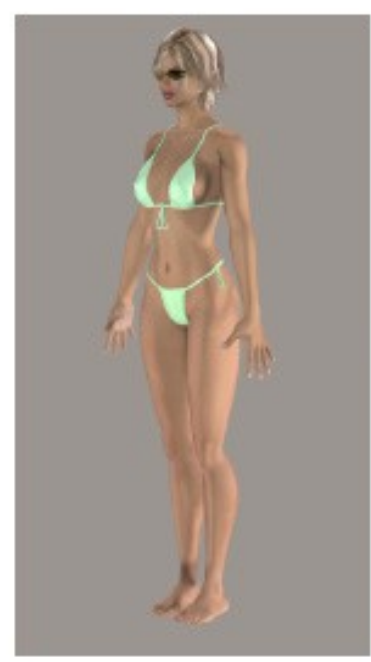

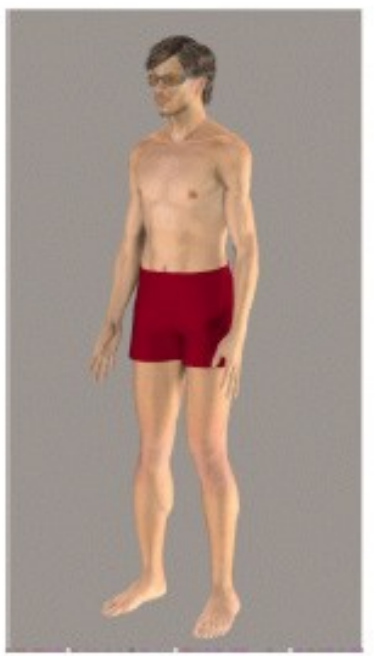

tattooed
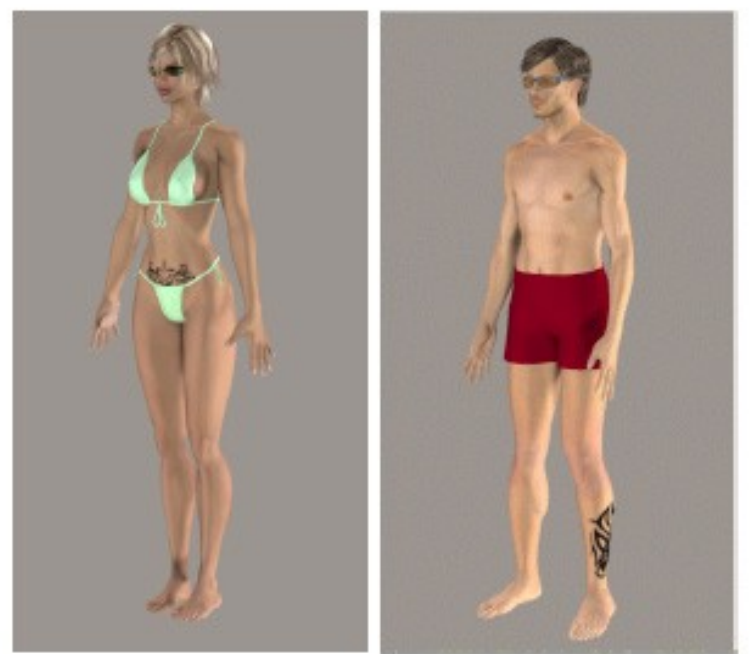

Figure 5.1 One male and one female stimulus figure, each with and without tattoo.

\section{Data analyses}

Inter-rater reliability was tested using Cronbach's alpha of internal consistency for each attribute. Values ranged from 0.77 (healthiness) to 0.97 (attractiveness). Group comparisons were conducted between tattooed and non-tattooed male as well as female figures for all attributes, using multiple ANOVA with the attributes aggression, attractiveness, dominance, health and masculinity (male figures) femininity (female figures) as dependent variables and stimulus condition (tattooed vs. non-tattooed) and sex of the rater as factors.

Table 5.1 Experimental setup.

\begin{tabular}{|c|c|c|c|c|c|}
\hline Experiment & Stimulus & Characters & Men & Women & $\mathbf{N}$ \\
\hline 1 & Tattooed & $\begin{array}{l}\text { Female } 1 \text {, tattoo on arm } \\
\text { Male 1, tattoo on arm }\end{array}$ & 24 & 21 & 45 \\
\hline 2 & Tattooed & $\begin{array}{l}\text { Female } 2 \text {, tattoo on calf } \\
\text { Male } 2 \text {, tattoo on calf }\end{array}$ & 22 & 22 & 44 \\
\hline 3 & Tattooed & $\begin{array}{l}\text { Female } 3 \text {, tattoo on abdomen } \\
\text { Male } 3 \text {, tattoo on chest }\end{array}$ & 23 & 22 & 45 \\
\hline 4 & No tattoo & $\begin{array}{l}\text { Female } 1 \\
\text { Male } 1\end{array}$ & 25 & 23 & 48 \\
\hline 5 & No tattoo & $\begin{array}{l}\text { Female } 2 \\
\text { Male } 2\end{array}$ & 26 & 22 & 48 \\
\hline 6 & No tattoo & $\begin{array}{l}\text { Female } 3 \\
\text { Male } 3\end{array}$ & 25 & 23 & 48 \\
\hline
\end{tabular}




\section{Results}

Overall, stimulus condition (i.e. tattooed or non-tattooed) $\left(F_{10,265}=2.49 ; p<0.01\right)$ as well as the sex of the rater $\left(F_{10,265}=3.60 ; p<0.001\right)$ significantly influenced the perception of the stimulus figures. Moreover, there was also a significant interaction effect of tattoo ${ }^{*}$ sex of rater $\left(F_{10,265}=1.97 ; p<0.05\right)$. For stimulus condition, between-subject effects were found for female health $\left(F_{1,274}=4.60 ; p<0.05\right)$ and male dominance $\left(F_{1,274}=8.70 ; p<0.01\right)$, such that tattooed female figures were rated less healthy and tattooed male figures more dominant (Table 5.2).

Table 5.2 Mean and standard error of mean (S.E.M.) of all ratings as a function of the prevalence of a tattoo $(n=278)$.

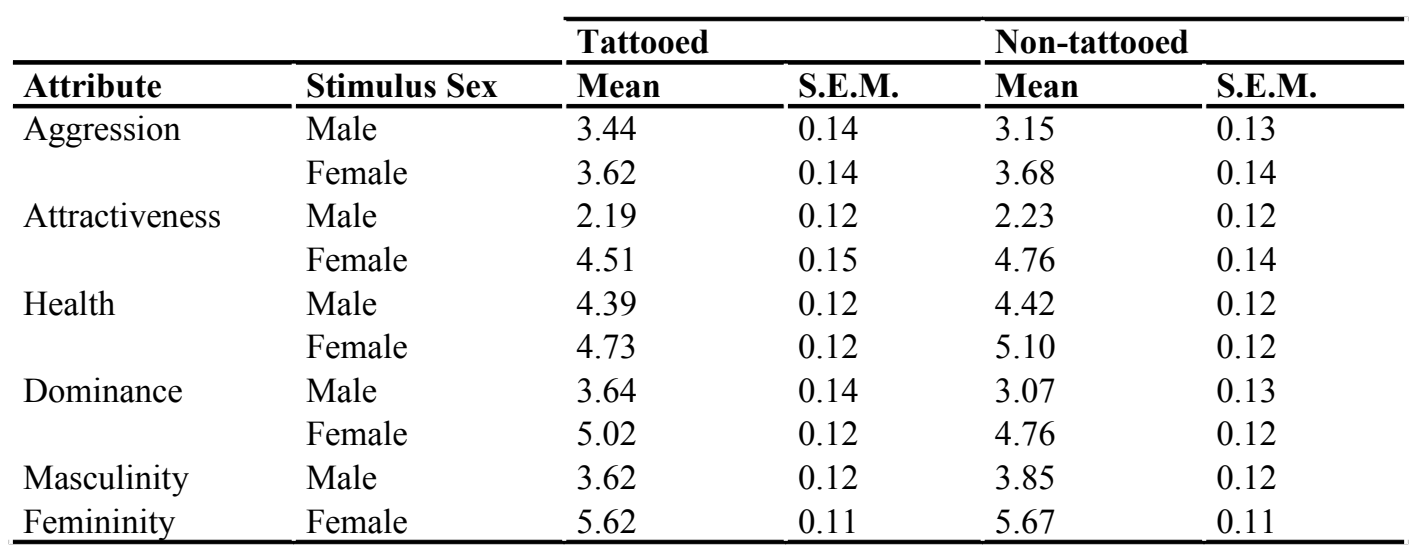

The sex of the rater significantly influenced attractiveness and dominance ratings (Table 5.3), such that men rated female figures as more attractive $\left(F_{1,274}=12.85 ; p<0.001\right)$ and women rated female figures more dominant $\left(F_{1,274}=11.00 ; p<0.001\right)$. Furthermore, male figures were rated more masculine by men (Table $5.3 ; F_{1,274}=6.57 ; p<0.05$ ). A significant interaction was only found for male health $\left(F_{1,274}=5.62 ; p<0.05\right)$ such that females considered male figures with tattoos healthier whereas men gave higher health ratings to male figures without tattoos. 
Table 5.3 Means and standard error of mean (S.E.M.) of all ratings as a function of the sex of the rater $(n=278)$.

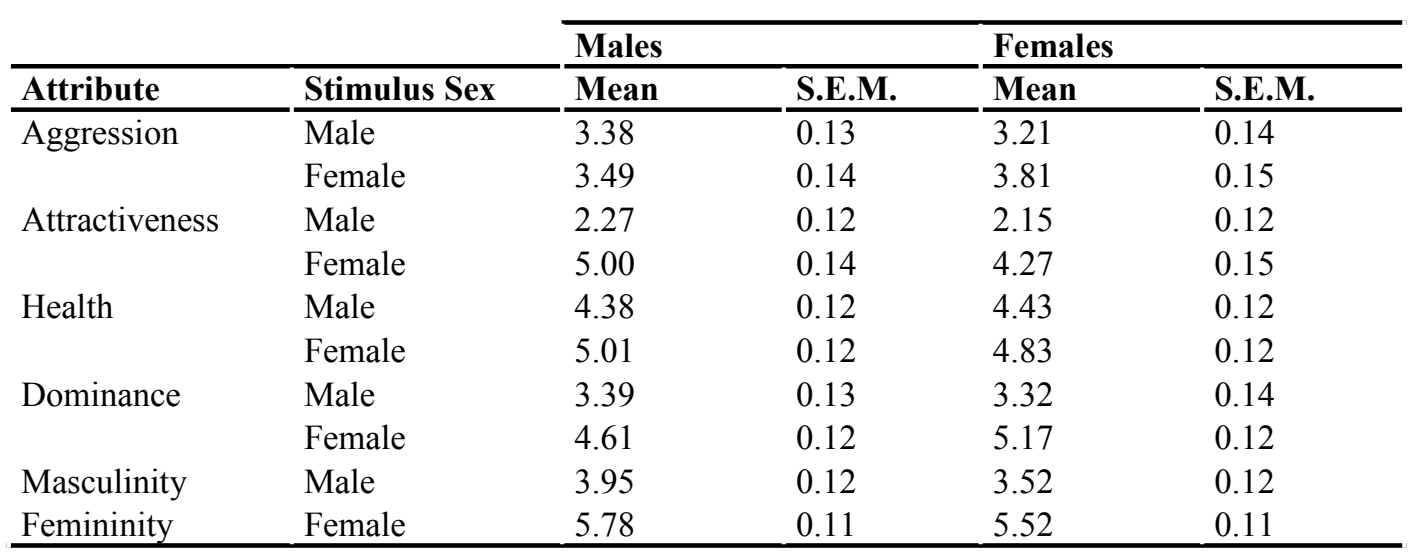

\section{Discussion}

The results failed to show that tattoos have a mate quality signaling function. We hypothesized that if tattoos act as quality signals in human mate choice, women should rate tattooed men as more attractive, more dominant, more masculine, healthier and less aggressive than non-tattooed men as it is known that women have some preference for men who maintain and express these attributes (Buss, 1989). Our study found that tattooed male figures were rated more dominant only, however not only by women but also by men. Women value increased dominance because dominant men may achieve a higher social status, earn more money and, thus, have more possibilities to invest in offspring (Buss \& Barnes, 1986; Sadalla, Kenrick \& Vershure, 1987). Therefore the acquisition of a tattoo may serve to display a man's increased dominance, serving to attract female partners and deter potential same-sex competitors.

However, women typically prefer dominant men during their fertile phase and for short-term relationships, while they favor sociable partners that are willing-to-invest outside the fertile window (Gangestad et al., 2002; Johnston et al., 2001; Penton-Voak et al., 1999) as well as for long-term relationships (Scheib, 2001). The fact that women's preference for a dominant partner changes cyclically and is influenced by the type of relationship sought, may perhaps explain the fact that the possession of a tattoo influenced dominance ratings but not the perception of attractiveness in male stimuli in the present study. Thus a role of tattoos as 
quality signals in mate choice remains speculative and further research could explore the role of the menstrual cycle and sexual strategy selection.

For tattooed female stimuli we predicted higher attractiveness, health and femininity ratings (Buss, 1989). However, these stimuli were rated as less rather than more healthy, contradicting our original prediction. There was no difference in the perception of other attributes investigated. Other studies have also failed to find differences in attractiveness ratings between tattooed and non-tattooed male and female models (Seiter \& Hatch, 2005), suggested that additional research is required in this area.

It is possible that the possession of a tattoo by the raters themselves could influence their perception of others with similar body modification. It has been suggested that mate choice in Western societies follow a 'like-attracts-like' decision rule rather than an 'oppositesattract' or a 'reproductive-potential-attract' rule. The 'like-attracts-like' decision rule states that partners are chosen based on a preference for similarity on several characteristics, one of which is physical appearance (Buston \& Emlen, 2003). Thus future research should examine the role of the possession of an own tattoo, which is likely to bear great influence on the perception of tattoos.

Ratings of tattooed stimuli might have been influenced by traditional stigmatizations. For example, tattoos have often been associated with dirtiness, poor hygiene and various health hazards - mainly infection of blood-borne diseases stemming from contaminated needles (Fisher, 2002; Irwin, 2001). Additionally, there is a long-lasting association with a deviant life style (Irwin, 2001), which may construct a masculine, and thus dominant identity (Messerschmidt, 1993). In the early twentieth century tattoos were only widespread within sub-cultures involving convicts, soldiers, sailors or bikers (Wohlrab, Fink \& Kappeler, 2005). Thus, tattooing may be viewed as a way in which to escape conventional constraints or engage with marginal groups, so that tattooed men might be suspected to be more oppositional, and more dominant and more aggressive - if not even criminal (Sanders, 1989; Vail, 1999).

It has also been shown that tattoos influence the perception of sociosexuality such that tattooed stimuli are perceived as having a higher number of sexual partners compared to nontattooed stimuli (Wohlrab, Fink, Kappeler \& Brewer, submitted). This was particularly true 
for male stimuli. Accordingly, Perusse (1993) found that men's social status predicted their number of sexual partners. Mazur, Halpern and Udry (1994) noticed that male adolescents with a dominant appearance reported their first copulation earlier in life than contemporaries who appeared less dominant. Thus the connection to such personality characteristics might rather explain the link between dominance ratings and tattoos. Therefore, a biological signaling function of modern tattoos might be strongly interweaved with psychological and culturally based aspects, and tattoos may rather have a social function in signaling identity than mate quality.

Surprisingly, female stimuli were generally rated higher on all attributes than male stimuli, which is especially stunning for aggression and dominance ratings. This might be an effect of the stimuli used in the experiment. Virtual figures were chosen in order to control for parameters that have been shown to influence attractiveness ratings. Those comprise bodily features like the waist-to-hip ratio (Singh, 1993), shoulder width (Horvath, 1981), facial features (e.g. Fink \& Penton-Voak, 2002) and other quality markers (for a summary see Grammer et al., 2003). However virtual figures have a more artificial appearance, which might alter the ratings. Additionally tattoos were chosen on common locations (Wohlrab et al., 2005), which comprise the lower back for women as well as the calf. Those positions cause some tattoos to be arranged symmetrically, but others asymmetrically e.g. if the tattoo is positioned on one calf. Symmetry is an important factor in attractiveness ratings, not only on natural features (Fink \& Penton-Voak, 2002) but also on artificial decorations (Cardenas \& Harris, 2005). Therefore the interpretation of the results should be viewed with caution.

In conclusion, our results did not provide sufficient evidence that tattoos generally enhance biological signals used in evaluating mate quality. Instead, we discuss the results in the light of a signaling function rather influenced by social factors. The relevance of social or biological factors in altering perception could not be clarified in this study and should be the subject of future research. One approach would be a comparison of biological traits between tattooed and non-tattooed individuals. If biological factors predominantly influence dominance ratings we would expect differences in testosterone levels between tattooed and non-tattooed individuals. Testosterone is related to dominance (Dabbs \& Dabbs, 2000). If no differences in testosterone levels occur, then culturally biased influences might predominate. 


\section{Chapter 6}

\section{Differences in personality attributions towards tattooed and non-tattooed virtual human characters}

Silke Wohlrab*, Bernhard Fink*, Peter M. Kappeler*o \& Gayle Brewer ${ }^{+}$

* Abteilung Soziobiologie / Anthropologie der Universität Göttingen, Deutschland

○ Abteilung Verhaltensökologie und Soziobiologie, Deutsches Primatenzentrum, Göttingen, Deutschland

${ }^{+}$Department of Psychology, University of Central Lancashire, Preston, United Kingdom 


\begin{abstract}
Individuals with body modifications, such as tattoos, have been shown to differ from non-modified individuals in sensation seeking personality characteristics and sociosexuality. This study examined possible differences in people's attributions of those traits towards virtual human characters varying in body modification. We used virtual characters in this study because, in contrast to natural stimuli, all other attributes that may affect rater's attributions can be experimentally fixed. 278 participants rated tattooed and non-tattooed bodies of avatars on aspects of sensation seeking and number of previous sexual partners. Tattooed stimuli were rated as more experience seeking, thrill and adventure seeking as well as more likely to have a high number of previous sexual partners and as less inhibited compared to non-tattooed stimuli, and this was particularly true for male stimuli. We conclude that people with body modifications, such as tattoos, are perceived differently compared to non-tattooed individuals in terms of sensation seeking personality characteristics and previous partner number, this being particularly true for men. We discuss our findings with reference to the evolutionary model of human sexual selection.
\end{abstract}




\section{Introduction}

Body modifications such as tattoos are wide spread, with a high prevalence across all age groups and social classes (DeMello, 2000; Wohlrab, Fink, \& Kappeler, 2005). The purpose of body ornaments has been addressed via a number of research fields. Consequently, several explanations for the potential signalling functions of these ornaments have been offered. The high prevalence of tattoos in various subcultures has been the focus for much of this research attention, with tattoos presumably signaling group affiliations and rebellion (Govenar, 2000; Pitts, 2003). Supporting evidence is provided by the relationship between the possession of a tattoo in adolescence and a number of high risk-taking behaviors (e.g. Carroll, Riffenburgh, Roberts, \& Myhre, 2002). Therefore, from an evolutionary perspective, tattoos may act as adaptive signals, which aid human sexual selection through the display of mate quality (Ludvico \& Kurland, 1995; Singh \& Bronstad, 1997).

Recent research has investigated the personality characteristics associated with body modification. For example, Nathanson, Paulhus and Williams (2006) found that openness to experience predicted the likelihood of having body modifications. Much of the research in this area (consistent with Carroll et al., 2002) has focused on the relationship between body modification and sensation seeking. Roberti, Storch and Bravata (2004) report a positive relationship between body modification and an individual's tendency to engage in new, intense and risky events, seeking unusual, miscellaneous and excessive sensations or experiences ("sensation seeking": Zuckerman, 1979).

A recent study by Wohlrab, Stahl, Rammsayer, and Kappeler (in press) found significant differences between body modified individuals and a non-modified control group with regards to both sensation seeking and sociosexual orientation. Body modified individuals displayed patterns of high sensation seeking and an unrestricted, i.e. more promiscuous sexual strategy. Sociosexual orientation depicts different mating strategies, ranging from restricted (a preference for long-term committed relationships) to unrestricted (a preference for shortterm relationships) (Simpson \& Gangestad, 1991). Wohlrab et al. (in press), therefore, concluded that body ornaments might provide important cues on personality. The present study intends to further test this hypothesis by investigating the attribution of traits to human characters with or without a tattoo. 
Research focusing on the perception of people with tattoos is typically scarce, although the presence of a tattoo is often associated with the possession of negative traits (Durkin \& Houghton, 2000). For example, Degelman and Price (2002) showed that women with tattoos were rated as less attractive, honest, generous and intelligent than women without tattoos. In addition, studies addressing attitudes towards tattooed individuals from employers (Bekhor, Bekhor, \& Gandrabur, 1995) and health care personnel (Stuppy, Armstrong, \& Casals-Ariet, 1998) showed that tattooed individuals evoke negative associations and thus may be treated differently in these environments. However, to our knowledge no study has examined the research beyond these general attributions and investigated whether observers also perceive the higher level of sensation seeking and a greater number of sexual partners found in tattooed individuals. The present study addressed this open question.

Given the differences in personality traits between tattooed and non-tattooed individuals we predicted that tattooed individuals would be attributed with a higher level of sensation seeking and a more unrestricted sociosexuality. We investigated people's attributions of personality characteristics towards tattooed and non-tattooed virtual human characters. Because individual attributes ranging from skin tone to clothing and hairstyle may affect ratings of personality traits, we opted to use virtual characters for this experiment because all of these variables can be experimentally held constant. Following our recent research (Wohlrab et al., in press), which suggested that sensation seeking and sociosexuality are related to body modification, we hypothesized that tattooed characters should receive (i) higher ratings of sensation seeking attributes, such as disinhibition, experience seeking and thrill and adventure seeking, (ii) lower ratings of boredom susceptibility, and (iii) should be perceived as more likely to have a high number of previous sexual partners than non-tattooed characters. Since personality and sociosexuality have been found to differ between the sexes, with men typically exhibiting higher values (Schmitt, 2005), sex of stimulus character and sex of the rater were considered.

The original SOI (Simpson \& Gangestad, 1991) represents a broad inventory containing a number of attitudinal and behavioural measures, many of which covary. This inventory has been widely used to ascertain individual's self reported adoption of a restricted or unrestricted sexual strategy. In this study, we investigate the attribution of specific traits or 
behaviours to a person, rather than the actual relationship between body modification and self-reported behaviour. Therefore participants were not required to complete the SOI for each target, and were instead asked to estimate the number of previous sexual partners for each male and female figure. This is consistent with previous research that required participants to attribute femininity (Singh \& Young, 1995) to an individual rather than completing a multi-item questionnaire for each figure.

\section{Methods}

\section{Participants}

Our sample comprised 145 men and 133 women aged 18 to 39 years (mean age = $23.84 \pm 2.97)$. All participants were opportunity sampled from the University of Goettingen, thus the sample mainly comprised undergraduate students.

\section{Stimuli}

Virtual human characters were created using the software Poser 6 (E-Frontier, Scotts Valley, USA). Six different characters, three males and three females, were created. Each character was constructed in two forms, once with and once without a tattoo. This resulted in a total of 12 stimuli. All stimuli wore standard bathing clothes and were presented in a slightly rotated frontal view (Figure 6.1). The advantage of these stimuli was that characters did not differ in other variables such as body shape or symmetry, which are known to affect attributions of physical appearance and personality (e.g. Singh, 1993; Fink et al., 2006). Based on the results of previous research (Wohlrab, Fink \& Kappeler, 2005; Wohlrab et al., in press), tattoos were placed on commonly used body areas such as upper arm or calf. The most common category of tattoo design 'tribals' was chosen (Wohlrab et al., in press), which encompass bold, black, silhouette style designs and are characterized by symmetrically arranged rolling lines. 

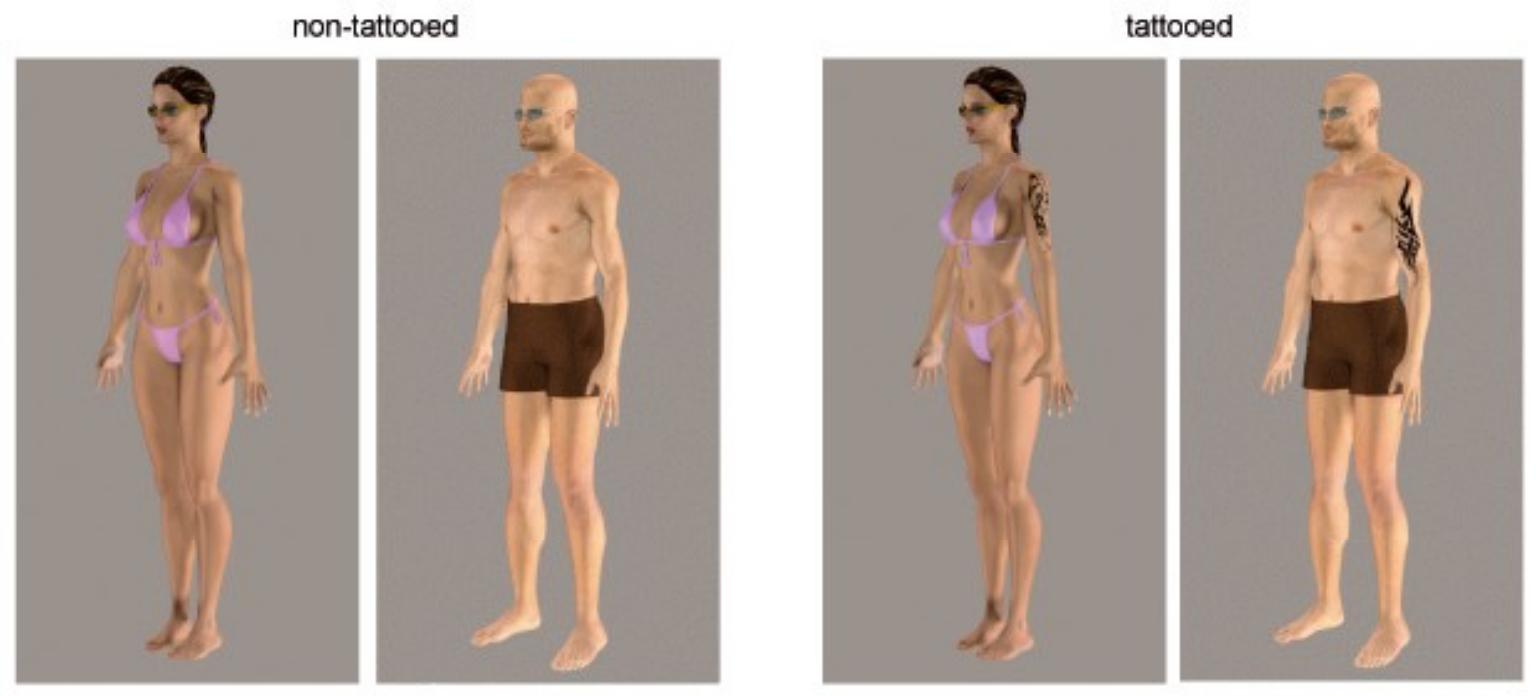

Figure 6.1 One male and one female stimulus, each with and without tattoo.

\section{Procedure}

Experiments were designed using Media Lab Research Software (Empirisoft Inc., New York, USA). Each condition comprised one male and one female stimulus, presented in the same format, i.e. both figures were either tattooed or not tattooed. Thus, each participant rated two figures, one male and one female character, which were either both tattooed or both not tattooed. Stimuli were presented on a 17-inch flat screen (Iiyama ProLite E 4815) with a resolution of $1280 \times 1024$ pixels in a random order. Participants rated each figure on a number of attributes based on the four items of the Sensation Seeking Scale (SSS-V; Zuckerman, 1979) and one item of the Sociosexual Orientation Inventory (Simpson \& Gangestad, 1991). Thus, stimuli were rated on a 7-point Likert scale (from $1=$ 'not' to $7=$ 'very') for boredom susceptibility, (dis)inhibition, experience seeking, thrill and adventure seeking and number of different sexual partners in the past twelve months (Likert scale ranging from ' 0 ' to ' 5 ' in single steps plus a last category called 'more than 5 ' different sexual partners). For translation of the items of the Sensation Seeking Scale we referred to Beauducel, Strobel and Brocke (2003). Due to language differences such that disinhibition is rarely used in the German language, the factor 'disinhibition' was inversely coded, thus resembles and is further on referred to as 'inhibition'. 


\section{Results}

Inter-rater reliability was tested using Cronbach's Alpha measure of internal consistency. Alphas ranged from 0.85 (thrill and adventure seeking) to 0.96 (inhibition) and were thus regarded considerably high. Group comparisons were conducted using repeated measures ANOVA with a $2 \times 2 \times 2$ factorial design, with sex of rater (male, female) and condition of stimuli (tattooed, not tattooed) as between subject factors and sex of stimulus (male, female) as within subject variable.

Mauchly's test for sphericity showed that the assumption of homogeneity of variances was not violated. The overall model revealed main effects for stimulus condition $\left(\mathrm{F}_{5,270}=\right.$ $\left.6.59 ; \mathrm{p}<0.001 ; \eta^{2}=0.109\right)$ and sex of stimulus $\left(\mathrm{F}_{5,270}=65.49 ; \mathrm{p}<0.001 ; \eta^{2}=0.548\right)$. Stimulus condition influenced ratings of inhibition $\left(\mathrm{F}_{1,274}=7.45 ; \mathrm{p}<0.01 ; \eta^{2}=0.026\right)$, experience seeking $\left(\mathrm{F}_{1,274}=29.20 ; \mathrm{p}<0.001 ; \eta^{2}=0.096\right)$, thrill and adventure seeking $\left(\mathrm{F}_{1,274}=\right.$ $\left.11.21 ; p<0.001 ; \eta^{2}=0.039\right)$, and the number of sexual partners $\left(F_{1,274}=6.30 ; p<0.05 ; \eta^{2}=\right.$ 0.022). Tattooed stimuli were rated as less inhibited, but as higher in their drive for experience seeking as well as thrill and adventure seeking, and also having more sexual partners. The sex of the rater influenced ratings on the number of sexual partners only $\left(\mathrm{F}_{1,274}=\right.$ 5.19; $\mathrm{p}<0.05 ; \eta^{2}=0.019$ ), with women attributing a higher number of sexual partners to the target person than male raters (Table 6.1). A significant interaction between sex of rater and stimulus condition emerged for boredom susceptibility such that men rated non-tattooed stimuli lower but tattooed stimuli higher on boredom susceptibility compared to women $\left(\mathrm{F}_{1,274}\right.$ $\left.=5.11 ; \mathrm{p}<0.05 ; \eta^{2}=0.018\right)$.

Significant effects of sex of stimulus were found for all ratings, boredom susceptibility $\left(F_{1,274}=77.98 ; p<0.001 ; \eta^{2}=0.222\right)$, inhibition $\left(F_{1,274}=186.66 ; p<0.001 ; \eta^{2}=0.405\right)$, experience seeking $\left(F_{1,274}=32.66 ; p<0.001 ; \eta^{2}=0.107\right)$, thrill and adventure seeking $\left(F_{1,274}\right.$ $\left.=59.10 ; \mathrm{p}<0.001 ; \eta^{2}=0.177\right)$, as well as the number of sexual partners $\left(\mathrm{F}_{1,274}=211.51 ; \mathrm{p}<\right.$ $0.001 ; \eta^{2}=0.436$ ), where male figures were rated higher in all attributions but inhibition (Table 6.1). Significant interactions between sex of stimulus and sex of rater emerged for the variables inhibition $\left(F_{1,274}=9.71 ; p<0.01 ; \eta^{2}=0.034\right)$ and thrill and adventure seeking $\left(F_{1,274}\right.$ $\left.=11.06 ; \mathrm{p}<0.001 ; \eta^{2}=0.039\right)$. Men rated male stimuli less inhibited and higher in thrill 
and adventure seeking than women but rated female stimuli more inhibited and lower in thrill and adventure seeking compared to women.

Table 6.1 Mean and standard error of mean (S.E.M.) of all ratings as a function of the prevalence of a tattoo in the stimulus (males $n=145$; female $n=133$ ).

\begin{tabular}{|c|c|c|c|c|c|c|}
\hline \multirow{2}{*}{ Sex Rater } & \multirow{2}{*}{ Attribute } & \multirow{2}{*}{ Sex Stimulus } & \multicolumn{2}{|c|}{ Tattooed } & \multicolumn{2}{|c|}{ Non-tattooed } \\
\hline & & & Mean & S.E.M. & Mean & S.E.M. \\
\hline \multirow[t]{10}{*}{ Female } & \multirow[t]{2}{*}{ Boredom susceptibility } & Male & 5.03 & 0.18 & 5.40 & 0.17 \\
\hline & & Female & 3.99 & 0.20 & 3.97 & 0.19 \\
\hline & \multirow[t]{2}{*}{ Inhibition } & Male & 1.85 & 0.17 & 2.24 & 0.16 \\
\hline & & Female & 3.77 & 0.20 & 4.29 & 0.20 \\
\hline & \multirow[t]{2}{*}{ Experience Seeking } & Male & 5.23 & 0.19 & 4.84 & 0.18 \\
\hline & & Female & 4.54 & 0.17 & 3.77 & 0.17 \\
\hline & \multirow[t]{2}{*}{ Thrill and Adventure Seeking } & Male & 5.32 & 0.18 & 4.96 & 0.17 \\
\hline & & Female & 4.12 & 0.19 & 3.50 & 0.19 \\
\hline & \multirow[t]{2}{*}{ Number of Sexual Partners } & Male & 5.39 & 0.19 & 5.03 & 0.18 \\
\hline & & Female & 3.97 & 0.21 & 3.04 & 0.21 \\
\hline \multirow[t]{10}{*}{ Male } & \multirow[t]{2}{*}{ Boredom susceptibility } & Male & 5.01 & 0.17 & 4.87 & 0.16 \\
\hline & & Female & 4.29 & 0.19 & 3.62 & 0.18 \\
\hline & \multirow[t]{2}{*}{ Inhibition } & Male & 2.45 & 0.16 & 2.64 & 0.15 \\
\hline & & Female & 3.62 & 0.20 & 3.97 & 0.19 \\
\hline & \multirow[t]{2}{*}{ Experience Seeking } & Male & 5.00 & 0.19 & 4.20 & 0.17 \\
\hline & & Female & 4.52 & 0.17 & 3.75 & 0.16 \\
\hline & \multirow[t]{2}{*}{ Thrill and Adventure Seeking } & Male & 4.73 & 0.17 & 4.46 & 0.16 \\
\hline & & Female & 4.30 & 0.18 & 3.83 & 0.18 \\
\hline & \multirow[t]{2}{*}{ Number of Sexual Partners } & Male & 4.84 & 0.18 & 4.83 & 0.17 \\
\hline & & Female & 3.30 & 0.20 & 3.05 & 0.19 \\
\hline
\end{tabular}

\section{Discussion}

Our results revealed that tattooed virtual characters were perceived differently compared to non-tattooed figures such that tattooed characters were considered to be more experience seeking, more thrill and adventure seeking, more susceptible to boredom, obtain a greater number of sexual partners and be less inhibited compared to non-tattooed characters.

Previous studies have found that people with tattoos report higher scores levels of sensation seeking (Roberti et al., 2004; Wohlrab et al., in press). Specifically, in the inhibition and experience seeking subscales, participants were more open to new experiences than nontattooed controls (Nathanson et al., 2006). In addition, tattooed individuals are more likely to follow an unrestricted sexual strategy, demonstrating a preference for a greater number of partners and short-term relationships with a relatively low degree of commitment (Wohlrab et 
al., in press). The current study suggests that observers may be aware of the relationship between body modification and personality or sexual behavior. The traits reported to a greater degree by tattooed individuals were also attributed to tattooed characters by naïve observers. Therefore tattoos may serve to signal aspects of personality during social interaction.

A strong influence of sex was found, with male characters typically being rated as more sensation seeking than female characters. The sex of the rater also influenced ratings. Women typically attributed a greater number of sexual partners to each character displayed. Men perceived characters to be more thrill and adventure seeking and less inhibited than women. These sex differences could illustrate the signaling function of tattoos in human sexual selection as has been previously suggested (Ludvico \& Kurland, 1995; Singh \& Bronstad, 1997; Wohlrab et al., in press). However, virtually created tattooed and nontattooed human characters were employed and so caution should be exercised when extrapolating to 'real' people.

Sensation seeking and sociosexual orientation are related to testosterone (T), which also correlates with a number of physical and behavioral characteristics that also influence mating decisions (Grammer, Fink, Møller, Thornhill, 2003; Hines, Brook, Conway, 2004; Hines, 2006). Daitzmann and Zuckerman (1980) reported that higher scores on sensation seeking measures of disinhibition were associated with higher $\mathrm{T}$ levels in male college students (see also Daitzman, Zuckerman, Sammelwitz \& Ganjam, 1978). One plausible explanation for the finding is that young males (with greater $\mathrm{T}$ levels) are more likely to engage in risky confrontations. This is consistent with Wilson and Daly's assertion (1985) that dangerous competition can result in a rise in social status, which may increase a woman's interest in a potential partner (Buss, 1989). Our data indicate that people associate body modifications with such risk taking personality characteristics, particularly in men, and consider them also sexually more unrestricted. It is therefore likely that tattoos influence human mating decisions.

The explicit signaling of basic personal values and preferences may help individuals to define and identify a group of potential partners more easily and increase the likelihood of reproductive success (Graziano, Jensen-Campbell, Shebilske \& Lundgren, 1993). Previous research suggests that positive assortment in sensation seeking may predict relationship 
functioning (e.g. Farley \& Davis, 1977; Ficher, Zuckerman \& Steinberg 1988). This may be due to the relationship between sensation seeking and a number of other variables that affect everyday life, for example music preference (Arnett, 1991; Litle \& Zuckerman, 1986), program choice (Schierman \& Rowland, 1985; Zuckerman \& Litle, 1986) and the preference for a particular sport (Zuckerman, 1983). These variables may be particularly important for male reproductive success, because women's preference for a particular mate is influenced to a greater degree by factors such as personality and social status (Townsend \& Wasserman, 1997).

Men typically exhibit higher sensation seeking tendencies than women (Zuckerman, Eysenck \& Eysenck, 1978; Ball, Farnhill \& Wangeman, 1984). Therefore, sensation seeking may be more predictive of male than female behavior. In addition to the evolutionary explanation, it is important to recognize that body ornaments may also signal involvement in a particular subculture and nonconformist behavioral tendencies. It is this involvement that may result in greater attributions of sensation seeking and promiscuity (Pitts, 2003).

In conclusion, our results suggest that body modifications such as tattoos affect the attribution of risk taking personality traits and the number of sexual partners obtained. These findings were particularly salient for male characters. As these personality characteristics have a number of consequences for human mating, we suggest that tattoos influence human mating decisions. However, future studies should investigate the preference for a body modified versus non-modified partner to determine whether this is an evolutionary biased or socioculturally motivated effect. 


\section{Conclusions}

In conclusion, the results of the studies presented in this thesis provide several hints that tattoos might act in human sexual selection, specifically in mate choice. First, tattoos draw attention and alter the perception of observers. This alteration varies between the sexes, such that men generally paid more attention to tattoos, specifically to tattooed women (Wohlrab, Fink, Pyritz, Rahlfs, Kappeler, 2007). Furthermore, the most frequently selfreported motivation for the acquisition of tattoos was beautification (Wohlrab, Stahl \& Kappeler, 2007). Also in other cultures body modifications possess aesthetic value (Wohlrab, Fink \& Kappeler, 2005). However, I found no support for the hypothesis that tattoos signal mate quality (Wohlrab, Fink, Kappeler \& Brewer, submitted,b). Instead, tattoos appear to signal personality because body modified individuals exhibited higher scores in sensation seeking traits and sociosexuality (Wohlrab, Stahl, Rammsayer \& Kappeler, 2007). These differences were not only self-reported but also perceived by others (Wohlrab, Fink, Kappeler \& Brewer, submitted,a), so that tattoos might act as signals for sensation seeking and sociosexuality.

Sensation seeking and sociosexuality are functionally related to human mating behavior. Sociosexuality affects a particular mating strategy as well as the attitude towards sexual behavior. It ranges from a monogamous, long-term to a more promiscuous, short-term strategy with frequently varying sexual partners (Gangestad \& Simpson, 2000; Simpson \& Gangestad, 1991). Sensation seeking is also related to sexual behavior; especially the subscale disinhibition contains traits regarding a love style characterized by low commitment and high autonomy of the partners (Bancroft, Janssen, Carnes, Goodrich, Strong \& Long 2004; Richardson, Medvin \& Hammock 1988) but also embraces other socially relevant traits. Sensation seeking resembles certain attitudes and personal values in everyday life such as preferences for types of sport (Zuckerman, 1983), music (Litle \& Zuckerman, 1986), and media program (Brown, Ruder, Ruder, \& Young, 1974; Schierman \& Rowland, 1985; Zuckerman \& Litle, 1986). A match in the amount of sensation seeking between partners is an important predictor for functioning relationships (e.g. Ficher, Zuckerman \& Steinberg, 1988), thus constituting a significant aspect in mate choice. Specifically tattooed men were perceived 
as higher sensation seekers, indicating that primarily women might use this information in choosing a partner. Generally, women rather emphasize social attributes and personality when evaluating potential mates, while men rather concentrate on physical attributes (Buss, 1989).

To sum up it appears that biological and psychological factors are strongly interweaved when considering the signaling value of tattoos. It seems that tattoos act as signals in mate choice by signaling personality rather than quality. 


\section{Summary}

In recent years, body modification such as tattoos and body piercings became fashionable again and increased considerably in prevalence. Previously, body modification has been suggested to act as a handicap signal in native cultures. The focus of my studies was to investigate the potential function of body modification, specifically of tattoos, in human sexual selection. In two literature reviews I accumulated evidence that body modification might possess a signaling value in mate choice. First I compared functional aspects between cultures and across time, which point towards a function in mate choice. Then I considered motivational aspects of getting body-modified and found that the most frequently mentioned motivations concern an increase in attractiveness, which is a primary criteria in mate choice. In an eyetracking study I found that tattooed bodies also attract more attention than plain, scarred or accessorized bodies, so that they actually act as signals and seem to carry information. However, when testing the potential biological signaling value by examining the perception of tattoos concerning mate choice criteria, I found that tattooed bodies were neither rated more attractive nor healthier, which contradicted the hypothesis of tattoos as quality signals in mate choice. A questionnaire survey revealed differences of body-modified individuals in certain personality characteristics such as Sensation Seeking and Sociosexuality, in which body-modified scored higher than non-modified individuals. These differences in personality were also perceived by others because tattooed bodies were rated higher on Sensation Seeking and Sociosexuality. Sensation Seeking and Sociosexuality are traits relevant in mate choice. Therefore I concluded that tattoos do act as signals in mate choice but rather in signaling personality than quality. 


\section{ZUSAMMENFASSUNG}

In den letzten Jahren sind Körpermodifizierungen wie Tätowierungen und Piercings nach langer Zeit wieder in Mode gekommen und werden seitdem immer häufiger. Bei Kulturvölkern wurde gezeigt, dass Körpermodifizierungen die Funktion eines HandicapSignals haben können. Der Schwerpunkt meiner Studien lag darauf, die potentielle Signalfunktion von Körpermodifizierungen, insbesondere von Tattoos, in der sexuellen Selektion des Menschen der modernen westlichen Welt genauer zu untersuchen. In einem kulturübergreifenden Vergleich funktionaler Aspekte fand ich Hinweise auf eine potentielle Funktion von Körpermodifizierungen in der sexuellen Selektion. Des weiteren bestätigen Motivationen für den Erwerb von Tätowierungen und Piercings eine solche Funktion, da die Verschönerung des eigenen Körpers am häufigsten genannt wird, und Schönheit ein wesentliches Kriterium in der Partnerwahl ist. In einer Eyetracking-Studie fand ich heraus, dass tätowierte Körper mehr Aufmerksamkeit erregen als Körper mit Narben, Modeaccessoires oder ohne Verzierung. Daher scheinen Tattoos als Signale zu wirken, die gewisse Informationen beinhalten. Allerdings konnte die potentielle biologische Funktion von Tattoos als Qualitäts- bzw. Handicapsignal in einer Wahrnehmungsstudie, in welcher gängige Partnerwahlkriterien bewertet wurden, nicht bestätigt werden, da tätowierte Körper weder attraktiver noch gesünder bewertet wurden. Eine Fragebogenerhebung ergab, dass körpermodifizierte Individuen in den Persönlichkeitsmerkmalen „Sensation Seeking“ und „Soziosexualität“ höhere Werte aufwiesen. Ein höherer Drang zum Sensation Seeking und eine weniger restriktiven Soziosexualität wurde tätowierten Körpern auch in einer Bewertungsstudie zugeschrieben. Beide Persönlichkeitsmerkmale stellen wiederum wichtige Aspekte in der Partnerwahl dar. Daher scheinen Tattoos zwar als Signale in der Partnerwahl zu fungieren, allerdings eher als Persönlichkeits- denn als Qualitätssignale. 


\section{Acknowledgements}

I am grateful to Peter Kappeler, who offered me a position to work on this very interesting topic and supported me with helpful theoretical considerations and fincancial support throughout the course of my work.

The Deutsche Forschungsgemeinschaft contributed financial support.

I am indebted to Jutta Stahl for her efforts concerning the research as well as mental support in various ways.

Many thanks to Henning Gibbons for his support as a referee of this dissertation.

Bernhard Fink greatly supported the experiments by offering his expertise in human behavioral research as well as by contributing constructive theoretical comments.

Also many thanks to Gayle Brewer for her helpful contributions in the rating studies.

And finally many thanks to all the participants of the experiments, especially to all tattooees and piercees who sacrifized their time to fil in my quite extensive questionnaire. 


\section{REFERENCES}

Althoff, R.R., \& Cohen, D. (1999). Eye-movement-based memory effect: a reprocessing effect in face perception. Journal of Experimental Psychology: Learning, Memory and Cognition, 25, 997-1010.

Amundsen, T., \& Forsgren, E. (2001). Male mate choice selects for female coloration in a fish. Proceedings of the National Academy of Sciences of the United States of America, 98, 13155-13160.

Andersson, M. (1994). Sexual selection. Princeton, NJ: Princeton University Press.

Armstrong, M.L. (1991). Career-oriented women with tattoos. Image: Journal of Nursing Scholarship, 23, 215-220.

Armstrong, M.L. (1995). Adolescent tattoos: Educating vs. pontificating. Pediatric Nursing, 21, 561-564.

Armstrong, M.L., Caliendo, C., \& Roberts, A.E. (2006). Genital piercings: what is known and what people with genital piercings tell us. Urologic Nursing, 26, 173-180.

Armstrong, M.L., Ekmark, E., \& Brooks, B. (1995). Body piercing: promoting informed decision making. Journal of School Nursing, 11, 20-25.

Armstrong, M.L. \& McConnell, C. (1994). Tattooing in adolescents, more common than you think: the phenomenon and risks. Journal of School Nursing, 10, 22-29.

Armstrong, M.L., Murphy, K., Sallee, A., \& Watson, M.G. (2000). Tattooed army soldiers: examining the incidence behavior, and risk. Military Medicine, 165, 135-141.

Armstrong, M.L., Owen, D.C., Roberts, A.E., \& Koch, J.R. (2002). College students and tattoos. Influence of image, identity, family and friends. Journal of Psychosocial Nursing and Mental Health Services, 40, 20-29.

Armstrong, M.L., \& Pace Murphy, K. (1997). Tattooing: Another adolescent risk behavior warranting health education. Applied Nursing Research, 10, 181-189.

Armstrong, M.L, Roberts, A.E., Koch, J.R., Saunders, J.C., \& Owen, D.C. (forthcoming). Investigating the removal of body piercings. Clinical Nursing Research.

Armstrong, M.L., Roberts, A.E., Owen, D.C., Koch, J.R. (2004). Contemporary college students and body piercing. Journal of Adolescent Health, 35, 58-61.

Armstrong, M.L., Stuppy, D.J., Gabriel, D.C., \& Anderson, R.R. (1996). Motivation for tattoo removal. Archives of Dermatology, 132, 412-416.

Arnett, J.J. (1991). Heavy metal music and reckless behavior among adolescents. Journal of Youth and Adolescence, 20, 573-592.

Atkinson, M. (2002). Pretty in ink: conformity, resistance, and negotiation in women's tattooing. Sex Roles, 47, 219-235.

Atkinson, M. (2003). Tattooed: the sociogenesis of a body art. Toronto: University of Toronto Press.

Atkinson, M. (2004). Tattooing and civilizing processes: body modification as self-control. Canadian Review of Sociology \& Anthropology, 41, 125-146.

Atkinson, M. \& Young, K. (2001). Flesh journeys: neo primitives and the contemporary rediscovery of radical body modification. Deviant Behavior, 22, 117-146.

Balsamo, A. (1996). Technologies of the gendered body: reading cyborg women. Durham, NC: Duke University Press.

Ball, I.L., Farnhill, D., \& Wangeman, J.F. (1984). Sex and age differences in sensation seeking: some national comparisons. British Journal of Psychology, 75, 257-265.

Bancroft, J., Janssen, E., Carnes, L., Goodrich, D., Strong, D., \& Long, J.S. (2004). Sexual activity and risk taking in young heterosexual men: the relevance of sexual arousability, mood, and sensation seeking. The Journal of Sex Research, 41, 181-192.

Bateman, A. J. (1948). "Intra-sexual selection in Drosophila." Heredity, 2, 349-368. 
Bazan, L.E., Harris, L., \& Lorentzen, L.A. (2002). Migrant gangs, religion and tattoo removal. Peace Review, 14, 379-383.

Beauducel, A., Strobel, A., \& Brocke, B. (2003). Psychometrische Eigenschaften und Normen einer deutschsprachigen Fassung der Sensation Seeking-Skalen, Form V. [Psychometric traits and norms of a German adaptation of the Sensation Seeking Scale, version V]. Diagnostica, 49, 61-72.

Bekhor, P.S., Bekhor, L., \& Gandrabur, M. (1995). Employer attitudes toward persons with visible tattoos. Australasian Journal of Dermatology, 36, 75-77.

Bellwood, P. (1989). The colonization of the Pacific: some current hypotheses. In A.V.S. Hill $\&$ Serjeantson, S.W. (Eds.), The Colonization of the Pacific - A genetic trail (pp. 1-59). Oxford: Clarendon Press.

Bem, S.L. (1974). The measurement of psychological androgyny. Journal of Consulting and Clinical Psychology, 42, 155-162.

Benson, S. (2000). Inscriptions of the self: reflections on tattooing and piercing in contemporary Euro-America. In J.Caplan (Ed.). Written on the body: the tattoo in European and American history. (pp. 234-254). Princeton, NJ. Princeton University Press.

Berns, M.C. (1988). Ga'anda scarification: a model for art and identity. In A. Rubin (Ed.), Marks of Civilization. (pp. 57-76). Los Angeles: Museum of Cultural History.

Bianchi, R. S. (1988). Tattoo in Ancient Egypt. In A. Rubin (Ed.), Marks of Civilization. (pp. 21-28). Los Angeles: Museum of Cultural History.

Birmingham, L., Mason, D., \& Grubin, D. (1999). The psychiatric implications of visible tattoos in an adult male prison population. The Journal of Forensic Psychiatry, 10, 687-695.

Blanchard, M. (1994). Post-bourgeois tattoo: reflections on skin writing in late capitalist societies. In L. Taylor (Ed.). Visualizing theory: selected essays from V.A.R., 1990-1994. New York: Routledge.

Blount, J.D., Metcalfe, N.B., Birkhead, T.R., \& Surai, P.F. (2003). Carotenoid modulation of immune function and sexual attractiveness in zebra finches. Science, 300, 125-127.

Brähler, E., Strauß, B., Hessel, A., \& Schumacher, J. (2000). Normierung des Fragebogens zur Beurteilung des eigenen Körpers (FBeK) an einer repräsentativen Bevölkerungsstichprobe. [Standardization of the Questionnaire on the Perception of one's Own Body with a representative sample]. Diagnostica, 46, 156-164.

Brown, L.T., Ruder, V.G., Ruder, J.H., \& Young, S.D. (1974). Stimulation seeking and the Change Seeker Index. Journal of Consulting and Clinical Psychology, 42, 311.

Buss D.M. (1989). Sex differences in human mate preferences: evolutionary hypotheses tested in 37 cultures. Behavioral and Brain Sciences, 12, 1-49.

Buss, D.M., \& Barnes, M. (1986). Preferences in human mate selection. Journal of Personality and Social Psychology, 50, 559-570.

Buss, D.M., \& Schmitt, D.P. (1993). Sexual strategies theory: An evolutionary perspective on human mating. Psychological Review, 100, 204-232.

Buston, P.M., \& Emlen, S.T. (2003). Cognitive processes underlying human mate choice: The relationship between self-perception and mate preference in Western society. Proceedings of the National Academy of Sciences, 100, 8805-8810.

Caliendo, C., Armstrong, M.L., Roberts, A.E. (2005). Self-reported characteristics of women and men with intimate body piercings. Journal of Advanced Nursing, 49, 474-484.

Camphausen, R. (1997). Return of the tribal: a celebration of body adornment. Rochester, VT: Park Street Press.

Caplan, J. (2000). Written on the body: the tattoo in European and American history. Princeton, NJ: Princeton University Press. 
Cardenas, R.A., \& Harris, L.J. (2005). Symmetrical decorations enhace the attractiveness of faces and abstract designs. Evolution and Human Behavior, 27, 1-18.

Carroll, L., \& Anderson, R. (2002). Body piercing, tattooing, self-esteem, and body investment in adolescent girls. Adolescence, 37, 627-637.

Carroll, S.T., Riffenburgh, R.H., Roberts, T.A., \& Myhre, E.B. (2002). Tattoos and body piercings as indicators of adolescent risk-taking behaviors. Pediatrics, 109, 1021-1027.

Ceniceros, S. (1998). Tattooing, body piercing, and Russian roulette. Journal of Nervous and Mental Disease, 186, 503.

Cimo, J.D. (2003). A psychological use of tattoos: transitional phenomena and selfobject functions in lesbigaytrans persons. (unpublished) $\mathrm{PhD}$ thesis, Pacifica Graduate Institute, USA. Dissertation Abstracts International: Section B: The Sciences \& Engineering, 63, 6120.

Claes, L., Vanderdeycken, W., \& Vertommen, H. (2005). Self-care versus self-harm: piercing, tattooing and self-injuring in eating disorders. European Eating Disorders Review, 13, 11-18.

Clutton-Brock, T. (2004). What is sexual selection? In P.M. Kappeler \& C.P. Van Schaik (Eds.). Sexual Selection in primates: new and comparative perspectives. (pp. 24-36). Cambridge, Cambridge University Press.

Coe, K., Harmon, M.P., Verner, B., \& Tonn, A. (1993). Tattoos and male alliances. Human Nature, 4, 199-204.

Costa, P.T., \& McCrae, R.R. (1985). The NEO Personality Inventory manual. Odessa, Fl: Psychological Assessment Resources.

Craik, J. (1994). The face of fashion: cultural studies in fashion. London: Routledge.

Dabbs, J.M., \& Dabbs, M.G. (2000). Heroes, rogues, and lovers - Testosterone and behavior. McGraw Hill.

Daitzman, R., \& Zuckerman, M. (1980). Disinhibitory sensation seeking, personality and gonadal hormones. Personality and Individual Differences, 1, 103-110.

Daitzman, R., Zuckerman, M., Sammelwitz, P., \& Ganjam, V. (1978). Sensation seeking and gonadal hormones. Journal of Biosocial Science, 10, 401-408.

Dale, J., Lank, D.B., \& Reeve, H.K. (2001). Signaling individual quality versus identity: a model and case studies with ruffs, queleas and house finches. The American Naturalist, 158, 75-86.

Darwin, C. (1871). The descent of man and selection in relation to sex. London: Murray.

Degelman, D., \& Price, N.D. (2002). Tattoos and ratings of personal characteristics. Psychological Reports, 90, 507-514.

Delazar, M.E. (2005). The relationship between self-esteem, objectified body consciousness, personality traits and body modification: An exploratory study. (unpublished) $\mathrm{PhD}$ thesis, Indiana University Pennsylvania, USA. Dissertation Abstracts International: Section B: The Sciences and Engineering, 65, 5395.

DeMello, M. (1993). The convict body: tattooing among male American prisoners. Anthropology Today, 9, 10-13.

DeMello, M. (1995). "Not just for bikers anymore": popular representations of American tattooing. Journal of Popular Culture, 29, 37-52.

DeMello, M. (2000). Bodies of inscription: a cultural history of the modern tattoo community. Durham: Duke University Press.

Deubel, H. \& Schneider, W.X. (1996). Saccade target selection and object recognition: evidence for a common attentional mechanism. Vision Research, 36, 1827-1837.

Doll, D.C. (1988). Tattooing in prison and HIV infection. The Lancet, 1, 66-67. 
Doll, T.J., Worther, S., \& Schmieder, D.E. (1993). Simulation of human visual search in cluttered backgrounds. Proceedings of the Human Factors and Ergonomics Society, $37^{\text {Th }}$ Annual Meeting. (pp. 1310-1314). Santa Monica, CA.

Dorfer, L., \& Moser, M. (1998). 5200-year-old acupuncture in central Europe? Science, 282, 239.

Dorfer, L., Moser, M., Bahr, F., Spindler, K., Egarter-Vigl, E., Guillén, S., Dohr, G., \& Kenner, T. (1999). A medical report from the stone age? The Lancet, 354, 1023-1025.

Drews, D.R., Allison, C.K., \& Probst, J.R. (2002). Behavioral and self-concept differences in tattooed and nontattooed college students. Psychological Reports, 86, 475-481.

Drickamer, L. Gowaty, P. and Holmes, C. (2000). Free female mate choice in house mice affects reproductive success and offspring viability and performance. Animal Behaviour, 59, 371-378.

Duchowski, A.T. (2003). Eye tracking methodology: theory and practice. London: Springer Verlag.

Dunn, P.O., Whittingham, L.A., \& Pitcher, T.E. (2001). Mating systems, sperm competition, and the evolution of sexual dimorphism in birds. Evolution, 55, 161-175.

Durkin, K., \& Houghton, S. (2000). Children's and adolescents' stereotypes of tattooed people as delinquent. Legal and Criminological Psychology, 5, 153-164.

Eibl-Eibesfeldt, I. (1997). Die Biologie des menschlichen Verhaltens. Grundriß der Humanethologie. [Biology of human behavior. Basics of human ethology]. (4. Auflage), Piper Verlag München.

Faris, J. (1988). Significance of differences in the male and female personal art of the southeast Nuba. In A. Rubin (Ed.), Marks of Civilization. Los Angeles: Museum of Cultural History.

Farley, F.H., \& Davis, S.A. (1977). Arousal, personality, and assortative mating in marriage. Journal of Sex and Marital Therapy, 3, 122-127.

Featherstone, M. (1991). The body in consumer culture. In M. Featherstone, M. Hepworth \& B. Turner (Eds.). The body: social process and cultural theory. London: Sage.

Featherstone, M. (1999). Body modification: an introduction. Body \& Society, 5, 1-13.

Featherstone, M. (2000). Body modification. London: Sage.

Ferguson, H. (1999). Body Piercing. British Medical Journal, 319, 1627-1629.

Ferreira, F., \& Clifton, C. (1986). The independence of syntactic processing. Journal of Memory and Language, 25, 348-368.

Ficher, I.V., Zuckerman, M., \& Steinberg, M. (1988). Sensation seeking congruence in couples as a determinant of marital adjustment: a priori replication and extension. Journal of Clinical Psychology, 44, 803-809.

Fink, B., Grammer, K., \& Thornhill, R. (2001). Human (homo sapiens) facial attractiveness in relation to skin texture and color. Journal of Comparative Psychology, 115, 92-99.

Fink, B., Manning, J.T, Neave, N., \& Grammer, K. (2004). Second to fourth digit ratio and facial asymmetry. Evolution and Human Behavior, 25, 125-132.

Fink, B., Neave, N., Grammer, K., \& Manning, J.T. (2006). Facial symmetry and judgements of attractiveness, health and personality. Personality and Individual Differences, 41, 491-499.

Fink, B. \& Penton-Voak, I. (2002). Evolutionary psychology of facial attractiveness. Current Directions in Psychological Science, 11, 154-158.

Fisher, J.A. (2002). Tattooing the body, marking the culture. Body \& Society, 8, 91-107.

Fisher, R. A. (1930). The genetical theory of natural selection. Oxford: Clarendon Press.

Folstad, I. \& Karter, A.J. (1992). Parasites, bright males and the immunocompetence handicap. American Naturalist, 139, 603-622. 
Forbes, G.B. (2001). College students with tattoos and piercings: motives, familiy experiences, personality factors and perception by others. Psychological Reports, 89, 774-796.

Frederick, C.M., \& Bradley, K.A. (2000). A different kind of normal? Psychological and motivational characteristics of young adult tattooers and body piercers. North American Journal of Psychology, 2, 379-391.

Fried, R.I. (1983). The psychodynamics of tattooing: a review. Cleveland Clinical Quarterly, $50,239-242$.

Friederich, M. (1993). Tätowierungen in Deutschland - eine kultursoziologische Untersuchung in der Gegenwart. [Tattoos in Germany - a culture-sociological examination in the present]. Vol. 14, Würzburg.

Frost, P. (1988). Human skin colour: a possible relationship between its sexual dimorphism and its social perception. Perspectives in Biology and Medicine, 32, 38-58.

Gallick, R. (1996). The tattoo: an American pop art form. The Mid-Atlantic Almanac, 5, 1-13.

Gangestad, S.W., \& Scheyd, G.J. (2005). The Evolution of Human Physical Attractiveness. Annual Review of Anthropology, 34, 523-548.

Gangestad, S.W., \& Simpson, J. A. (2000). The evolution of human mating: trade-offs and strategic pluralism. Behavioural and Brain Sciences, 23, 573-644.

Gangestad, S.W., Thornhill, R., \& Garver, C.E. (2002). Changes in women's sexual interests and their partners' mate-retention tactics across the menstrual cycle: evidence for shifting conflicts of interest. Proceedings of the Royal Society of London, Series B, 269, 975-982.

Gans, E. (2000). The body sacrificial. In T. Siebers (Ed.). The body aesthetic: from fine art to body modification. (pp.159-178). University of Michigan Press.

Gathercole, P. (1988). Contexts of Maori Moko. In A. Rubin (Ed). Marks of Civilization. (pp. 171-179). Los Angeles: Museum of Cultural History.

Geary, D.C., Vigil, J., \& Byrd-Craven, J. (2004). Evolution of human mate choice. The Journal of Sex Research, 41, 27-42.

Gilbert, S. (2001). Tattoo history: A source book: Juno books.

Goldberg, L.R. (1990). An alternative "Description of Personality": The Big-Five factor structure. Journal of Personality and Social Psychology, 59, 1216-1229.

Goldberg, D., \& Anderson, E. (2004). Hepatitis C: who is at risk and how do we identify them? Journal of Viral Hepatitis, 11, 12-18.

Govenar, A. (1988). The variable context of Chicano tattooing. In A. Rubin (Ed.) Marks of civilization. (pp.209-219). Los Angeles, Museum of Cultural History, University of California, Los Angeles.

Govenar, A. (2000). The changing image of tattooing in American culture, 1846-1966. In J.Caplan (Ed.). Written on the body: the tattoo in European and American history. Princeton, NJ: Princeton University Press.

Gowaty, P.A. (2004). Sex roles, contests for the control of reproduction, and sexual selection. In: P.M. Kappeler \& C.P. Van Schaik (Eds.). Sexual Selection in primates: new and comparative perspectives. (pp. 37-54). Cambridge: Cambridge University Press.

Grafen, A. (1990). Biological signals as handicaps. Journal of Theoretical Biology, 144, 517 $-546$.

Grammer, K. (2004). Körpersignale in menschlicher Interaktion. [Body signals in human interactions]. In R. Posner, K. Robering, \& A. A. Seboek (Eds.) Semiotik-Semiotics: handbook on the sign - theoretic foundations of nature and culture. (pp. 3448-3487). Vol. 4. Berlin: Walter DeGruyter.

Grammer, K., Fink, B., Møller, A.P., \& Thornhill, R. (2003). Darwinian aesthetics: sexual selection and the biology of beauty. Biological Reviews, 78, 385-407. 
Grammer, K., Renninger, L., \& Fischmann, B. (2004). Disco clothing, female sexual motivation, and relationship status: is she dressed to impress? Journal of Sex Reseach, 41, 66-74.

Graziano, W., Jensen-Campbell, L., Shebilske, L., \& Lundgren, S. (1993). Social influence, sex differences, and judgments of beauty. Journal of Personality and Social Psychology, 65, 522-531.

Greene, H.H., \& Rayner, K. (2001). Eye movements and familiarity effects in visual search. Vision Research, 41, 3763-3773.

Greif, J., Hewitt, W., \& Armstrong, M.L. (1999). Tattooing and body piercing. Clinical Nursing Research, 8, 368-385.

Grieder, T. (1982). Origins of Pre-Columbian Art. Austin: University of Texas Press.

Grindley, G.C., \& Townsend, V. (1968). Voluntary attention in peripheral vision and its effects on acuity and differential thresholds. Quarterly Journal of Experimental Psychology, 20, 1-10.

Gritton, J. (1988). Labrets and tattooing in native Alaska. In A. Rubin (Ed). Marks of Civilization. (pp. 181-191). Los Angeles: Museum of Cultural History.

Grumet, G.W. (1983). Psychodynamic implications of tattoos. American Journal of Orthopsychiatry, 53, 482-492.

Halla, W. (1980). Augenbewegungen: die Wahrnehmung unbekannter Personen. [Eye movement: perception of unfamiliar persons]. Dissertation, University of Vienna, Austria.

Hamilton, W. D., \& Zuk, M. (1982). Heritable true fitness and bright birds: a role of parasites. Science, 218, 384-387.

Hanes, J.M. (2005). Behind steelt doors: images from the walls of a county jail. Art Therapy, 22, 44-48.

Hardy, D. (1989). Don Ed Hardy. In V. Vale \& A. Juno (Eds.) Re/Search \# 12: Modern Primitives. (pp. 50-67). San Francisco: Re/Search Publications.

Hebdige, D. (1979). Subculture, the meaning of style. London: Methuen.

Henderson, J.M. (1999). The effect of semantic consistency on eye movements during complex scene viewing. Journal of Experimental Psychology: Human Perception and Performance, 25, 210-228.

Hewitt, K. (1997). Mutilating the body: identity in blood and ink. Bowling Green, $\mathrm{OH}$ : Bowling Green State University Press.

Hines, M. (2006). Prenatal testosterone and gender-related behaviour. European Journal of Endocrinology, 155, 115-121.

Hines, M., Brook, C., \& Conway, G.S. (2004). Androgen and psychosexual development: core gender identity, sexual orientation and recalled childhood gender role behavior in women and men with congenital adrenal hyperplasia (CAH). Journal of Sex Research, $41,75-81$.

Horvath, T. (1981). Physical attractiveness: The influence of selected torso parameters. Archives of Sexual Behavior, 10, 21-24.

Houghton, S.J., Durkin, K., Parry, E., \& Turbett, (1996). Amateur tattooing practices and beliefs among high school adolescents. Journal of Adolescent Health, 16, 420-425.

Huxley, C., \& Grogan, S. (2005). Tattooing, piercing, healthy behaviours and health value. Journal of Health Psychology, 10, 831-841.

Irwin, K. (2001). Legitimating the first tattoo: moral passage through informal interaction. Symbolic Interaction, 24, 49-73.

Jeffreys, S. (2000). 'Body art' and social status: cutting, tattooing and piercing from a feminist perspective. Feminism \& Psychology, 10, 409-429. 
John, O.P., Donahue, E.M., \& Kentle, R.L. (1991). The Big Five Inventory: Versions 4a and 54. Berkeley: University of California, Berkeley, Institute of Personality and Social Research.

John, O.P., \& Srivastava, S. (1999). The Big Five trait taxonomy: History, measurement, and theoretical perspectives. In L.A. Pervin \& O.P. John (Eds), Handbook of personality: Theory and research ( $2^{\text {nd }}$ ed., pp. 102-138). New York: The Guilford Press.

Johnson, J.M. (1989). Horror stories and the construction of child abuse. In J. Best (Ed.). Images of Issues. (pp.5-20). New York: Aldine de Gruyter.

Johnston, V.S., Hagel, R., Franklin, M., Fink, B., \& Grammer, K. (2001). Male facial attractiveness: evidence for hormone-mediated adaptive design. Evolution and Human Behavior, 22, 251-267.

Jonaitis, A. (1988). Women, marriage, mouths and feasting: the symbolism of Tlingit. In A. Rubin (Ed). Marks of Civilization. (pp. 191-207). Los Angeles: Museum of Cultural History.

Jones, D. (1996). Physical Attractiveness and the Theory of Sexual Selection. Ann Arbor, MI: Museum of Anthropology, University of Michigan.

Jones, B.C., Little, A.C., Feinberg, D.R., Penton-Voak, I.S., Tiddeman, B.P., \& Perret, D.I. (2004). The relationship between shape symmetry and perceived skin condition in male facial attractiveness. Evolution and Human Behavior, 25, 24-30.

Kleese, C. (1999). Modern primitivism: non-mainstream body modification and racialized representation. Body \& Society, 5, 15-38.

Koch, J.R., Roberts, A.E., Armstrong, M., \& Owen, D.C. (2005). College Students, tattoos and sexual activity. Psychological Reports, 97, 887-890.

Kokko, H., \& Monaghan, P. (2001). Predicting the direction of sexual selection. Ecology Letters, 4, 159-165.

Kokko, H., Brooks, R., McNamara, J., and Houston, A. (2002). The sexual selection continuum. Proceedings of the Royal Society London: Biological Sciences, 269, 1331-1340.

Kral, A.H., Bluthenthal, R.N., Lorvick, J., Gee, L., Bacchetti, P., \& Edlin, B.R. (2001). Sexual transmission of HIV-1 among injection drug users in San Francisco, USA: risk-factor analysis. The Lancet, 357, 1397-1401.

Krause, H.-R., Bremerich, A., \& Sztraka, M. (2000). Komplikationen nach Piercing im Mund und im Gesicht. [Medical complications following piercing in mouth and face]. Mund Kiefer GesichtsChir., 4, 21-24.

Lang, F.R., Luedtke, O., \& Asendorpf, J.B. (2001). Testguete und psychometrische Aequivalenz der deutschen Version des Big Five Inventory (BFI) bei jungen, mittelalten und alten Erwachsenen. [Validity and psychometric equivalence of the German adaptation of the Big Five Inventory in young, middle and old adults]. Diagnostica, 47, 111-121.

Langford, R. (1996). The hole truth. Nursing Times, 92, 46-47.

Laumann, A.E., \& Derick, A.J. (2006). Tattoos and body piercings in the United States: A national data set. Journal of the American Academy of Dermatology, 55, 413-421.

Law-Smith, M.J, Perrett, D.I., Jones, B.C., Cornwell, R.E., Moore, F.R., Feinberg, D.R., Boothroyd, L.G., Durrani, S.J., Stirrat, M.R., Whiten, S., Pitman, R.M., \& Hillier, S.G. (2006). Facial appearance is a cue to oestrogen levels in women. Proceedings of the Royal Society of London, Series B, 273, 135-40.

Levine, M.P. (1998). Gay macho: the life and death of the homosexual clone. New York: New York University Press.

Lin, Y. (2002). Age, sex, education, religion, and perception of tattoos. Psychological Reports, 90, 654-658. 
Litle, P., \& Zuckerman, M. (1986). Sensation seeking and music preferences. Personality and Individual Differences, 4, 575-578.

Littell, A.E. (2003). The illustrated self: construction of meaning through tattoo images and their narratives. (unpublished) $\mathrm{PhD}$ thesis, Antioch University, New England Graduate School, USA. Dissertation Abstracts International: Section B: The Sciences \& Engineering, 64, 424.

Loftus, G.R., \& Mackworth, N.H. (1978.) Cognitive determinants of fixation location during picture viewing. Journal of Experimental Psychology: Human Perception and Performance, 4, 565-572.

Long, G.E., \& Rickman, L.S. (1994). Infectious complications of tattoos. Clinical Infectious Diseases. 18, 610-619.

López-Jornet, P., Navarro-Guardiola, C., Camacho-Alsonso, F., Vicente-Ortega, V., \& Yánez-Gascon, J. (2006). Oral and facial piercings: a case series and review of the literature. International Journal of Dermatology, 45, 805-809.

Low, B.S. (1979). Sexual selection and human ornamentation. In N.A. Chagnon \& W. Irons (Eds.). Evolutionary biology and human social behavior. (pp. 462-487) Duxbury Press, Massachusetts.

Ludvico, L.R., \& Kurland, J.A. (1995). Symbolic and not-so symbolic wounds: The behavioural ecology of human scarification. Ethology and Sociobiology, 16, 155-172.

Maisey, D.S., Vale, E.L.E., Cornelissen, P.L., \& Tovée, M.J. (1999). Characteristics of male attractiveness for women. The Lancet, 353, 1500.

Mak, W.M., Vonk, W., \& Shriefers, H. (2002). The influence of animacy on relative clause processing. Journal of Memory and Language, 47, 50-68.

Makkai, T., \& McAllister, I. (2001). Prevalence of tattooing and body piercing in the Australian community. Communicable Diseases Intelligence, 25, 67-72.

Malloy, D. (1989). Body piercings. In V. Vale \& A. Juno (Eds). Re/Search \# 12: Modern primitives (pp.25-26). San Francisco, CA: Re/Search Publications.

Maner, J.K. (2003). Beauty captures in the eye of the beholder: selective attention and physical attractiveness. Dissertation Abstracts International: Section B: The Sciences and Engineering, 64(3B), 1551.

Marcoux, D. (2000). Appearance, cosmetics, and body art in adolescents. Dermatologic Clinics, 18, 667-673.

Mariano, A., Mele, A., Tosti, M.E., Parlato, A., Gallo, G., Ragni, P., Zotti, C., Lopalco, P., Pompa, M.G., Graziani, G. \& Stroffolini, T. (2004). Role of beauty treatment in the spread of parenterally transmitted hepatitis viruses in Italy. Journal of Medical Virology, 74, 216-220.

Maronna, R.A. (1976). Robust M-estimators of multivariate location and scatter. Annals of Statistics, 4, 51-67.

Martin, A. (1997). On teenagers and tattoos. Journal of the American Academy of Child \& Adolescent Psychiatry, 36, 860-861.

Maynard Smith, J., \& Harper, D.G.C. (1995). Animal signals: models and terminology. Journal of Theoretical Biology, 177, 305-311.

Mazur, A., \& Booth, A. (1998). Testosterone and dominance in men. Behavioral and Brain Sciences, 21, 353-363.

Mazur, A., Halpern, C., \& Udry, J.R. (1994). Dominant looking male teenagers copulate earlier. Ethology and Sociobiology, 15, 87-94.

McCallum, D. (1988). Historical and cultural dimensions of the tattoo in Japan. In A. Rubin (Ed.), Marks of Civilization. (pp. 109-134) Los Angeles: Museum of Cultural History.

McGraw, K.J., \& Ardia, D.R. (2003). Carotenoids, immunocompetence, and the information content of sexual colors: an experimental test. American Naturalist, 162, 704-712. 
McGraw, K. J. \& Hill, G. E. (2000). Differential effects of endoparasitism on the expression of carotenoid- and melanin-based ornamental coloration. Proceedings of the Royal Society of London B: Biological Sciences, 267, 1525-1531.

McKinley, N.M. (1999). Woman and objectified body consciousness: Mothers' and daughters' body experience in cultural, developmental, and familial context. Developmental Psychology, 35, 760-769.

Mercury, M. (2001). Pagan fleshworks: a depth psychological study of contemporary body modification. (unpublished) $\mathrm{PhD}$ thesis, Pacifica Graduate School, USA. Dissertation Abstracts International: Section B: The Sciences and Engineering, 62, 1589.

Messerschmidt, J.W. (1993). Masculinities and crime. Lanham, MD: Rowman \& Littlefield.

Mifflin, M. (1997). Bodies of subversion. New York: Juno Books.

Milinski, M., and Bakker, T.C.M. (1990). Female sticklebacks use male coloration in mate choice and hence avoid parasitized males. Nature, 344, 331-333.

Millner, L., \& Edenholm, M., (1999). Genital piercing to enhance sexual satisfaction. Obstetrics and Gynecology, 93, 837.

Millner, V.S., \& Eichold, B.H. (2001). Body piercing and tattooing perspectives. Clinical Nursing Research, 10, 424-441.

Møller, A.P., \& Petrie, M. (2001). Condition dependence, multiple sexual signals, and immunocompetence in peacocks. Behavioral Ecology, 13, 248-253.

Moore, A., Gowaty, P., Wallin, W., \& Moore, P. (2001). Sexual conflict and the evolution of female mate choice and male social dominance. Proceedings of the Royal Society London: Biological Sciences, 268, 517-523.

Morris, D. (1967). The naked ape: A zoologist's study of the human animal. New York: McGraw-Hill.

Morris, D. (1985). Body watching. London: Jonathan Cape.

Mueller, U., \& Mazur, A. (1998). Reproductive constraints on dominance competition in male Homo sapiens. Evolution and Human Behavior, 19, 387-396.

Mulacz, W.P. (1998). Deliberately caused bodily damage (DCBD) phenomena: a different perspective. Journal of the Society for Psychical Research, 62, 434-444.

Murdock, G. P., \& White, D.R. (1969). Standard Cross-Cultural Sample. Ethnology, 8, 329-369.

Musafar, F. (1995). Body Play and Modern Primitves Quarterly, 1, 3.

Musafar, F. (1996). Body play: state of grace or sickness? In A. Favazza (Ed.). Bodies under siege: self-mutilation and body modification in culture and psychiatry. (pp. 325-334) Baltimore, MD: Johns Hopkins University Press.

Myers, J. (1992). Non-mainstream body modification: genital piercing, branding, burning and cutting. Journal of Contemporary Ethnography, 213, 267-306.

Myers, J. (1997). Non-mainstream body modification. In P. Adler \& P. Adler (Eds.), Construction of Deviance. (pp. 516-532). New York: Wadsworth.

Nathanson, C., Paulhus, D.L., \& Williams, K.M. (2006). Personality and misconduct correlates of body modification and other cultural deviance markers. Journal of Research in Personality, 40, 779-802.

Neave, N., Laing, S., Fink, B., \& Manning, J.T. (2003). Second to fourth digit ratio, testosterone, and perceived male dominance. Proceedings of the Royal Society of London, Series B, 270, 2167-2172.

Oliveira, M.D., Matos, M.A., Martins, R.M.B., \& Teles, S.A. (2006). Tattooing and body piercing as lifestyle indicator of risk behaviors in Brazilian adolescents. European Journal of Epidemiology, 27, 559-560.

Packer, C. (1983). Sexual dimorphism: the horns of African antelopes. Science, 221, 1191-1193. 
Palermo, G. B. (2004). Tattooing and tatooed criminals. Journal of Forensic Psychology Practice, 4, 1-25.

Papameletiou, D., Zenié, A., Schwela, D., \& Bäumler, W. (2003). Risks and health effects from tattoos and body piercing and related practices. Ispra.

Penton-Voak, I.S. \& Chen, J.Y. (2004). High salivary testosterone is linked to masculine male facial appearance in humans. Evolution and Human Behaviour, 25, 229-241.

Penton-Voak, I.S., Perrett, D.I., Castles, D., Burt, M., Kobayashi, T., \& Murray, L.K. (1999). Female preferences for males change cyclically. Nature, 399, 741-742.

Perrett, D.I., Lee, K.J., Penton-Voak, I.S., Rowland, D.R., Yokisjawa, S., Burt, D.M., Henzi, S.P., Castles, D.L., \& Akamatsu, S. (1998). Effects of sexual dimorphism on facial attractiveness. Nature, 394, 884-887.

Perusse, D. (1993). Cultural and reproductive success in industrial societies: testing the relationship at the proximate and ultimate levels. Behavioral and Brain Sciences, 16, 267-322.

Petrie, M., \& Halliday, T. (1994). Experimental and natural changes in the peacock's (Pavo cristatus) train can affect mating success. Behavioral Ecology and Sociobiology, 35, 213-217.

Phillip, S.A. (2001). Gallo's body: decoration and damnation in the life of a Chicano gang member. Ethnography, 2, 357-388.

Pierce, C.A., Block, R.A., \& Agiunis, H. (2004). Cautionary note on reporting eta-squared values from multifactor ANOVA designs. Educational and Psychological Measurements, 64, 916-924.

Pitts, V. (1998). 'Reclaiming' the female body: embodied identity work, resistance, and the grotesque. Body \& Society, 4, 67-84.

Pitts, V. (1999). Body modification, self-mutilation and agency in media accounts of a subculture. Body \& Society, 5, 291-303.

Pitts, V. (2003). In the flesh - the cultural politics of body modification. New York: Palgrave Macmillan.

Polhemus, T. (1994). Street style: from sidewalk to catwalk. London, UK: Thames and Hudson.

Polhemus, T., \& Proctor, L. (1978). Fashion and anti-fashion. London: Thames and Hudson.

Posner, M.I. (1980). Orienting of attention. Quarterly Journal of Experimental Psychology, 32, 3-25.

Rayner, K. (1998). Eye movements in reading and information processing: 20 years of research. Psychological Bulletin, 124, 372-422.

Reybold, L. (1996). Everything you need to know about the dangers of tattooing and body piercing. New York: The Rosen Publishing Group Inc.

Reyntjens, K.O. (2002). Psychological variables and personal meanings for women who are tattooed. (unpublished) $\mathrm{PhD}$ thesis, Texas Women's University, USA. Dissertation Abstracts International: Section B: The Sciences \& Engineering, 62, 5977.

Richardson, D.R., Medvin, N., \& Hammock, G. (1988). Love styles, relationship experience, and sensation seeking: a test of validity. Personality and Individual Differences, 9, 645-651.

Riley, S.C.E., \& Cahill, S. (2005). Managing meaning and belonging: young women's negotiation of authenticity in body art. Journal of Youth studies, 8, 261-279.

Roberti, J.W., Storch, E.A., \& Bravata, E. (2004). Sensation seeking, exposure to psychosocial stressors, and body modifications in a college population. Personality and Individual Differences, 37, 167-1177.

Roberts, A.F. (1988). Tabwa tegumentary inscription. In A. Rubin (Ed.), Marks of Civilization. (pp. 41-56) Los Angeles: Museum of Cultural History. 
Roberts, S.C., Little, A.C., Gossling, M., Perrett, D.I., Carter, V., Jones, B.C., Penton-Voak, I.S., \& Petrie, M. (2005). MHC-heterozygosity and human facial attractiveness. Evolution and Human Behavior, 26, 213-226.

Roberts, T.A., Aulinger, P., \& Ryan, S.A. (2004). Body piercing and high-risk behavior in adolescents. Journal of Adolescent Health, 34, 224-229.

Roberts, T.A., \& Ryan, S.A. (2002). Tattooing and high-risk behavior in adolescents. Pediatrics, 110, 1058-1063.

Robinson, J. (1998). The quest for human beauty: an illustrated history. New York: W.W. Norton and Company.

Romans, S.E., Martin, J.L., Morris, A.M., \& Harrison, K. (1998). Tattoos, childhood sexual abuse and adult psychiatric disorder in women. Archives of Women's Mental Health, $1,137-141$.

Rosenblatt, D. (1997). The antisocial skin: structure, resistance, and 'modern primitive' adornment in the United States. Cultural Anthropology, 12, 287-334.

Rubin, A. (1988a). Marks of Civilization. Los Angeles: Museum of Cultural History.

Rubin, A. (1988b). The tattoo renaissance. In A. Rubin (Ed.), Marks of Civilization. (pp. 233-265). Los Angeles: Museum of Cultural History.

Rubio, R.P. (2003). Natives of a new skinscape: tattoos as cultural coding. (unpublished) PhD thesis, Pacifica Graduate Institute, USA. Dissertation Abstracts International: Section A: Humanity \& Social Sciences, 63, 2603.

Russell, R. (2003). Sex, beauty, and the relative luminance of facial features. Perception, 32, 1093-1107.

Sadalla, E., Kenrick, D., \& Vershure, B. (1987). Dominance and heterosexual attraction. Journal of Personality and Social Psychology, 52, 730-738.

Saino, N., Bolzern, A.M., Møller A.P. (1997). Immunocompetence, ornamentation, and viability of male barn swallows (Hirundo rustica). Proceedings of the National Academy of Sciences, 94, 549-52.

Saino, N., Ferrari, R.P., Romano, M., Rubolini, D., Møller, A.P. (2003). Humoral immune response in relation to senescence, sex and sexual ornamentation in the barn swallow (Hirundo rustica). Journal of Evolutionary Biology, 16, 1127-34.

Sanders, C.R. (1988). Marks of mischief: becoming and being tattooed. Journal of Contemporary Ethnography, 16, 395-432.

Sanders, C.R. (1989). Customizing the body: the art and culture of tattooing. Philadelphia: Temple University Press.

Sanders, C.R. (1991). Memorial decoration: women, tattooing, and the meanings of body alteration. Michigan Quarterly Review, 30, 146-157.

Sarnecki, J. (2001). Trauma and tattoo. Anthropology of Consciousness, 12, 35-42.

Satchithananda, D. K., Walsh, J., \& Schofield, P. M. (2001). Bacterial endocarditis following repeated tattooing. Heart, 85, 11-12.

Scheib, J.E. (2001). Context-specific mate choice criteria: women's trade-offs in the contexts of long-term and extra-pair mating. Personal Relationships, 8, 371-389.

Schierman, M.J., \& Rowland, G.L. (1985). Sensation seeking and selection of entertainment. Personality and Individual Differences, 5, 599-603.

Schildkrout, E. (2004). Inscribing the body. Annual Review of Anthropology, 33, 319-344.

Schmitt, D.P. (2005). Sociosexuality from Argentina to Zimbabwe: A 48-nation study of sex, culture, and strategies of human mating. Behavioral and Brain Sciences, 28, 247-275.

Schneider-Dueker, M., \& Kohler, A. (1988). Die Erfassung von Geschlechtsrollen Ergebnisse zur deutschen Neukonstruktion des Bem Sex-Role-Inventory. [Assessment of sex roles - results of a German adaptation of the Bem Sex Role Inventory]. Diagnostica, 256-270. 
Schönefeld, W. (1960). Körperbemalungen. Brandmarken, Tätowieren. Heidelberg.

Schrader, A.M. (2000). Branding the other / tattooing the self: bodily inscription among convicts in Russia and the Soviet Union. In Caplan, J. (Ed.). Written on the body: the tattoo in European and American history. (pp 174-192). Princeton, NJ: Princeton University Press.

Seiter, J.S., \& Hatch, S. (2005). Effect of tattoos on perceptions of credibility and attractiveness. Psychological Reports, 96, 1113-1120.

Service, R. (1998). New role of estrogen in cancer. Science, 279, 1631-1632.

Sheppard, J.A., \& Kwavnick, K.D. (1999). Maladaptive image maintenance. In R. Kowlasi \& M. Leary (Eds.). The social psychology of emotional and behavioral problems: Interfaces of social and clinical psychology (pp. 249-277). Washington, DC: American Psychological Association.

Shilling, C. (1993). The body and social theory. London: Sage.

Siebers, T. (2000). The body aesthetic - from fine art to body modification. Michigan: University of Michigan Press.

Simpson, J.A. (1998). Sociosexual Orientation Inventory. In W.L.Y.C.M. Davis, R. Bauseman, G. Schreer, \& S.L. Davis (Eds.), Handbook of sexuality-related measures. (pp. 565-567). Thousand Oaks, CA: Sage.

Simpson, J.A., \& Gangestad, S.W. (1991). Individual differences in sociosexuality: Evidence for convergent and discriminant validity. Journal of Personality and Social Psychology, 60, 870-883.

Singh, D. (1993). Adaptive significance of female physical attractiveness: role of waist-to-hip ratio. Journal of Personality and Social Psychology, 65, 293-307.

Singh, D., \& Bronstad, P.M. (1997). Sex differences in the anatomical locations of human body scarification and tattooing as a function of pathogen prevalence. Evolution and Human Behavior, 18, 403-416.

Singh, D., \& Young, R. K. (1995). Body weight, waist-to-hip ratio, breasts, and hips: Role in judgments of female attractiveness and desirability for relationships. Ethology and Sociobiology, 16, 483-507.

Skegg, K., Nada-Raja, S., Paul, C., \& Skegg, D.C.G. (2007). Body piercings, Personality, and Sexual Behavior. Archives of Sexual Behavior, 36, 47-54.

Snowdon, C.T. (2004). Sexual selection and communication. In P.M. Kappeler \& P. Van Schaik (Eds.) Sexual Selection in primates: new and comparative perspectives. (pp. 57-70). Cambridge: Cambridge University Press.

Sokal, R.R., \& Rohlf, J.F. (1981). Analysis of frequencies. In R.R. Sokal \& J.F. Rohlf (Eds.) Biometry ( $2^{\text {nd }}$ edition, pp. 691-767). Freeman and Company.

Solso, R.L. (1999). Cognition and the visual arts. ( $3^{\text {rd }}$ ed.). Cambridge, MA: The MIT Press.

Soyland, J. (1997). Speaking the decorated body. In L. Yardley (Ed.). Material discourses of health and illness. (pp.217-231). New York: Routledge.

Steele, V. (1996). Fetish: fashion, sex and power. New York and Oxford: Oxford University Press.

Steward, S.M. (1990). Bad boys and tough tattoos: a social history of the tattoo with gangs, sailors, and street-corner punks. (pp. 1950-1965). Binghamton, NY, London: Harrington Park / Haworth.

Stirn, A. (2001). Vom Initiationsritual zur geschmückten Haut - Tätowierung im Spiegel von Stammestraditionen und neuem Kunstverständnis. [From ritual initiation to the decorated skin: tattoo as mirrored by tribal traditions and a new perception of art]. Psychotherapie und Sozialwissenschaften, 3/4, 283-305. 
Stirn, A. (2002). Trauma und Tattoo - Piercing, Tätowierung und verwandte Formen der Körpermodifikation zwischen Selbstfürsorge und Selbstzerstörung bei traumatisierten Menschen. [Trauma and tattoo - piercing, tattooing and related forms of body modification between self-care and self-destruction of traumatized individuals]. Psychotraumatologie, 2, 45.

Stirn, A. (2003a). Body piercing: medical consequences and psychological motivations. The Lancet, 361, 1205-1215.

Stirn, A. (2003b). Kunstvolles Tätowieren und Piercing als selbstfürsorgliche Handlung traumatisierter Menschen. [Artistic tattooing and piercing as self-caring act of traumatized people]. Psychoanalyse - Texte zur Sozialforschung, 12, 48-59.

Stirn, A. (2004a). Motivationen von Tätowierten und Gepiercten für ihre Körpermodifikationen. [Motivations of tattooed and pierced for their body modifications]. Zeitschrift für Klinische Psychologie, Psychiatrie und Psychotherapie, 51, 43-58.

Stirn, A. (2004b). Die Selbstgestaltung des Körpers - narzistische Aspekte von Tattoo und Piercing. [Designing the own body - narcissistic aspects of tattoos and piercings]. Psychotherapie im Dialog, 3, 256-260.

Stirn, A., Hinz, A., \& Brähler, E. (2006). Prevalence of tattooing and body piercing in Germany and perception of health, mental disorders, and sensation seeking among tattooed and body-pierced individuals. Journal of Psychosomatic Research, 60, 531-534.

Strauß, B., \& Appelt, H. (1983). Ein Fragebogen zur Beurteilung des eigenen Körpers. [A Questionnaire on the Perception of one's Own Body]. Diagnostica, 29, 145-164.

Strauß, B., \& Richter-Appelt, H. (1996). Fragebogen zur Beurteilung des eigenen Körpers $(F B e K)$. [Questionnaire on the Perception of one's Own Body]. Göttingen: Hogrefe.

Strong, M. (1998). A bright red scream: self-mutilation and the language of pain. New York: Viking.

Stuppy, D.J., Armstrong, M.L., \& Casals-Ariet, C. (1998). Attitudes of health care providers and students towards tattooed people. Journal of Advanced Nursing, 27, 1165-1170.

Sweeney, S.M. (2006). Tattoos: a review of tattoo practices and potetnial treatment options for removal. Current Options in Pediatrics, 18, 391-395.

Sweetman, P. (1999). Anchoring the (postmodern) self? Body modification, fashion and identity. Body and Society, 5, 51-76.

Symons, D. (1979). The Evolution of Human Sexuality. Oxford: Oxford University Press.

Taylor, M.C. (1997). Hiding. Chicago, IL: University of Chicago Press.

Thornhill, R., \& Gangestad, S.W. (1993). Human facial beauty: averageness, symmetry, and parasite resistance. Human Nature, 4, 237-269.

Thornhill, R., \& Gangestad, S.W. (1999). Facial attractiveness. Trends in Cognitive Sciences, 3, 452-460.

Thornhill, R., \& Grammer, K. (1999). The body and face of woman: one ornament that signals quality? Evolution and Human Behavior, 20, 105-120.

Thornhill, R., \& Møller, A.P. (1997). Developmental stability, disease and medicine. Biological Review, 72, 497-548.

Tiggemann, M., \& Golder, F. (2006). Tattooing: An expression of uniqueness in the appearance domain. Body Image, 3, 309-315.

Townsend, J. (1993). Gender differences in mate preferences among law students. Journal of Psychology, 127, 507-528.

Townsend, J.M., \& Wasserman, T. (1997). The perception of sexual attractiveness: sex differences in variability. Archives of Sexual Behavior, 26, 243-267. 
Trivers, R. L. (1972). Parental investment and sexual selection. In B. Campbell (Ed.). Sexual Selection and the Descent of Man 1871-1971. (pp. 136-179). Chicago, Aldine.

Tsuruta, D., Sowa, J., Higashi, N., Kobayashi, H., \& Ishii, M. (2004). A red tattoo and a swordfish supper. The Lancet, 364, 730.

Turner, B.S. (1999). The possibilities of primitiveness: towards a sociology of body marks in cool societies. Body and Society, 5, 39-50.

Vail, D.A. (1999). Tattoos are like potato chips ... you can't have just one: the process of becoming and being a collector. Deviant Behavior, 20, 253-273.

Vale, V., \& Juno, A. (1989). Modern primitives: an investigation of contemporary adornment and ritual. San Francisco: Re/Search Publications.

Van den Berghe, P.L., \& Frost, P. (1986). Skin colour preference, sexual dimorphism and sexual selection: a case of gene-culture co-evolution? Ethnic and Racial Studies, 9, 87-118.

Van Valen, L. (1962). A study of fluctuating asymmetry. Evolution, 16, 125-142.

Varma, S., \& Lanigan, S.W. (1999). Reasons for requesting laser removal of unwanted tattoos. British Journal of Dermatology, 140, 483-485.

Voland, E. \& Grammer, K. (2003). Evolutionary aesthetics. Berlin, Heidelberg, New York: Springer.

Von Helmholtz, H. (1925). Handbuch der Physiologischen Optik [Treatise on physiological optics]. ( $3^{\text {rd }}$ ed.). Rochester, NY: The Optical Society of America.

Wilbert, J. (1994). South America. (Vol. 7). New York: Hall.

Wilson, R.E. (1996). Care of burn patient. Ostomy / Wound Management, 42, 16-26.

Wilson, M. \& Daly, M. (1985). Competiveness, risk taking, and violence: The young male syndrome. Ethology \& Sociobiology, 6, 59-73.

Winchel, R.M., \& Stanley, M. (1991). Self-injurious behavior: A review of the behavior and biology of self-mutilation. American Journal of Psychiatry, 148, 306-317.

Wocjik, D. (1995). Punk and neo-tribal body art. Jackson: University Press of Mississippi.

Wohlrab, S., Fink, B., \& Kappeler, P.M. (2005). Menschlicher Körperschmuck aus evolutionärer Perspektive - Diversität und Funktion von Tätowierungen, Piercings und Skarifizierungen. [Human body ornaments from an evolutionary perspective diversity and function of tattoos, piercings and scarifications]. Mitteilungen der Anthropologischen Gesellschaft Wien, 134/135, 1-10.

Wohlrab, S., Fink, B., Kappeler, P.M., \& Brewer, G. (submitted,a). Differences in personality attributions towards tattooed and non-tattooed virtual human characters.

Wohlrab, S., Fink, B., Kappeler, P.M., \& Brewer, G. (submitted,b). Human body modification: testing the signaling quality of tattoos.

Wohlrab, S., Fink, B., Pyritz, L.W., Rahlfs, M., \& Kappeler, P.M. (2007). Visual attention to plain and ornamented human bodies: an eye-tracking study. Perceptual and Motor Skills, 104, 1337-1349.

Wohlrab, S., Stahl, J., \& Kappeler, P.M. (2007). Modifying the body: Motivations for getting tattooed and pierced. Body Image, 4, 87-95.

Wohlrab, S., Stahl, J., Rammsayer, T., \& Kappeler, P.M. (in press). Differences in personality characteristics between body modified and non-modified individuals and possible evolutionary implications. European Journal of Personality.

Wright, J. (1995). Modifying the body: piercing and tattoos. Nursing Standard, 10, 27-30.

Yarbus, A. L. (1967). Eye movements and vision. New York, NY: Plenum.

Zahavi, A. (1975). Mate selection - a selection for a handicap. Journal of Theoretical Biology, 53, 205-214.

Zahavi A. (1977). The cost of honesty (further remarks on the handicap principle). Journal of Theoretical Biology, 67, 603-605. 
Zuckerman, M. (1979). Sensation Seeking. Beyond the optimal level of arousal. Hillsdale, NJ: Erlbaum.

Zuckerman, M. (1983). Sensation Seeking and sports. Personality and Individual Differences, 4, 285-293.

Zuckerman, M. (1984). The neurobiology of some dimensions of personality. In J.R. Smythies \& R. J. Bradley (Eds.), International review of neurobiology, 25, 329-436.

Zuckerman, M. (1994). Behavioral expressions and biosocial bases of sensation seeking. Cambridge: Cambridge University Press.

Zuckerman, M., Bone, R.N., Neary, R., Mangelsdorff, D., \& Brustman, B. (1972). What is the sensation seeker? Personality trait and experience correlates of the Sensation Seeking Scales. Journal of Consulting and Clinical Psychology, 39, 308-321.

Zuckerman, M., Eysenck, S., \& Eysenck, H.J. (1978). Demographic influences in sensation seeking and expressions of sensation seeking in religion, smoking and driving habits. Personality and Individual Differences, 1, 197-206.

Zuckerman, M., \& Litle, P. (1986). Personality and curiosity about morbid and sexual events. Personality and Individual Differences, 7, 49-56.

Zuckerman, M., Tushup, R., \& Finner, S. (1976). Sexual attitudes and experience: Attitudes and personality correlates and changes produced by a course in sexuality. Journal of Consulting and Clinical Psychology, 44, 7-19.

Zuk, M. (1991). Sexual ornaments as animal signals. Trends in Ecology and Evolution, 6, $228-231$. 
Silke Wohlrab

Wiesenbach 77

33611 Bielefeld

0521894528

01745155334

swohlra@gwdg.de

Geburtsdatum, -ort

31.10.1976, Ingolstadt

Familienstand

ledig

Staatsangehörigkeit

deutsch

\section{AUSBILDUNG}

Seit $01 / 2004$

$07 / 2002-7 / 2003$

04/2000-07/2003

10/1997-03/2000

06/1996

08/1987-06/1996
Promotion an der Universität Göttingen

Abteilung Soziobiologie / Anthropologie

Doktorvater: Prof. Dr. Peter Kappeler

Diplom, Biologie

Gesamtnote: Mit Auszeichnung

Diplomarbeit am Long Marine Laboratory, California, USA:

'Prey handling behavior in sea otters'

Hauptstudium der Biologie, Universität Bielefeld

Studienschwerpunkte: Verhaltensökologie, Neuroethologie

Grundstudium der Biologie, Universität Regensburg Studienschwerpunkte:

Mikrobiologie, Biochemie, Genetik

Abitur

Christoph-Scheiner-Gymnasium Ingolstadt

BERUFLICHE TÄTIGKEITEN

04/2007

01/2004-03/2006
Pharmareferent

Firma Innovex

Wissenschaftliche Hilfskraft, Universität Göttingen

Arbeitsgruppe Humanethologie

Entwicklung, Planung und Durchführung von Experimenten; Rekrutierung und Betreuung von Probanden; Betreuung von Studenten; Öffentlichkeitsarbeit und PR; Aufbau und Wartung von Messgeräten 